\title{
LIFE IN THE ADMINISTRATIVE TRACK: ADMINISTRATIVE ADJUDICATION OF CLAIMS AGAINST SAVINGS INSTITUTION RECEIVERSHIPS
}

\author{
LAWRENCE G. BAXTER*
}

INTRODUCTION ....................................

I. EMERGENCE OF THE HUDSPETH DOCTRINE ........... 430

A. Thrifts and the Banking Industry ............... 430

B. Development and Structure of the Regulatory Framework............................... 432

C. Transformation of the Thrift Industry .............. 434

D. Escalation of Thrift Failures and Depletion of the FSLIC's Insurance Fund ...................... 436

E. Reaction and Adaptation at the FHLBB ............ 439

F. Conflict in the Courts ......................... 440

1. Hudspeth: The "Administrative Track" .......... 441

2. Morrison-Knudsen: No Statutory Authority ....... 445

3. Glen Ridge: $A$ Violation of Article III ........... 447

4. Other Constitutional Issues ................... 449

II. The Liquidation Process ...................... 450

A. Options for Dealing with Troubled Thrifts ........... 450

1. Sales and Financial Assistance ................. 450

2. Receivership .......................... 451

3. Federal Asset Disposition Association ............ 451

* Professor of Law, Duke University. B.Comm. 1973, LL.B. 1975, Ph.D. 1985, University of Natal; LL.B. 1977, Dip. Legal Studs., 1978 Cambridge University. This article is a shightly modified and updated version of a report subnitted to the Administrative Conference of the United States. The views do not necessarily reflect those of the Conference, its committees, or its staff, and the author is solely responsible for its contents.

The author is grateful to a large number of persons for their generons time, assistance, and advice, and he wishes to acknowledge the following persons in particular: Bruce A. Cohen, Sarah $\mathbf{H}$. Comley, Wylene W. Dunbar, David A. Felt, Judith L. Friednian, Mark Gabrellian, Robert E. Goodfriend, Arthur W. Leibold, Jeffrey S. Lubbers, Brian C. Murphy, Thomas A. Pfeiler, Reuben B. Robertson, Thonias D. Rowe, Jr., the niembers of the Financial Services Committee of the Conference, and his research assistants, Carla S. Cancio-Bello, Jonathan M. Crotty, Carlotta L. Martin, and Ioannis Tassopoulos. Journal.

Copies of all unpublished sources cited in this article are on file in the offices of the Duke Law 
B. Placing Thrifts into Receivership................ 452

1. The Agencies Involved ..................... 452

2. Power to Appoint Receivers .................. 452

a. Federally chartered thrifts................. 452

b. State-chartered thrifts................... 453

c. Exclusivity of the FHLBB's power of appointment and removal ................... 453

3. Powers Upon Appointment ................... 454

a. Powers conferred by statute ................. 454

b. The Board's regulatory powers............... 456

4. Strategies Developed by the FSLIC............. 456

5. Claims Procedures ........................... 457

C. Depositor Claims ............................. 459

1. Notice to Potential Claimants .................. 459

2. Initial Determinations ...................... 459

3. Insurance Appeals ("Reconsiderations") ......... 460

4. Judicial Review ............................ 460

D. Uninsured and Nondepositor Claims: The Hudspeth Process ...................................... 461

1. Types of Claims Involved ..................... 461

a. Claims filed prior to receivership ............ 462

b. Claims adjudicated prior to receivership ....... 462

c. Post-receivership litigation .................. 462

d. Claims against the exercise of receivership powers 463

2. Structures and Procedures Developed by the FHLBB 464

a. Internal receivership arrangements ............ 464

b. Notice to potential claimants ................. 465

c. Determinations by the receiver ............... 466

d. Administrative reviews ...................... 469

e. Board review ............................ 470

f. Judicial review .......................... 470

3. "Expedited Relief" ........................ 471

E. Overview of the Adjudicatory Structure ............. 472

III. Constraints Upon Agency Adjudication ........... 473

A. Legislative Constraints: The Authority to Adjudicate ... 474

1. Statutory Interpretation in Modern Administrative Law .................................. 474

2. Sections $1464(d)(6)(C), 1464(d)(11)$ and 1729(d): History, Context and Application ............... 476

a. Early practices ........................ 477

b. Inception of federal regulation and deposit insurance 
c. Introduction of section $1729(d)$.............. 481

d. Judicial determination of disputed insurance claims ................................. 483

e. Introduction of section $1464(d)(6)(C) \ldots \ldots \ldots . .484$

f. Introduction of section 1464(d)(11) ........... 486

g. Extension of receivership appointment powers .... 486

h. Modification of section $1729(d)$............... 487

i. The irrelevance of sections $1464(d)(\sigma)(C)$ and $1729(d) \ldots \ldots \ldots \ldots \ldots \ldots \ldots \ldots \ldots \ldots . \ldots . \ldots 48$

j. Section 1464(d)(11) as the best basis for the Hudspeth scheme ......................... 489

3. FDIC and NCUAB Analogues ................ 489

a. The FDIC ............................. 489

b. The NCUAB ........................... 493

4. Application of the APA ..................... 497

a. Adjudicatory procedure .................... 498

b. Judicial review ............................ 499

B. Constitutional Constraints ..................... 501

1. Constitutionalism in the Administrative State ...... 501

2. The Network of Constraints ................. 502

a. Delegation of powers ..................... 502

b. Article III............................. 505

(i) The evolution of an article III balancing test .............................. 506

(ii) Implications for the Hudspeth procedures .. 511

c. Due process ............................. 512

(i) Adequacy of the hearing ................ 514

(ii) Impartiality......................... 515

d. Seventh amendment ...................... 518

(i) Supreme Court toleration ............... 519

(ii) Equitable nature of the proceedings ....... 520

3. The Importance of Clear Statutory Authority,

Standards, Internal Separation of Powers,

Procedural Fairness and Adequate Judicial Scrutiny 521

IV. Evaluation of The Hudspeth Process ............... 523

A. Fairness and Flexibility ...................... 524

1. "Receiver's Determinations" .................... 525

2. Administrative Adjudications ("Reviews") ........ 526

B. Efficiency and Cost ........................... 529

1. The Receivership Level ..................... 529

2. The Board Level ......................... 531

3. Previously Adjudicated Claims ............... 531 
C. Judicial Review.............................. 532

D. Procedural Rules ............................ 533

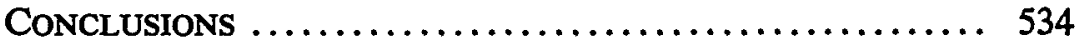

A. Recommendations ........................ 535

1. Acquisition of Statutory Authority for Claims

Adjudication ............................. 535

2. Formalization of the Adjudicative Process......... 535

3. Procedures for Alternative Dispute Resolution...... 536

4. Procedural Rules ......................... 536

5. Jurisdiction over Claims Already Adjudicated in Court ...................................... 536

6. Judicial Review ............................. 536

B. General Observations......................... 537

\section{INTRODUCTION}

In the modern financial services imdustry, thrifts ${ }^{1}$ engage in an unprecedented range of complex and risky commercial transactions. Consequently, the receiver of a failed thrift, which in most cases is the Federal Savings and Loan Insurance Corporation (FSLIC) appointed by the Federal Home Loan Bank Board (FHLBB), ${ }^{2}$ is likely to face a host of complex claims. These claims arise not only from the thrift's deposit liabilities but also from its investment transactions and the incidental disputes generated by such activities. The scene of a thrift failure is often already strewn with litigation, and the receivership itself is likely to generate still more. ${ }^{3}$ Even if higation has not yet commenced, the receiver has to pay the thrift's valid credit obhigations and so has to distinguish good claims from bad and quantify the former. In the process of accepting, settling or rejecting a diverse and complex range of creditor claims, disputes concerning their validity will have to be resolved informally or, if this cannot be done, either through the judicial process or by administrative adjudication. The latter process is the subject of this study.

The importance of this claims determination process has grown with the escalation of thrift failures in recent years. ${ }^{4}$ Although, with the assistance of the FSLIC, many insolvent thrifts can be restored to finan-

1. "Thrift" is used throughout this article to refer to federally chartered and state-chartered, federally insured building associations, savings and loan associations and savings banks. See infra notes 26-39 and accompanying text.

2. For a general discussion of the power to appoint receivers, see infra notes 165-75 and accompanying text.

3. See infra notes $228-43$ and accompanying text.

4. See infra notes 77-87 and accompanying text. 
cial health, sold or merged, a significant number have already proven so irretrievable that the FHLBB has lad to place them into liquidation. As of July 1,1988 , the FSLIC was administering 84 liquidating receiverships involving $\$ 8.2$ billion in receivership assets and considerably more in uninsured creditor claims. ${ }^{5}$ Insofar as they help to avoid litigation, the claims determination procedures employed by the receiver are very important in expediting and reducing the cost of thrift liquidations. On the otlier hand, these procedures have to satisfy conflicting considerations. They must be capable of processing claims efficiently and resolving disputes between creditors and receivers. They should also reinain fair to both parties and they must, of course, rest upon a sound legal foundation.

The FHLBB and the FSLIC have asserted exclusive jurisdiction to adjudicate claims against thrift receiverships. These agencies argue that their clains determinations are subject not to independent, de novo judicial deterinination, but only to the limited judicial review provided under the federal Administrative Procedure Act (APA). ${ }^{6}$ This view has become known as the "Hudspeth doctrine," after the Fifth Circuit decision in which it was first accepted. ${ }^{7}$ Yet, because of the enorinous adjudicatory power that the Hudspeth doctrine concedes to these agencies, the doctrine lias provoked controversy concerning the quality, fairness and efficacy, as well as the legal and constitutional validity, of the agencies' procedures. Although Hudspeth lias been reaffirmed many times by the Fifth Circuit, and lias attracted a large following in the district courts and some state courts, ${ }^{8}$ the Ninth Circuit has refused to follow it, holding that the FSLIC has no statutory authority to adjudicate claims to the preclusion of the courts. ${ }^{9}$ The Texas Supreine Court las taken the saine view in affirming the decision of a state court of appeals that had ruled that the FSLIC has indeed been granted adjudicative authority by statute but that this authority is unconstitutional. ${ }^{10}$ The plethora of conflicting

5. Telephone interview with Judith L. Friedman, Associate General Counsel, FHLBB (Aug. 29, 1988). As of December 31, 1986 (the most recent date for which figures are available), creditor claims already exceeded \$8 billion. 1986 FHLBB ANN. REP. 27-35 (1987).

6. 5 U.S.C. $\$ 706$ (1982) (scope of judicial review for agency action); see infra text accompanying notes 498-509.

7. North Miss. Sav. \& Loan Ass'11 v. Hudspeth, 756 F.2d 1096 (5th Cir. 1985), cert denied, 474 U.S. 1054 (1986). For a discussion of Hudspeth, see infra notes $98-117$ and accompanying text.

8. See infra notes $118-20$ and accompanying text.

9. See Morrison-Knudsen Co. v. CHG Int'1, Inc., 811 F.2d 1209, 1212 (9th Cir. 1987), petition for cert. filed sub nom. FSLIC v. Stevenson Assocs., 56 U.S.L.W. 3249 (U.S. Sept. 17, 1987) (No. 87451); see infra notes 124-31 and accompanying text.

10. See FSLIC v. Glen Ridge I Condominiums, Ltd., 750 S.W.2d 757, 759 (Tex, 1988) (per curiam), aff'g 734 S.W.2d 374 (Tex. Ct. App. 1986) (discussed infra at notes $135-40$ and accompanying text). 
decisions has produced an unusual situation in which two circuits-the Fifth and the Ninth-are in direct conflict, ${ }^{11}$ a third-the Seventh-is somewhat equivocal, ${ }^{12}$ state courts within the territorial jurisdiction of the Fifth Circuit have either followed the ruling of the Ninth Circuit ${ }^{13}$ or gone even further, ${ }^{14}$ and state courts within the territorial jurisdiction of the Ninth Circuit have followed the Fifth Circuit, ${ }^{15}$ while district courts within the territorial jurisdiction of the Seventh Circuit have gone in opposite directions. ${ }^{16}$

This riotous state of affairs will be partly resolved this Term by the Supreine Court. Of four petitions for certiorari that have now been filed, the Court has chosen to hear the one-Coit Independence Joint Venture v. FirstSouth, F.A. ${ }^{17}$ - that is couched in the broadest terms; ${ }^{18}$ the out-

11. See supra notes 7-9 and accompanying text.

12. See Lyons Sav. \& Loan Ass'n v. Westside Bancorporation, 828 F.2d 387 (7th Cir. 1987) (discussed infra at note 134). The decision in Lyons elicited a comment from District Judge Roszkowski that the Seventh Circuit is "never one to rush in where angels fear to tread." Homestead Sav. v. Life Sav. \& Loan Ass'n, 668 F. Supp. 1121, 1124 (N.D. Ill. 1987) (opinion vacated and removed from bound volume, but appears in West's advance slieets, see infra notes 738-39 and accompanying text).

13. See Glen Ridge I, 750 S.W.2d at 759; Summertrec Venture III v. FSLIC, 742 S.W.2d 446, 453 (Tex. Ct. App. 1987).

14. See Glen Ridge I Condominiums, Ltd. v. FSLIC, 734 S.W.2d 374, 386 (Tex. Ct. App. 1986) (holding statutory grant of adjudicative authority to FSLIC unconstitutional), aff'd on other grounds, 750 S.W.2d 757 (Tex. 1988) (per curiam); supra note 10 and accompanying text.

15. See Modern Supply Co. v. FSLIC, 50 Wash. App. 194, 748 P.2d 251 (1987) (split decision); FSLIC v. Superior Court, 180 Cal. App. 3d 336, 225 Cal. Rptr. 422 (1986).

16. See Homestead Sav., 668 F. Supp. at 1121. Contra Rigali v. Life Sav. \& Loan Ass'n of Am., No. 87-C-2543 (N.D. Ill. June 16, 1987) (Westlaw, 1987 WL 12677).

17. 829 F.2d 563 (5th Cir. 1987), cert. granted sub nom. Coit Independence Joint Venture v. FSLIC, 108 S. Ct. 1105 (1988).

18. The questions presented place in issue (i) the statutory authority of the FSLIC as receiver to adjudicate state-law causes of action asserted against failed thrifts; (ii) the acceptability of sucl a sclieme under article III of the Constitution; (iii) the compatibility of such a sclieme with the due process clause; and (iv) whether the scheme violates the seventli amendment right to a jury trial. See Petition for Writ of Certiorari to the United States Court of Appeals for the Fifth Circuit at i, Coit Independence Joint Venture v. FSLIC, 108 S. Ct. 1105 (1987) (No. 87-996).

A number of briefs lave been filed in the Coit appeal. For those supporting the petitioner, see Brief for Petitioner; Petitioner's Reply Brief; Brief Amicus Curiae of Joseph M. Hudspeth in Support of Petitioner; Brief of Amicus Curiae United States League of Savings Institutions in Support of Petitioner; Brief Amicus Curiae of George S. Watson, A. Starke Taylor III and Watson \& Taylor Realty Company in Support of Petitioner. For those supporting the FHLBB and the FSLIC, see Brief for the Respondent; Motion of the Federal Home Loan Bank of Dallas, Federal Honie Loan Bank of San Francisco, and Federal Hone Loan Bank of Topeka for leave to file Brief as Amici Curiae and Brief as Amici Curiae Supporting Affirmance; Brief of Amicus Curiae National Council of Savings Institutions in Support of Respondent. It is interesting to note the opposition of the two major thrift lobbies. Most surprising is the respondent's brief filed by the Solicitor General: notwithstanding the favorable liolding in Hudspeth, the position consistently nuaintained by the FSLIC in subsequent litigation, and the FHLBB's publication of rules establishing an adjudicative process, the respondent's brief disavows any statutory authority on the part of the FSLIC to "adjudicate" claims and argues only that creditors are mandatorily required to exhaust the adninistrative 
come of this case will have an automatic effect on the others. ${ }^{19}$ Meanwhile, the pending uncertainty makes it difficult to provide a coherent administrative law evaluation of the Hudspeth procedures, since they might not be constitutionally valid at all.

Yet it is unlikely that the Supreme Court's decision will be entirely dispositive. Its jurisprudence in the constitutional areas traversed by Coit Independence has become overtly pragmatic. ${ }^{20}$ This suggests that, even where the Court is disposed to find a particular administrative scheme unconstitutional, there might be other ways of devising a scheme that would be constitutional. The Court is unlikely to declare unequivocally that creditor claims require primary adjudication by full-fledged article III courts alone. ${ }^{21}$ To the extent that the FHLBB's desire to avoid routine judicial resolution is dictated by severe financial and organizational constraints, ${ }^{22}$ the Board will probably still want to devise a primary administrative adjudication scheme that is acceptable from the constitutional and administrative law points of view. Coit Independence can provide guidance only as to the outer constitutional constraints on any such scheme. And if, as is possible, the Court declares that the FHLBB inerely lacks present statutory authority, ${ }^{23}$ the FHLBB still has the option of seeking such authority from Congress. On the other hand, even if the Court rules that the FHLBB does have statutory authority and that this authority is constitutionally valid, many issues regarding the fairness and efficiency of the adjudicative process imiplemented by the Board are likely to remain in controversy. The fundamental question, then, of what would constitute a fair administrative procedure for adjudi-

claims process before resorting to the courts. Presumably this leaves it open for claimants to assert the right to de novo review after exhaustion of their administrative remedies. The amici briefs filed in support, on the other hand, adopt more fully the position of the FHLBB and FSLIC, which demies anything other than limited, APA review in the courts.

19. See FSLIC v. Bonfanti, 826 F.2d 1391 (5th Cir. 1987), petition for cert. fled, 56 U.S.L.W. 3165 (U.S. Aug. 5, 1987) (No. 87-255); Morrison-Knudsen Co. v. CHG Int'l, Inc., 811 F.2d 1209 (9th Cir. 1987), petition for cert. filed sub nom. FSLIC v. Stevenson Assocs., 56 U.S.L.W. 3249 (U.S. Sept. 17, 1987) (No. 87-451); Murdock-SC Assocs. v. Beverly Hills Fed. Sav. \& Loan Ass'n, 624 F. Supp. 948 (C.D. Cal. 1985), aff'd in pait and rev'd in part, 815 F.2d 82 (9th Cir. 1987), petition for cert. filed sub nom. FSLIC v. Murdock-SC Assocs., 56 U.S.L.W. 3249 (U.S. Sept. 17, 1987) (No. 87 452). The claims in the Morrison-Knudsen case have now been settled. See Brief for the Respondent at 37 n.27, Coit Independence (No. 87-996).

These petitions raise only the question "[w]hether claims against the assets of an insolvent, federally insured savings and loan association must be presented in the first instance in federal receivership proceedings in accordance with the Federal Home Loan Bank Board's regulations for the administrative resolution of such clains." Petition for a Writ of Certiorari to the Umited States Court of Appeals for the Ninth Circuit at I, Murdock-SC Assocs. (No. 87-452).

20. See infra text accompanying notes 510-657.

21. See infra text accounpanying notes 545-600.

22. See infra text accompanying notes 91-92.

23. See infra text accompanying notes $325-429$. 
cating creditor claims in thrift receiverships is likely to remain important for as long as the crisis in the thrift industry persists and the present system of thrift regulation survives. ${ }^{24}$

This article seeks to provide some general answers to this basic question by drawing upon general constitutional and administrative law principles. Part I describes the background to the Hudspeth controversy by tracing the emergence and evolution of federal thrift regulation, the changing market environment, the attempts by the FHLBB to adapt to the escalation in thrift failures while coping with the rapid depletion of the federal deposit insurance fund, and the recent conflict in the courts concerning the validity of the FSLIC's assertions of adjudicatory jurisdiction. Part II describes the general receivership process and, nore particularly, the Hudspeth process as it has now been developed by the Bank Board. Part III turns to examine the constraints by which the Hudspeth procedures must be judged. This involves an investigation of the statutory authority supporting the adjudicatory scheme, the applicability of the APA, and the constitutional principles that should inforn the drafters of the scheme. Part IV evaluates the existing Hudspeth procedures according to the criteria identified in Part III, and this in turn leads to the recommendations, in the Conclusion, for clarifying the FHLBB's mandate and for improving its adjudicatory structure and claims resolution procedures.

24. It is, of course, conceivable that the industry might stabilize and that thrift fallures might decline. If this were to happen, the FHLBB might find it more practical to rely on judicial resolution of disputed creditor clains in the few receiverships that remained.

It should also be einphasized that the entire problem might be the product of the present regulatory system. For example, it has been argued that the system of federal deposit insurance, the price of which is not risk-related, has become a major contributor to thrift (and coininercial bank) failure because, in the competitive world of modern banking, it removes market disciplimes. In other words, it ehminates the incentive for depositor scrutiny that would restrain industry entrepreneurs from engaging in bad-risk activities, and it transfers the costs of risk-taking from the entrepreneurs to the insurance funds and, ultimately, the general public. See, e.g., E. KANE, THE GATHERING CRISIS IN FEDERAL Deposit INSURANCE 7-15 (1985); Barth, Brumbaugh, Sauerhaft \& Wang, Insolvency and Risk-Taking in the Thrift Industry: Implications for the Future, CoNTEMP. PoL'Y Iss., Fall 1985, at 1; Fischel, Rosenfield \& Stillinan, The Regulation of Banks and Bank Holding Companies, 73 VA. L. REv. 301, 312-18 (1987); Garten, Banking on the Market: Relying on Depositors to Control Bank Risks, 4 YALE J. ON REG. 129 (1986) (concluding that depositors generally are not able to control the level of their bank's risk-taking); Garten, Still Banking on the Market: A Comment on the Failure of Market Discipline, 5 YALE J. ON REg. 241 (1988) (same); Isaac, The Role of Deposit Insurance in the Emerging Financial Services Industry, 1 YALE J. ON REg. 195, 204 n.30 (1984); Macey \& Garrett, Market Discipline by Depositors: A Summary of the Theoretical and Empirical Arguments, 5 YALE J. ON REg. 215 (1988); O'Driscoll, Deposit Insurance in Theory and Practice, in THE FINANCial Services Revolution 165 (C. England \& T. Huertas eds. 1988); Scott \& Mayer, Risk and Regulation in Banking: Some Proposals for Federal Deposit Insurance Reform, 23 STAN. L. REV. 857 (1971). This article assumes no fundamental reforms to the present system. 


\section{EMERGENCE OF THE HUDSPETH DOCTRINE}

The present system of federal thrift regulation is the product of hastily enacted New Deal legislation that has been modified in a reactive, piecemeal fashion during the last half century. The model created by the Home Owners' Loan Act and the National Housing Act did not fully address the problem of hquidating thrifts in receivership; instead the legislators, to the extent that they thought about the problem at all, seemed concerned with the receiver's power to dispose of thrift assets rather than the method by which the validity of creditor claims should be handled. Claims determination was not directly addressed at all. ${ }^{25}$

To gain a full perspective, it is helpful to place the thrift industry within the broader context of the financial services industry and to describe the manner in which federal thrift regulation has evolved. We then need to examine the ways in which the thrift industry has developed since the inception of federal regulation. It is these developments that have created a need for an administrative claims settlement procedure.

\section{A. Thrifts and the Banking Industry.}

Liquidation procedures are not uniform throughout the banking industry, and we should take some account of the special position that thrifts occupy within banking. Thrifts are one of the three principal kinds of depository institutions, all of which are still governed by structures devised during the New Deal. ${ }^{26}$ The other coinponents are commercial banks and credit unions. ${ }^{27}$ Together, thrifts-savings and loan associations and savings banks-account for approximately $20 \%$ of the private assets held by all financial internediaries, ${ }^{28}$ and for a httle more than $35 \%$ of those held by depository institutions. ${ }^{29}$

25. See infra text accompanying notes 363-87.

26. The relevant legislation for present purposes is the Home Owners' Loan Act of 1933, ch. 64, 48 Stat. 128 (codified as amended at 12 U.S.C. $\$ \$ 1461-1470$ (1982)), the National Housing Act of 1934, ch. 847, 48 Stat. 1246 (codified as amended at 12 U.S.C. $\$ \S 1701-1750 \mathrm{~g}(1982)$ ) (governing the FHLBB and the FSLIC), the Banking Act of 1933, ch. 89, 48 Stat. 162 (codified as amended at 12 U.S.C. $\$ \S 1811-1832$ (1982)) (governing the Federal Deposit Insurance Corporation), the Banking Act of 1935, ch. 614, 49 Stat. 684 (codified as amended at 12 U.S.C. $\$ \$ 1811-1832$ (1982)) (same), and the Federal Credit Union Act of 1934, ch. 750, 48 Stat. 1216 (codified as amended at 12 U.S.C. $\S \S 1751-1795$ (1982)) (governing the National Credit Union Administration).

27. See generally 1 M. Malloy, The Corporate LaW of Banks $\S 1.2$, at 4-21 (1988).

28. See 2 id. app. at 923 chart 1.1. "Financial intermediaries" include insurance companies, real estatc investment trusts, mutual, state and local government retirement funds, etc., in addition to the three sets of depository institutions. Id.

29. See id. at 924 chart 1.2. The actual breakdown among depository institutions (as of December 31, 1983 and excluding international liabilities) was: savings and loan associations-28.7\%; mutual savings banks-6.75\%; commercial banks-61.0\%; and credit unions-3.55\%. Id. 
Thrifts, like commercial banks and credit unions, can be chartered as state or federal institutions. Even if chartered by a state, a thrift can be federally insured. ${ }^{30}$ Various components of the industry are regulated by different authorities. Federally chartered and federally insured, statechartered savings and loan associations are subject to the regulatory jurisdiction of the FHLBB and the FSLIC. Federally chartered savings banks are subject to the supervision of the FHLBB and the Federal Deposit Insurance Corporation (FDIC). Commercial banks are subject to the separate regulatory jurisdiction of the Federal Reserve Board (the "Fed"), the Coinptroller of the Currency (the "Comptroller"), and the FDIC. Federal credit unions are regulated by the National Credit Union Administration Board (NCUAB). ${ }^{31}$

Although originally formed to serve different functions, ${ }^{32}$ savings and loan associations and savings banks have coine increasingly to resenible commercial banks in their services, investunent patterns, and in the conduct of their business activities. ${ }^{33}$ Nevertheless, despite calls for the establishment of a unitary system of regulatory inachinery, ${ }^{34}$ they continue to be regulated by separate agencies and according to separate regulatory principles and procedures. This structure lias facilitated the development of thrift liquidation procedures that differ froin those employed by the FDIC when the latter liquidates banks. For exainple, except when appointed by the FHLBB as receiver of a savings bank, ${ }^{35}$ the FDIC has not attenipted to adjudicate the validity of creditor claims; instead, it rehes upon judicial determination in the courts. When acting as receiver of state-chartered banks, the FDIC is also subject to the jurisdiction of the relevant local state law in its conduct of each receivership. ${ }^{36}$

Having once been fairly narrowly confined, the business transactions in which the thrift industry has niore recently becoine involved have exposed thrifts to a broader range of creditor claims than was the case before 1980 . The size and coniplexity of claims have greatly increased,

30. The overwhelming majority of thrifts are federally insured, with only Massachussettschartered thrifts retaining a significant level of independence from federal regulation. See W. LOVETT, BANKING AND FINANCIAL INSTITUTIONS LAW 237-38, 251 (2d ed. 1988) (Massachussetts state insurance system is only significant remaining state insurance system for savings banks; by 1981, savings and loan associations insured by FSLIC represented $98 \%$ of all savings and loan assets).

31. On the structure, jurisdiction and powers of these agencies, see generally 1 M. MALLoY, supra note $27, \S 1.3$, at 21-72.

32. See infra note 52 and accompanying text.

33. See infra notes 53-68 and accompanying text.

34. See generally, e.g., 1 M. MALLoY, supra note $27, \S 1.4$, at 72-79.

35. See infra text accompanying notes 167-68.

36. See infra text accompanying notes 448-52. 
simultaneously magnifying the potential for disputes concerning their validity. These developments have rendered inadequate the traditional hiquidation processes employed by the FSLIC. They have created financial pressures that have induced the FHLBB and the FSLIC, in an attempt to contain the costs of liquidation, to devise new strategies for handling failed thrifts and for processing the claims of creditors administratively. At the same time, the complexity of many creditors' claims seems to have spurred attempts by creditors to hitigate their claims in the courts. ${ }^{37}$

With the convergence of thrift and commercial bank business, and the kinds of claims in receivership that this business tends to generate, the differences between the in-house, administrative claims determination procedures employed by the FHLBB and the FSLIC, on the one hand, and the external, judicial procedures relied upon by the FDIC, on the other, have begun to appear anomalous. It is not surprising, therefore, that those opposing the Hudspeth doctrine have argued that if the FDIC can rely on judicial settlement of creditors' claims, so too should the FSLIC. ${ }^{38}$

Yet one should not overlook the historical differences between commercial bank and thrift regulation, or the differences that still remain. The notion of a separately regulated thrift mdustry is premised upon the long-standing American concern for the protection and encouragement of private home ownership. It has been thought important that funds should always be channeled in the direction of private home purchasers, and the concept of jomt commercial bank/thrift regulation carries with it the danger that the private home buyer would be unable to compete for credit in the commercial marketplace. ${ }^{39}$ This concern has tended to promote a paternalistic outlook on the part of the thrift regulators, one that perhaps contributes to the desire to maintain an internal, self-sufficient and inexpensive liquidation process.

\section{B. Development and Structure of the Regulatory Framework.}

Before 1932 the federal governınent had no involvement in the thrift industry. State chartering and regulation of thrifts had existed, however, in a number of states since the early nineteenth century. ${ }^{40}$ Thrifts, bear-

37. For an indication of the scale of recent litigation, see infra notes $228-43$.

38. See infra text accompanying notes $430-46$.

39. See, e.g., Gray, The Role of Regulation in the Thrift Industry, 6 ANN. REv. BANKING L. 235, 236-37 (1987); Wallace, Home Ownership Drives the Thrift System, OuTLook, Sept.-Oct. 1986, at 9.

40. See generally W. LOVETT, supra note 30, at 232-35; E. SYMONS \& J. WHITE, BANKING LAw 51-52, 54-56 (2d ed. 1984); UNITEd STATES BLDG. \& LOAN LEAGUE, History Of BuildiNG AND LOAN IN THE UNITED STATES 123-32 (H. Bodfish ed. 1931) [hereinafter HistoRY of BuILDING AND LOAN]; Barth \& Regalia, The Evolving Role of Regulation in the Savings and Loan Indus- 
ing various titles such as "building associations," "savings and loan associations," and "savings banks," were chartered under the laws of the various states and were usually confined to narrowly localized operations. ${ }^{41}$ They were also subjected to increasingly intensive regulation and supervision, especially during the latter quarter of the nineteenth century. ${ }^{42}$

Federal regulation of the thrift industry came in the wake of major legislation governing commercial banks, ${ }^{43}$ and commenced with the creation of the Hoine Loan Bank System in 1932.44 More important was the enactment of the Home Owners' Loan Act of 1933,45 which empowered the recently created $\mathrm{FHLBB}^{46}$ to charter federal savings and loan associations and subject them to the FHLBB's regulation. A year later Congress established the FSLIC to provide federal deposit insurance for, exercise supervision over, and act as conservator or receiver in respect of, federal thrifts. At their option or that of their chartering state, statechartered building associations, savings and loan associations, hoinestead associations and cooperative banks could also apply for FSLIC insurance. The insurance fund was to be self-financing and replemished from premiums levied on the deposits of insured thrifts. The FSLIC was to act under the direction of the FHLBB. ${ }^{47}$

During the ensuing four decades the powers and jurisdiction of the FHLBB and FSLIC were extended im various directions (often together with thiose of the FDIC in respect of commercial banks). The FHLBB, for example, was granted powers to issue cease and desist orders, appoint the FSLIC as receiver for state-cliartered thrifts, charter savings banks,

try, in The Financial Services Revolution, supra note 24, at 113, 115-24; Lockwood, Thrift Industry Passes Its 170th Anniversary, OutLooK, Sept.-Oct. 1986, at 20. For a fuller discussion of the directly relevant legislative history, see infra notes 355-419 and accompanying text.

41. National institutions, which operated through branch offices and the mail, were driven out of business by opposition, largely from local thrifts and their lobby, the U.S. Savings and Loan League, during the economic depression of the 1890s. See W. LoveTr, supra note 30, at 246-47; HistORY OF BUILDING AND LOAN, supra note 40, at 105-15; Barth \& Regalia, supra note 40, at 120.

42. See History OF BUILDING AND LOAN, supra note 40, at 123-29; W. LOVETT, supre note 30, at 247.

43. Banking Act of 1933 , ch. 89,48 Stat. 162 (codified as amended at 12 U.S.C. $\S \S 1811-1832$ (1982)). This legislation created the FDIC and, adding § 12(B) to the Federal Reserve Act, ch. 6, 38 Stat. 251 (1913), established a system of federal deposit insurance for banks. Seetion 12(B) was later desiguated as a separate act, known as the Federal Deposit Insurance Act. See Act of September 21, 1950, ch. 967, § 1, 64 Stat. 873 (codified at 12 U.S.C. $\$ 264$ (1982)).

44. Federal Home Loan Bank Act of 1932, ch. 522, $\$ 17,47$ Stat. 725, 736-37 (codified as amended at 12 U.S.C. $\$ 1437$ (1982)) (creating the Federal Home Loan Bank Board and twelve home loan bank districts); see also infra text accompanying notes 357-60.

45. Ch. 64,48 Stat. 128 (codified as amended at 12 U.S.C. $\$ 1464$ (1982)).

46. See supra note 44 and accompanying text.

47. National Housing Act of $1934 \S 402,12$ U.S.C. $\S 1725$ (1982) (current section includes minor amendments to original section 402). 
and convert state thrifts to federal charter. The FSLIC was given powers to terminate federal insurance, extend financial assistance to troubled thrifts, and borrow money to replenish its insurance fund. ${ }^{48}$

The picture that enterges is that of the FHLBB exercising chartering and directory powers over two imsuring agencies, the FSLIC and the FDIC (in the limited case of federal savings banks), each of which in turn exercises extensive regulatory powers over the thrifts insured by them and each of which is appointed in a separate institutional capacity as the receiver of any such thrifts when they fail.

Concern for protecting small investors has not been the only force driving the growth of federal thrift regulation. Thrifts are an important element in the inaintenance of the public supply of money, 49 and the nraintenance of public confidence in the thrift system is thought to be an essential national concern. ${ }^{50}$ It is not surprising, therefore, that "the financial industry, particularly the depository institutions segment, is one of the most heavily regulated industries in America." 51

\section{Transformation of the Thrift Industry.}

The original function of savings and loan associations was the narrow one of receiving deposits from would-be home owners and providing loans to depositors for the purpose of building or acquiring real property, particularly housing. Only at a later stage did savings and loan associations begin lending to borrowers who were not also their depositors. Savings banks, on the other hand, were philanthropic, being origimally designed to provide financial services for the small saver. The ouly significant creditors of both savings and loan associations and savings banks, traditionally, were their depositors. ${ }^{52}$

In recent years, however, savings and loan associations and savings banks have not only tended to converge, both structurally and functionally, ${ }^{53}$ but they have become exposed to a novel range of concerns. From

48. See infra text accompanying notes $388-419$ (describing some of the relevant legislation).

49. See M. Friedman \& A. Schwartz, A Monetary History of the UNITEd States $1867-1960$, at 662-72 (1963).

50. See, e.g., Barth, Brumbaugh, Sauerhaft \& Wang, supra note 24, at 2-3; Note, The "Brokered Deposit" Regulation: A Response to the FDIC's and FHLBB's Efforts to Limit Deposit Insurance, 33 UCLA L. REV. 594, 603-04 (1985).

51. Barth \& Regalia, supra note 40, at 114; cf. Fahey v. Mallonnee, 332 U.S. 245, 250 (1947) (Jackson, J.) ("Banking is one of the longest regulated and most closely supervised of all public callings." (referring to the regulatory powers of the FHLBB)).

52. See generally Federal Home LoAN BaNK System, A Guide to the Federal Home LOAN BANK SYSTEM 5-6 (5th ed. 1987) [heremafter FHLB GuIDE]; HISTORY OF BuILDING AND LOAN, supra note 40, at 11-18; Barth \& Regalia, supra note 40, at 115-16; Gray, supra note 39, at 238-40; Lockwood, supra note 40, at 20.

53. See, e.g., E. Symons \& J. Whrre, supra note 40, at 57-58. 
the early 1960s, a series of developments completely altered the economic environment within which thrifts function. The most important of these developments were: (i) increasing competition between thrifts and banks; (ii) the deregulation and volatility of interest rates; and (iii) the decline in inflation and the collapse of the oil boom..$^{54}$

In the 1960s, thrifts found themselves under imcreasing competition from commercial banks for small savers. The Fed permitted banks to pay higher interest rates on certain popular kinds of deposits, and thrifts suffered severe disintermediation (loss of funds). The Act of September $21,1966,55$ which permitted thrifts to offer shightly higher rates on savings deposits than commercial banks, restored some protection for thrifts. ${ }^{56}$ But, with the passage of the Housing and Urban Development Act of 1968,57 which gave thrifts broader investment powers, thrifts entered into direct competition with banks in the provision of many financial services.

By the late 1970s both banks and thrifts were facing external competition from money market funds. This development induced Congress to enact the Depository Institutions Deregulation and Monetary Control Act of 1980,58 the purpose of which was to phase out ceilings on maximum interest rates. But one effect was to plunge thrifts into a "trial by interest rates"59 as they competed for deposits while finding themselves locked into long-term mortgages that bore much lower rates of return. ${ }^{60}$

Attempting to resolve this dilemma, Congress enacted the Garn-St Germain Depository Institutions Act of 1982.61 The Act allowed thrifts to diversify and expand their portfohos into other investments, subject to a limitation that these new assets not exceed $10 \%$ of their total assets. Some states, including California and Texas, went further and lifted all asset limitations from their state-chartered thrifts. ${ }^{62}$ Deregulation paved the way for thrifts to enter whole new areas of business activity and,

54. See generally F. Balderston, Thrifts in CRISIs 4-9 (1985); A. CARron, The Plight of THE THRIFT INSTITUTIONS 11-21 (1982); FHLB GUIDE, supra note 52, at 13-23; W. LOVETT, supra note 30, at 227-32; Kriz, The Sick Get Sicker, 1987 NAT'L J. 874, 875-76; Pfeiler, FSLIC Adjudication of Claims Against Receiverships: Has the Search for Efficiency Lost Sight of Due Process?, 53 LEGAL Bull. 433, 433 n.1 (1987); Note, supra note 50, at 608-12.

55. Pub. L. No. 89-597, 80 Stat. 823 (codified in scattered sections of 12 U.S.C.) (amending the Federal Reserve Act, Federal Deposit Insurance Act, and Federal Home Loan Bank Act).

56. See, e.g., Lockwood, supra note 40, at 23.

57. Pub. L. No. 90-448, 82 Stat. 476 (codified in scattered sections of 12 U.S.C. ch. 13).

58. Pub. L. No. 96-221, 94 Stat. 132 (codified at 12 U.S.C. $\S \S 3501-3524$ (1982)).

59. FHLB GuIDE, supra note 52, at 18.

60. See F. BALderston, supra note 54, at 5-6; A. CARRON, supra note 54, at 12-13.

61. Pub. L. No. 97-320, 96 Stat. 1469 (codified in scattered sections of 12 U.S.C.).

62. For a recent survey of the extensive difficulties currently confronting state-chartered and state-regulated thrifts, see Bancroft, Banking on Deregulation Can Be Hazardous to Your State's Financial Institutions, GOVERNING, Jan. 1988, at 44. 
through high-risk business ventures accompanied by the ability to offer automatic federal insurance to potential depositors, ${ }^{63}$ to grow at "astronomical rates" until the FHLBB placed caps on growth rates in 1983.64

The next blow canie from the decline in the inflation rate and the sudden slump in oil-driven economic prosperity, particularly in the Southwest. Anticipating exponential increases in the value of real estate, thrift inanagers had often grossly overextended themselves. ${ }^{65}$ When the oil boom ended, the poor asset quality of their investinents threw well over 100 thrifts into difficulties with the FHLBB's minimum asset requirements, and dozens immediately becanie insolvent. ${ }^{66}$ Hence the primary cause of thrift failure had shifted by the mid-1980s from the interest rate squeeze of the late 70 s and early 80 s to imprudent investment strategies, ${ }^{67}$ and a major contribution to the difficulties in which thrifts have found themselves has been the relative inexperience of thrift managers in the new areas of enterprise into which deregulation has so rapidly thrust them.68

Finally, the Tax Reform Act of 1986,69 which adversely affected the value of real estate development, has probably also had a significant intpact on the asset portfolios of the inore fragile thrifts. ${ }^{70}$

\section{Escalation of Thrift Failures and Depletion of the FSLIC's Insurance Fund.}

To cope with the ailing state of the industry, Congress has given the FHLBB broader powers for dealing with failed or failing thrifts, ${ }^{71}$ and

63. On the distortions produced by the deposit insurance "subsidy," see E. KANE, supra note 24, ch. 5 .

64. See Kriz, supra note 54 , at $875-76$.

65. See id. at 877; Note, supra note 50, at 611-12.

66. See Kriz, supra note 54 , at 877.

67. "In [1982], inost of the thrift problems stemmed from interest rate risk (spread problems), whereas in 1986 the cases were almost exclusively related to credit risk (bad-asset cases)." 1986 FHLBB ANN. REP. 26-27 (1987).

68. Speaking on the diversification permitted thrifts as a result of the Gam-St Germain Depositary Institutions Act, the former general counsel of the FHLBB, Harry Quillian, has remarked, " 'You had 4,500 institutions at that tine that were suddenly thrown into, or thought they must jump into, business activities that they were not used to and not really prepared for, to make more money to recoup their positions,...." Kriz, supra note 54, at 875.

Managerial incompetence, however, is not confined to ailing thrifts. According to the Comptroller of the Currency, citing a study of the causes of bank failures from 1979 to 1987, "banks continue to fail the old-fashioned way: through managerial incompetence ..." Bank-Failure Causes Cited, N.Y. Times, Jan. 21, 1988, at D9, col. 5 (city ed.).

69. Pub. L. No. 99-514, 100 Stat. 2085 (codified in scattered sections of 26 U.S.C.A.).

70. For an analysis of the Act's likely impact on real estate and mortgages, see Johnson, Financial Impact of the 1986 Act on Real Estate Investments-A View from the Spreadsheets, 36 TAX NOTES 309 (1987).

71. See infra text accompanying notes 407-19. 
the FHLBB has taken various forms of action itself. For example, in 1976 it promulgated a regulation permitting federal thrifts to incorporate "due-on-sale" clauses in their loan instruments as a device for escaping their commitments on sales of the mortgaged property. ${ }^{72}$ In 1985 the FHLBB issued a rule requiring supervisory approval of direct investment by FSLIC-insured thrifts in excess of certain specified thresholds. ${ }^{73} \mathrm{~A}$ "management consignment program," designed to enable the FSLIC to take control and improve the health of troubled thrifts before they become too great a burden on the FSLIC, has been instituted, ${ }^{74}$ and, in an effort to improve the quantity and quality of its regulatory supervision force, the Board has transferred its examination functions and examiners to the twelve District Banks. ${ }^{75}$

These and other measures, ${ }^{76}$ while helping to contain the problem, have not proven enough to stem the tide. The number of "bram dead" and "terminally ill" thrifts"7 that are so irretrievable as to compel their liquidation has grown rapidly in recent years. Whereas during the entire period froin 1934 to 1980 the FHLBB put only 13 thrifts into hiquidation, in 1987 alone it put 25 into receivership and liquidated 17,78 and the

72. 12 C.F.R. § 545.34(a) (1988); see Fidelity Fed. Sav. \& Loan Ass'n v. De la Cuesta, 458 U.S. 141 (1982) (uplolding the validity of the regulation over state law prohibiting sucl clauses). Express preemption, under certain circumstances, of due-on-sale provisions was incorporated in the Thrift Institutions Restructuring Act, Pub. L. No. 97-320, § 341, 96 Stat. 1496, 1505 (1982) (codified at 12 U.S.C. $\S 1701 j-3$ (1982)).

73. See 1985 FHLBB ANN. REP. 17 (1986). This measure was bolstered by the Thrift Industry Recovery Act, Pub. L. No. 100-86, § 406, 101 Stat. 604, 614 (1987) (codified at 12 U.S.C.A. $\$ 1464$ (West Supp. 1988)), which empowers the FHLBB to establish minimum capital requirennents and to treat the failure to observe these requireinents as an unsound or unsafe practice.

74. See 1986 FHLBB ANN. Rep. 17, 28 (1987). But see infra note 152.

75. See 1985 FHLBB ANN. ReP. 21 (1986); Gray, supra note 39, at 242-44.

76. See, e.g., Pfeiler, supra note 54, at 434 n.4 (restructuring and increasing staff size).

77. See Kriz, supra note 54 , at 875 .

78. The number of receiverships during the life of the FSLIC is as follows:

$\begin{array}{ll}1934-39 & =0 \\ 1940-41 & =7 \\ 1942-65 & =0 \\ 1966-71 & =6 \\ 1972-80 & =0 \\ 1981 & =1 \\ 1982 & =6 \\ 1983 & =9 \\ 1984 & =11 \\ 1985 & =21 \\ 1986 & =25 \\ 1987 & \text { (to July 1) }\end{array}$

See 1986 FHLBB ANN. REP. 31-35 (1987); FHLB GUIDE, supra note 52, at 18, 21-22; Grant, The FSLIC: Protection Through Professionalism, FHLBB J., Feb. 1981, at 9; telephone interview with Judith L. Friedman, Associate General Counsel, FHLBB (Aug. 29, 1988). In addition, 24 thrifts were placed into the management consignment plan in 1987 and one more added as of July $1,1988$. Id. 
Board's present chairman recently estimated that the agency will close one thrift a week in 1988.79 In Texas alone the FHLBB plans to close or merge 104 thrifts during 1988.80

The potential magnitude of receivership claims is evident from the fact that approximately 340 , and perhaps as many as 510,81 thrifts-representing $10 \%$ of the industry-are currently estimated to be insolvent. ${ }^{82}$ The pressure of depositor payouts drove the federal insurance fund itself into a $\$ 6.3$ billion deficit by the beginning of $1987 .{ }^{83}$ A congressional/ executive compromise culminated in the Competitive Equality Banking Act of 1987,84 title III of which authorized the FSLIC to recapitalize its insurance fund (thereby enabling a fresh batch of moribund thrifts to be put into receivership).

Yet even this ineasure has proved inadequate. Healthy thrifts have protested their obhigation to support, through the emergency special insurance assessments levied on their deposits, the mismanagement of their ailing counterparts. Those ehgible to do so have embarked upon a "silent run," electing to leave the FSLIC insurance system and seek FDIC insurance. ${ }^{85}$ Some thrift industry experts beheve a second bailout, possibly involving an appropriation of taxpayer funds, will soon be required. ${ }^{86}$ And the General Accounting Office recently reported to the Senate

79. See Day, More Hard Times for $S \&$ Ls, Wash. Post, Dec. 21, 1987, at 22, cols. 1, 4 (weekly ed.). By late July, 44 thrifts had actually failed in 1988, as compared with 48 for the whole of 1987 . See Hilder, Shaky Coverage, Wall St. J., July 27, 1988, at 1, col. 6, 16, col. 2.

80. See Hayes, Bank Board Plan Near on Texas Savings Units, N.Y. Times, Jan. 16, 1988, at 21, col. 5 (national ed.) (Texas's "troubles represent about half of our problems nationwide." (quoting M. Danny Wall, Chairman, FHLBB)). In the space of six weeks the FHLBB recently had to double the estimate of its costs in closing or merging insolvent Texas thrifts, from $\$ 7$ billion to $\$ 15.2$ billion. See Nash, Bank Board Doubles Texas Cost Estimate, N.Y. Times, July 8, 1988, at 23, col. 4 (national ed.).

81. The amount varies according to whether generally accepted accounting principles, which the thrift industry will have to use beginning in 1989, or regulatory accounting primciples, which produce lower figures, are used. See Nash, Record Loss for Savings Industry, N.Y. Times, March 25, 1988, at D1, cols. 3, 5 (city ed.).

82. See Day, supra note 79, at 22, col. 3; Hayes, supra note 80; Nash, supra note 81, at D1, cols. 3-5. In a report to the Senate Banking Committce, the General Accounting Office recently noted that the FHLBB has identified more than 200 hopelessly insolvent thrifts and another 300 that are insolvent under generally aecepted accounting primciples. See Nash, $A$ Gloomy Report on F.S.L.I.C., N.Y. Times, May 20, 1988, at 27, col. 3, 28, col. 3 (national ed.).

83. See 1986 FHLBB ANN. ReP. 25 (1987).

84. Pub. L. No. 100-86, 101 Stat. 552 (to be codified in scattered sections of 12 U.S.C.A.).

85. See Nash, FSLIC's Second Bailout Is Studied, N.Y. Times, Mar. 7, 1988, at 23, col. 6, 26, cols. 3-4 (national ed.).

86. See id. at 23, col. 6. This situation has led one of the nation's inajor thrift industry lobbies, the National Council of Savings Institutions, among others, to propose a contingency plan involving the merger of the FSLIC and the FDIC and their msurance funds. See id. at 26, col. 1; Statement by J. Morgan, Chairman of the National Council of Savings Institutions, Washington, D.C. (Mar. 2, 1988). 
Banking Committee that at the end of 1987 the federal insurance fund deficit had grown to $\$ 13.7$ billion-more than twice the level at which it had stood only one year before. ${ }^{87}$

Pressures on the insurance fund have been accompanied by an escalation in the costs of administering the increasing volume of receiverships. For exainple, in 1986 alone annual insurance settleinent and administrative costs increased from $\$ 31.2$ million to nearly $\$ 57$ million. ${ }^{88}$

\section{E. Reaction and Adaptation at the FHLBB.}

The financial difficulties of the Insurance Fund, and the rapid increase in the cost of assisting and liquidating failed thrifts, forced the FHLBB and FSLIC to investigate ways of reducing expenses and expediting its procedures. For those thrifts that are thought to be salvageable, the FHLBB and the FSLIC have developed various techniques designed to avoid either having to place a thrift in receivership ${ }^{89}$ or, if this is unavoidable, having to liquidate it once it has been placed in receivership. ${ }^{90}$ In these ways the FSLIC has been able to reduce significantly the actual and potential payouts from the insurance fund that it might otherwise have to inake.

The agencies have also tried to contain the costs of receiverships by developing exclusive, internal clanns adjudication procedures. The importance to the agencies of these procedures is expressed in a report, referring to the FSLIC's victory in the Hudspeth decision, ${ }^{91}$ by the Litigation and Special Projects Division of the FHLBB's Office of General Council:

The Division won a significant decision establishing the exclusivity of the FSLIC's procedures for administrative adjudication of creditors' claims against the assets of institutions in receivership. The decision confirmed that the FSLIC, as receiver, must inake an initial determina-

87. See Nash, supra note 82 , at 27, col. 3. A short while earlier the FHLBB itself announced that at the end of 1987 the federal insurance fund deficit had grown to $\$ 11.6$ billion. See Day, Deficit Growing at FSLIC, Wash. Post, Apr. 18, 1988, at A1, A8; Nash, Fund to Insure Savings Industry in Critical State, N.Y. Times, Apr. 19, 1988, at 1, col. 1 (national ed.). More recently, the chairman of the FHLBB and an undersecretary of the Treasury estimated that an amount of $\$ 30$ billion would be required to bail out the nation's thrift industry. See Nash, Treasury Says Savings Aid Shouldn't Tax the Taxpayer, N.Y. Times, Aug. 3, 1988, at 25, col. 4 (national ed.) (reporting on hearings conducted by the Senate Banking Committec). The following day the chairman of the FDIC disagrced, stating that in his view a sum of $\$ 50$ billion was required. See Hershey, FSLIC's Need Put at $\$ 50$ Billion, N.Y. Times, Aug. 4, 1988, at 25, col. 6 (national ed.).

88. See 1986 FHLBB ANN. REP. 25 (1987). According to one report, legal fees charged to the FSLIC by outside counsel rose to $\$ 87$ million for 1987 , compared with $\$ 37$ million for 1986 . See Brogan, Bank Failures Spell Success for Firms, Legal Tines, June 6, 1988, at 4, col. 1.

89. See infra text accompanying notes 149-52.

90. See infra text accoinpanying notes 189-95.

91. See infra text accompanying notes 98-117. 
tion concerning the validity and priority of a creditor's claim, with further administrative review by the Board, before the courts may intervene. This decision will pronote the efficiency of the hquidation process and result in enornous savings in legal fees. ${ }^{92}$

The administrative procedures existing when Hudspeth was decided were virtually nonexistent, however, so the Adjudication Division of the Office of General Counsel of the FHLBB has since been engaged in developing new procedures. This process remains incoinplete: a series of proposed and interim rules amending existing procedures have been published since late 1985, but final rules have still not been pubhished by the Board.93 Meanwhile, however, the agencies have found themselves einbroiled in hitigation challenging both the statutory and the constitutional bases of their asserted adjudicative power. ${ }^{94}$ Hence the procedures that have so far been instituted remain not only fluid and experimental but also of uncertain legal status.

\section{F. Conflict in the Courts.}

To establish and enforce its asserted power as receiver to adjudicate creditors' claims, the FSLIC has adopted the practice of seeking to have claims suits that have been initiated in state courts removed to the federal courts, where the FSLIC then moves for them to be dismissed for want of subject matter jurisdiction. The FSLIC's argument is that, as receiver, it has been vested with the power to determine for itself the validity of creditor claims, ${ }^{95}$ and that the jurisdiction of the courts to make independent deteriminations has been precluded.96

This strategy has often proved successful. Having secured some acknowledgement of its position from the federal district court in Hawaï,97

92. 1985 FHLBB ANN. REP. 46 (1986). On the other hand, the motives underlying the agencies' propagation of the Hudspeth doctrine have been questioned by a former General Counsel of the FHLBB. See Leibold, The Hudspeth Doctrine: Its Conception, Birth and Possible Demise 1 (Oct. 67,1988 ) (unpublished paper to be delivered at ALI-ABA Course of Study: Failing Financial Institutions, Washington, D.C.) ("The Hudspeth doctrine was conceived because, I believe, legal counsel for the FSLIC, not as receiver but as insurer-creditor, altlough couusel were wearing botll hats, attempted to raise any possible legal argument to frustrate whiat they concluded to be 'black liat' creditors who had obtained verdicts or judgments in civil courts, nsually prior to the appointment of a receiver for the association.").

93. See infra text accoinpanying notes 201-05.

94. See infra notes $97-148$ and accompanying text.

95. The FSLIC relies on $\S 406$ (d) of the National Housing Act of 1934, 12 U.S.C. $\$ 1729$ (d) (Supp. IV 1986). See infra text aceompanying note 186 (quoting the subsection).

96. Here the FSLIC relies on $\S 5(\mathrm{~d})$ of the Home Owners' Loan Act of 1933, 12 U.S.C. $\S 1464(d)(6)(C)$ (1982). See infra text accompanying note 178 (quoting the subsection).

97. See First Sav. \& Loan Ass'n v. First Fed. Sav. \& Loan Ass'n, 531 F. Supp. 251, 255-56 (D. Haw. 1981); cf. First Sav. \& Loan Ass'n v. First Fed. Sav. \& Loan Ass'n, 547 F. Supp. 988, 994, 99697 (D. Haw. 1982). Contra W-V Enters. v. FSLIC, 234 Kan. 354, 372, 673 P.2d 1112, 1125 (1983) 
the FSLIC's interpretation of the legislation was firmly endorsed by the Fifth Circuit in North Mississippi Savings \& Loan Association v. Hud$s p e t h, 98$ which quickly became the leading case on the subject.

1. Hudspeth: The "Administrative Track." Hudspeth involved a dispute between a thrift (Old North) and its former president (Hudspeth). When in 1977 Mississippi law required all state-chartered thrifts to obtain FSLIC insurance, the FSLIC refused to approve insurance for Old North unless Hudspeth was replaced. He resigned and Old North began paying him a regular monthly amount, which Hudspeth claimed to be a deferred coinpensation agreement. This agreement was repudiated by Old North in 1982, when the thrift filed in Mississippi chancery court for a declaration that the agreement either did not exist or was terminable. Hudspeth filed a counterclaim for contractual damages and specific performance.

During these proceedings the State of Mississippi placed Old North in receivership and appointed the FSLIC as receiver. On the same day the FHLBB federalized the receivership and named the FSLIC as sole receiver. ${ }^{99}$ The FSLIC, following one of its usual practices in hiquidations, ${ }^{100}$ then formed a new thrift (New North) and transferred to New North all of Old North's assets and liabilities except its liabilities to stockholders and any obligation owed to Hudspeth. The FSLIC then terminated paynents to the former president.

After the FSLIC, as receiver for Old North, had unsuccessfully moved for dismissal of Hudspeth's counterclaim, Hudspeth filed an amended counterclaim joining New Nortl as a party, the latter being an alleged transferee in interest. The FSLIC and New North then removed the action to a federal court and inoved sucessfully to dismiss the counterclaim. Hudspeth's motion to remand to state court was denied. The

(FSLIC unsuccessfully argues for the dissolution of an attachment order on the grounds that the order "interfere[d] with its hquidation of [the defendant thrift]").

98. 756 F.2d 1096 (1985), cert. denied, 474 U.S. 1054 (1986). The scope of this decision is not clear. For example, the Fifth Circuit has declared Hudspeth inapplicable to the resolution of claims liabilities assumed by transferee thrifts in a purchase and assumption transaction. See Bean v. Independent Am. Sav. Ass'n, 838 F.2d 739, 742 (5th Cir. 1988). Hudspeth was also ignored in a case in which the FSLIC unsuccessfully asserted exclusive jurisdiction to determine whether certain deposits were insured. See Jugum v. FSLIC, 637 F. Supp. 1045, 1048 (W.D. Wash. 1986); cf. Herbert v. National Credit Union Admin. Bd., 663 F. Supp. 833, 839-44 (E.D. Mo. 1987) (doubting Hudspeth's applicability in the case of insured deposits). On the justiciability of insurance claims, see infra text aceoinpanying notes 468-72.

99. For the conditions under which this is permissible, see infra text accompanying notes 170 75.

100. See infra text accompanying note 193 . 
case then took a remarkable course: a panel of the Fifth Circuit ${ }^{101}$ first upheld Hudspeth's appeal in part, ${ }^{102}$ then a few weeks later dismissed it altogether. ${ }^{103}$

In its withdrawn opimion, the court had agreed that the presence of New North and the FSLIC rendered the action removable to the federal court, and the panel agreed that the district court had "properly dismissed all of Hudspeth's claims against New North and much of his action against Old North."104 The court accepted that Hudspeth's assertion that the FSLIC was not authorized to set aside his contract was, as a result of the operation of 12 U.S.C. sections $1464(d)(6)(C)$ and 1729(d), 105 "route[d] to the administrative process." 106 But the court concluded that Hudspeth's claim against Old North for payment of past services rendered was not barred and should be remanded to the state court. ${ }^{107}$ The panel agreed with Hudspeth that neither section 1464(d)(6)(C) nor section 1729(d) barred the judicial determination of the validity of Hudspeth's claim against Old North. Relying upon Supreine Court decisions, ${ }^{108}$ the court took the view that "the adjudication of clains against a debtor, as opposed to the allocation of assets to

101. Judge Higginbotham wrote the panel's opinious, with Judges Thornberry and Reavley concurring.

102. The court's initial opinion, dated April 5, 1985, was reported in West's advance sheets as North Miss. Sav. \& Loan Ass'u v. Hudspeth, 756 F.2d 1096 (5th Cir. 1985) [hereinafter Hudspeth, withdrawn]. The opinion is reprinted as Appendix A to Pfeiler, supra uote 54, app. at 471-75.

103. The second opinion is coutained in West's bound volune. See North Miss. Sav. \& Loan Ass'n v. Hudsspeth, 756 F.2d 1096 (5th Cir. 1985), cert. denied, 474 U.S. 1054 (1986) [hereinafter Hudspeth].

104. Hudspeth, withdrawn, supra note 102, 756 F.2d at 1098.

105. See supra text accompanying notes 95-96.

106. See Hudspeth, withdrawn, supra note 102, 756 F.2d at 1101.

107. See id. at 1098-99, 1103. The court had been briefed on the possible unconstitutionality of the FSLIC's claimed adjudicative powers and on the question whether the statutory authority to adjudicate existed; in its opinion, however, the court, chose to address only the issue of statutory adjudicative authority. The constitutional questions raised were whether the claimed adjudicative power violated article III of the U.S. Constitutiou, whether the administrative procedures available for deternining the clain were inadequate when neeasured against the requirements of procedural due process, and whether the FSLIC's conflict of interest in determining claims while beimg one of the creditors violated due process. Telephone interview with Wylene W. Dunbar, counsel for Hudspeth (Mar. 18, 1988).

108. Underwriters Nat'1 Assur. Co. v. North Carolina Life \& Aceideut \& Health Ins. Guar. Ass'n, 455 U.S. 691, 711 n. 19 (1982); Morris v. Jones, 329 U.S. 545 (1947); Riehle v. Margohes, 279 U.S. 218 (1929); cf. Tcherepnin v. Knight, 389 U.S. 332, 346 (1967) (deternimation of existence of a "seeurity" is distinct from question of the priority of claims in receivership, and is a justiciable issue); Chicago Titlc \& Trust Co. v. Fox Theatres Corp., 69 F.2d 60, 61 (2d Cir. 1934) (determination, or "liquidation," of creditor clain is a proceeding in personam against insolvent debtor, and does not directly deal with receivership assets or receivership itself); Tocci Corp. v. Yaukee Bank for Fin. \& Sav., FSB, No. Civ. A. 87-3121-K (D. Mass. 1988) (Westlaw, 1988 WL 70344) ("At common law, receivers have no power to adjudicate claims."). 
satisfy those claims, is not a receivership function."109

The FSLIC then petitioned for rehearing, arguing that the effect of the court's decision would be to place in further jeopardy the already precarious insurance fund. The FSLIC referred to the legislative history of the 1966 and 1968 amendments to the powers of the FHLBB and FSLIC in support of its arguinent that, as receiver, it possessed the exclusive power to adjudicate creditor claims. ${ }^{110}$ Hudspeth was not called upon to respond to the petition. ${ }^{111}$ The court decided to revise its decision, this time accepting the FSLIC's arguinents in their entirety, and the Supreme Court subsequently denied Hudspeth's petition for certiorari..12

In its revised opinion, the panel adopted the view that legislative history"13 indicated that "Congress wanted the FSLIC to be able to act quickly and decisively in reorganizing, operating, or dissolving a failed institution," 114 and that the legislation expressed "the overriding Congressional purpose of expediting and facilitating the FSLIC's task as receiver." 115 Hence, Judge Higginbotham opined, "resolution of even the facial inerits of claims outside of the statutory reorganization process would delay the receivership function of distribution of assets" 116 and, in violation of section 1464(d)(6)(C), would constitute a restramt of the receivership. He concluded:

In short, all of Hudspeth's claims are switched to the administrative track by section 1464(d)(6)(C). Hudspeth can challenge the FSLIC's actions before the FHLBB, and, if unsatisfied, can seek judicial review under the APA. ${ }^{117}$

The revised Hudspeth decision was a major victory for the FHLBB and the FSLIC. It was rapidly followed in a host of district court deci-

109. See Hudspeth, withdrawn, supra note 102, 756 F.2d at 1102. The court's conclusion is worth noting, since it rests upon a long-standing distinction between the recognition of pre-receivership claims and the exercise of general receivership powers. The court concluded:

When read in concert, 12 U.S.C. $\$ \S 1464(d)(6)(C), 1729$, and $1730(k)(1)$ construct an orderly scheme. In suits against a state savings institution in a federalized receivership, where the relief requested would interfere with or overturn the effect of any exercise of receivership power, the suit must be dismissed in favor of administrative proceedings before the FHLBB. If, however, an action is based on the pre-receivership conduct of the failed institution, the debt due nay be judicially established.

Id. at 1103. On the distinction, see infra text accompanying notes 347-53. On subsection $1730(k)(1)$, see infra text accoinpanying notes 449-52.

110. On this legislative history, see infra text accompanying notes $395-412$.

111. Telephone interview, supra note 107.

112. Hudspeth v. North Miss. Sav. \& Loan Ass'n, 474 U.S. 1054 (1986).

113. On the court's use of the legislative history, see infra notes 381-410.

114. Hudspeth, supra note 103,756 F.2d at 1101 .

115. Id. at 1102 .

116. Id.

117. Id. at 1103. 
sions, ${ }^{118}$ in those of a significant number of state courts, ${ }^{119}$ and has been reaffirmed in a series of subsequent Fifth Circuit decisions. ${ }^{120}$ It was also followed in a somewhat equivocal decision of the Seventh Circuit. ${ }^{121}$ In addition, a panel of the Nimth Circuit, dealing with the special case ${ }^{122}$ of a claim brought by an insolvent thrift against the FSLIC for having alleg-

118. See Blakely Airport Joint Venture II v. FSLIC, 678 F. Supp. 154 (N.D. Tex. 1988); Peoples' Sav. \& Loan Ass'n v. First Fed. Sav. \& Loan Ass'n, 677 F. Supp. 1104 (D. Kan. 1988); Vemon Sav. \& Loan Ass'n v. Homes Int'l Dev. Corp., 676 F. Supp. 247 (S.D. Fla. 1988); Resna Assocs. v. Financial Equity Mortgage Corp., 673 F. Supp. 1371 (D.N.J. 1987); FSLIC v. Florida 100 Dev. Group, 670 F. Supp. 1577 (S.D. Fla. 1987); York Bank \& Trust Co. v. FSLIC, 663 F. Supp. 1100 (M.D. Pa. 1987), vacated and remanded, 851 F.2d 637 (3d Cir. 1988); Acquisition Corp. of Am. v. Sunrise Sav. \& Loan Ass'n, 659 F. Supp. 138 (S.D. Fla. 1987); FSLIC v. Oldenburg, 658 F. Supp. 609 (D. Utah 1987); FSLIC v. Hall Whispertree Assocs., 653 F. Supp. 148 (N.D. Tex. 1986); Kohlbeck v. Kis, 651 F. Supp. 1233 (D. Mont. 1987); FSLIC v. Quality Inns, Inc, 650 F. Supp. 918 (D. Md. 1987); Baskes v. FSLIC, 649 F. Supp. 1358 (N.D. Ill. 1986); Baer v. Abel, 649 F. Supp. 25 (W.D. Wash. 1986); Baer v. Abel, 648 F. Supp. 69 (W.D. Wash. 1986); Colony First Fed. Sav. \& Loan Ass'n v. FSLIC, 643 F. Supp. 410 (C.D. Cal. 1986); FSLIC v. Sajovich, 642 F. Supp. 74 (C.D. Cal. 1986); Sunrise Sav. \& Loan Ass'n v. Lir Dev. Co., 641 F. Supp. 744 (S.D. Fla. 1986); First Am. Sav. Bank, F.S.B. v. Westside Fed. Sav. \& Loan Ass'n, 639 F. Supp. 93 (W.D. Wash. 1986); Rembold v. Gibraltar Sav. \& Loan Ass'n, 624 F. Supp. 1006 (W.D. Wash. 1985), rev'd sub nom. Morrison-Knudsen Co. v. CHG Int'l, Inc., 811 F.2d 1209 (9th Cir. 1987), petition for cert. filed sub nom. FSLIC v. Stevenson Assocs., 56 U.S.L.W. 3249 (U.S. Sept. 17, 1987) (No. 87-451); Murdock-SC Assocs. v. Beverly Hills Fed. Sav. \& Loan Ass'n, 624 F. Supp. 948 (C.D. Cal. 1985), aff'd in part and rev'd in part, 815 F.2d 82 (9th Cir. 1987), petition for cert. filed sub nom. FSLIC v. Murdock-SC Assocs., 56 U.S.L.W. 3249 (U.S. Sept. 17, 1987) (No. 87-452); Gibraltar Bldg. \& Loan Ass'n v. State Sav. \& Loan Ass'n, 607 F. Supp. 722 (N.D. Cal. 1985); cf. First Fin. Sav. \& Loan v. FSLIC, 651 F. Supp. 1289 (E.D. Ark. 1987) (Hudspeth decision recognized but FSLIC held estopped froln reconsidering merits of claims already determined in state court). Unreported decisions have becn omitted to save space.

119. See Modern Supply Co. v. FSLIC, 50 Wash. App. 194, 748 P.2d 251 (1987) (sphit decision); Keller v. Antioch Sav. \& Loan Ass'n, 143 Ill. App. 3d 278, 492 N.E.2d 937 (1986); FSLIC v. Superior Court, 180 Cal. App. 3d 336, 225 Cal. Rptr. 422 (1986), cert. denied, 107 S. Ct. 949 (1987); Union County Bank v. Knox Capital Corp., No. C/A 657 (Tem1. Ct.App. Apr. 18, 1986) (Westlaw, 1986 WL 4598); see also FSLIC v. Kemiedy, 732 S.W.2d 1 (Tex. Ct. App. 1986) (recognizing the general proposition enunciated in Hudspeth, but rejecting the argument that the FSLIC is entitled to redetermine the validity of claims that a court and jury have already adjudicated).

120. See Red Fox Indus. v. FSLIC, 832 F.2d 340, 341-42 (5th Cir. 1987); Coit Independence Joint Venture v. FirstSouth, F.A., 829 F.2d 563, 564 (5th Cir. 1987), cert. granted sub nom. Coit Independence Joint Venture v. FSLIC, 108 S. Ct. 1105 (1988); FSLIC v. Bonfanti, 826 F.2d 1391, 1393-94 (5th Cir. 1987), petition for cert. filed sub nom. Zohdi v. FSLIC, 56 U.S.L.W. 3196 (U.S. Aug. 5, 1987) (No. 87-255); Chupik Corp. v. FSLIC, 790 F.2d 1269, 1270 (5th Cir. 1986); see also Godwin v. FSLIC, 806 F.2d 1290, 1292-94 (5th Cir. 1987) (affirming decision of district court to deny motion for reconsideration of order granting dismissal of depositors' claim that their deposit was insured). But cf. Northshore Dev. v. Lee, 835 F.2d 580 (5th Cir. 1988). In Northshore, the court held that when a judgment has already becn entered prior to receivership, FSLIC can, on the basis of the Hudspeth doctrine, remove the action to federal court and have it dismissed. Id. at 593. The court, however, then noted that this does not imply that the district court must also vacate the judgment-FSLIC must choose between pursuing an appeal or securing dismissal and accepting the judgment. Id. (district court's denial of inotion to vaeate held not an abuse of discretion).

121. Lyons Sav. \& Loan Ass'n v. Westside Bancorporation, 828 F.2d 387 (7th Cir. 1987); see infra note 134.

122. See infra text accompanying notes $241-43$. 
edly transferred its assets negligently to a buyer, has held that section 1464(d)(6)(C) strips the district courts of jurisdiction to hear the action. ${ }^{123}$

2. Morrison-Knudsen: No Statutory Authority. After a year and a half of uncritical acceptance in federal courts, the Hudspeth doctrine received its first major setback at the liands of a panel of the Nintli Circuit im Morrison-Knudsen Co. v. CHG International, Inc. ${ }^{124}$ The case imvolved an insolvent, federally chartered thrift, Westside Federal Savings and Loan Association (Westside), for which the FSLIC had been appointed receiver. Westside was imvolved in five pre-receivership claims ${ }^{125}$ that the FSLIC, once it had been appointed Westside's receiver, souglit to have dismissed by the respective adjudicating and supervising district courts. The FSLIC's motions in the first four claims had been granted on the basis of the Hudspeth doctrine, but the supervising court in the motion mvolving the fifth claim had demed the FSLIC's motion. The Nintl1 Circuit ruled that there was no appellate jurisdiction in two of the claims, but reversed the orders of dismissal in the otler three.

The court was faced with challenges to both the FSLIC's statutory authority to adjudicate claims and its constitutional authority to do so given the provisions of article III of the United States Constitution. ${ }^{126}$ It engaged $\mathrm{m}$ an extensive analysis of the statutory framework and legislative history of the FSLIC, its powers under sections 1464(d)(6)(C) and 1729(d), and the regulations proinulgated by the FHLBB for processing claims in receiverships, and concluded that the legislation was not intended to confer adjudicatory powers on the receiver. ${ }^{127}$ While acknowledging that the FSLIC has been vested with full receivership powers, the Court rejected the assumption in the second Hudspeth opimion that these included adjudication.

123. See Fidelity Fin. Corp. v. FSLIC, 834 F.2d 741 (9th Cir. 1987).

124. 811 F.2d 1209 (9th Cir. 1987), petition for cert. filed sub nom. FSLIC v. Stevenson Assocs., 56 U.S.L.W. 3249 (U.S. Sept. 17, 1987) (No. 87-451). The Ninth Circuit opinion was written by Judge Sneed, joined by Judges Kennedy and Beezer. For a criticism of Morrison-Knudsen, see Huber, Enforcement Powers of Federal Banking Agencies, 7 ANN. REV. BANk1NG L. 123, 160-61 (1988) (describing the case as "a decision for the home team").

125. In the first claim it liad been impleaded as a third-party defendant, liaving allegedly guaranteed repayment of a loan in default for which anotlier thrift was being sued. In the second clain, a developer (CHG), to whom Westside had lent \$6.5 million, had declared bankruptcy; a co-participant in a loan agreement sought declaratory orders against Westside regarding the validity of the agreement, as well as damages and an order quieting title. The third and fourth claims against Westside involved contractual damages and equitable relief arising out of the bankruptcy of CHG. The fifth claim was filed by Westside itself in CHG's bankruptcy proceedings. Morrison-Knudsen, 811 F.2d at 1213.

126. See infra note 538 (quoting U.S. CoNST. art. III, $\$ 1$ in full).

127. See 811 F.2d at 1222 . 
The rock upon which FSLIC's arguments break is that a receiver's ordinary functions do not include adjudication. Judicial adjudication ... does not restrain or affect a receivership; it simply determines the existence and alnount of claims that a receiver is to honor in its eventual distribution of assets. ${ }^{128}$

The court buttressed its statutory interpretation by addressing the constitutional challenge as well. While declining to go so far as to hold the FSLIC's assertions of adjudicatory jurisdiction to be in violation of article III, the court was not persuaded that "the powers [the FSLIC] seeks easily survive Northern Pipeline scrutiny."129 This apprehension induced the court to read sections $1464(d)(6)(C)$ and 1729(d) so as to avoid the constitutional difficulty. Though the court recognized that Congress might, "with careful limitations like those governing FSLIC's adjudication of regulatory violations ... have crafted an adjudicatory jurisdiction for FSLIC in its receivership capacity that would pass constitutional muster," it found itself "convinced" that Congress had "not atteinpted to do so."130 In other words, the court, anticipating serious article III difficulties, read the statutory provisions upon which the FSLIC had rehed narrowly and rejected the FSLIC's assertion that they conferred an adjudicatory jurisdiction. ${ }^{131}$

The strict interpretive approach of the Ninth Circuit has subsequently been followed in a number of federal and state courts ${ }^{132}$ includ-

128. Id. at 1217 (citing, as did the first Hudspeth opinion, Morris v. Jones, 329 U.S. 545 (1947)); see supra note 108.

129. 811 F.2d at 1221 (referring to Northern Pipeline Constr. Co. v. Marathon Pipe Line Co., 458 U.S. 50 (1982), in which the Court had ruled the bankruptcy court scheine established by the 1978 Bankruptcy Act to be a violation of article III); see infra text accoinpanying notes 545-59.

130. $811 \mathrm{~F} .2 \mathrm{~d}$ at 1222 . Here the court was, in effect, merely applying the well-established principle that a statute should be construed, if possible, so as to save it from constitutional infirmities. See, e.g., Morrison v. Olson, 108 S. Ct. 2597, 2614 (1988); Commodity Futures Trading Comm'n v. Schor, 478 U.S. 833, 841 (1986).

131. The court did, however, recognize that a creditor might be required to exhaust her administrative remedies, and the three claims vere reinanded for the district court to address this issue. In deeiding whether to require the exhaustion of administrative remedies, the panel thought the trial court should consider whether: (i) resort to the administrative process would be futile; (ii) the administrative process was well-understood and well-developed; (ii) a prompt deeision as to all of the contested issues in the case was likely; (iv) an exhaustion requirement would be fair to the parties in light of their resources; (v) it would be fair to other parties in the case whose interests might be affeeted; (vi) the interests of judicial economy would be served by requiring exhaustion; and (vii) the agency deinonstrates that not requiring exhaustion would unduly imterfere with its functioning. See 811 F.2d at 1223-24.

132. See, e.g., Murdock-SC Assocs. v. Beverly Hills Sav., 815 F.2d 82 (9th Cir. 1987), petition for cert. filed sub nom. FSLIC v. Murdock-SC Assocs., 56 U.S.L.W. 3249 (U.S. Sept. 17, 1987) (No. 87-452); Hoinestead Sav. v. Life Sav. \& Loan Ass'n, 668 F. Supp. 1121, 1124 (N.D. Ill. 1987) (opinion vacated and removed from bound yolume, but appears in West's advance shects, see infra text accompanying notes 738-39); FSLIC v. Provo Excelsior Ltd., 664 F. Supp. 1405, 1416 (D. Utah 1987); Suminertree Venture III v. FSLIC, 742 S.W.2d 446, 453 (Tex. Ct. App. 1987); cf. FSLIC v. Frumenti Dev. Corp., 676 F. Supp. 957, 964 (N.D. Cal. 1988) (applying Morrison-Knudsen reason- 
ing, inost recently, the Supreme Court of Texas. ${ }^{133}$ On the other hand, Morrison-Knudsen has also been expressly rejected in favor of the $\mathrm{Hud-}$ speth doctrine by a number of other courts. ${ }^{134}$

\section{Glen Ridge: $A$ Violation of Article III. Even if statutory au-} thority to adjudicate does exist, neither the Morrison-Knudsen decision nor the decisions that have followed it have directly addressed the question whether such authority would be constitutional. The Constitution did, however, play a decisive role in the Texas court of appeals' decision in Glen Ridge I Condominiums, Ltd. v. Federal Savings \& Loan Insurance Corporation. ${ }^{135}$ The court, in two carefully reasoned opinions, ${ }^{136}$ concluded that the FSLIC had been granted statutory authority to adjudicate claims and that such authority was a violation of article III. Although the Texas Supreme Court declined to reach the constitutional issue, ${ }^{137}$ the court of appeals' decision is worth considering since it is the only one to date that has directly addressed underlying constitutional concerns.

ing in relnanding to a state court a claim involving only state-law rights and obligations, even though the FSLIC was a party); Peninsnla Fed. Sav. \& Loan Ass'n v. FSLIC, 663 F. Supp. 506, 509-11 (S.D. Fla. 1987) (distinguishing Hudspeth and partially applying principles enunciated in MorrisonKnudsen relating to exhaustion of remedies).

133. See FSLIC v. Glen Ridge I Condominiums, 750 S.W.2d 757 (Tex. 1988) (per curiam), aff' $g$ on other grounds 734 S.W.2d 374 (Tex. Ct. App. 1986). The decision of the court of appeals is discussed infra im text accompanying notes 135-40.

134. The Seventlı Circuit, in Lyons Sav. \& Loan Ass'n v. Westside Bancorporation, 828 F.2d 387, 391-95 (7th Cir. 1987), decided, in the absence of fuller argument, to follow Hudspeth. A number of district courts liave expressly chosen Hudspeth over Morrison-Knudsen. See, e.g., Peoples' Sav. \& Loan Ass'n v. First Fed. Sav. \& Loan Ass'n, 677 F. Supp. 1104, 1106 (D. Kan. 1988); Vernon Sav. \& Loan Ass'n v. Homes Int'1 Dev. Corp., 676 F. Supp. 247, 249 (S.D. Fla. 1988); Resna Assocs. v. Fmancial Equity Mortgage Corp., 673 F. Supp. 1371, 1377 (D.N.J. 1987); FSLIC v. Florida 100 Dev. Group, 670 F. Supp. 1577, 1580 (S.D. Fla. 1987); York Bank \& Trust Co. v. FSLIC, 663 F. Supp. 1100 (M.D. Pa. 1987), vacated and remanded, 851 F.2d 637 (3d Cir. 1988); Acquisition Corp. of Am. v. Sunrise Sav. \& Loan Ass'n, 659 F. Supp. 138, 140 (S.D. Fla. 1987); FSLIC v. Oldenburg, 658 F. Supp. 609, 611 (D. Utah 1987).

135. 734 S.W.2d 374 (Tex. C. App. 1986), aff'd on other grounds, 750 S.W.2d 757 (Tex. 1988) (per curiam).

136. In the court of appeals there were two unotions for rehearings. The first was granted and the court witlidrew its initial order affirming the trial court's dismissal of the claims against the FSLIC as receiver for Einpire Savings and Loan. It reversed the judgment of the trial court and filed an opinion on December 30, 1986. Then, through a new panel in which only one of the original three judges remained, the court demed the sccond inotion for reliearing and, on June 25, 1987, filed a supplemental opinion in support of its earlier decision, taking into account the opinions in Cominodity Futures Trading Comm'n v. Sclior, 478 U.S. 833 (1986), the most recent Supreme Court decision on the application of article III to administrative agencies. See infra text accompanying notes 589-95.

137. See FSLIC v. Glen Ridge I Condouniniums, 750 S.W.2d at 758-59 (affirming the court of appeals' decision on the ground that statutory authority was lacking). 
The Empire Savings and Loan Association (Empire) had partly financed real estate investment by Glen Ridge. When Empire went insolvent and the FSLIC was appointed its receiver, the FSLIC posted Glen Ridge's property for executive foreclosure pursuant to the relevant deeds of trust. Glen Ridge sued the FSLIC, Empire and the various trustees in state court for cancellation of the deeds of trust, damages, injunctive relief, and attorneys fees. Some claims were based on state law and others on federal law. The FSLIC, relying upon Hudspeth, had secured dismissal by the trial court of Glen Ridge's claims.

The court of appeals reversed the decision of the trial court insofar as the state-law claims were concerned, but affirmed the disimissal of the federal law claims. ${ }^{138}$ Confining itself to the state-law claims, the Texas court went even further than the Ninth Circuit had done in MorrisonKnudsen, ruling that sections 1464(d)(6)(C) and 1729(d) did indeed purport to grant adjudicatory jurisdiction and that, insofar as this jurisdiction included state-law claims, it violated article III. ${ }^{139}$ Motivating the court was the view that the adjudicatory scheme established by the FHLBB and the FSLIC fell far short of the criteria laid down by the United States Supreme Court for permissible departures from the literal provisions of article III. ${ }^{140}$

Prior to Glen Ridge a district court had rejected an article III challenge on the basis that "Northern Pipeline does not apply to administrative claims procedures," 141 a conclusion that seems clearly wrong. The holding in Glen Ridge itself has apparently not yet been fully considered in subsequent decisions involving the FSLIC. The article III question has, however, been raised in a few other cases, mcluding two currently pending before the Supreme Court. ${ }^{142}$ In each case the lower courts have treated the article III issue as not yet ripe for decision. ${ }^{143}$

138. 734 S.W.2d at 387.

139. See id. at $385-87$.

140. See infra text accompanying notes 568-73, 582, 590-95 (discussing these criteria).

141. See Lyons Sav. \& Loan Ass'n v. Westside Bancorporation, 636 F. Supp. 576, 581-82 (N.D. III. 1986), aff'd, 828 F.2d 387 (7th Cir. 1987).

142. See Thomes v. Equitable Sav. \& Loan Ass'n, 837 F.2d 1317, 1318 (5th Cir. 1988); Coit Independence Joint Venture v. FirstSouth, F.A., 829 F.2d 563, 564-65 (5th Cir. 1987), cert. granted sub nom. Coit Independence Joint Venture v. FSLIC, 108 S. Ct. 1105 (1988); American Fed. Sav. \& Loan Ass'n v. Westside Fed. Sav. \& Loan Ass'n, No. C-85-323-C, slip op. (W.D. Wash. Feb. 4, 1986), reprinted in Petition for Writ of Certiorari to the Umited States Court of Appeals for the Ninth Circuit at 38a, FSLIC v. Stevenson Assocs., 56 U.S.L.W. 3249 (U.S. Sept. 17, 1987) (No. 87451) [hereinafter Stevenson Petition], rev'd sub nom. Morrison-Knudsen Co. v. CHG Int'1, Inc., 811 F.2d 1209 (9th Cir. 1987), petition for cert. filed sub nom. FSLIC v. Stevenson Assocs., 56 U.S.L.W. at 3249 .

143. In Thomes v. Equitable Sav. \& Loan Ass'n, 831 F.2d 558 (5th Cir. 1987), a panel of the Fifth Circuit, while applying the Hudspeth doctrine insofar as the appellant's non-constitutional challenges were concerned, took note of the Ninth Circuit opinion in Morrison-Knudsen and as- 
4. Other Constitutional Issues. Various other constitutional challenges to the FHLBB and FSLIC procedures have also been raised (unsuccessfully so far). Of the most important, it has been argued that the grant of adjudicatory power to the FSLIC constitutes a violation of the nondelegation doctrine, 144 that it violates the seventh amendment by denying the right to a jury trial, ${ }^{145}$ and that it constitutes a violation of $d u e$ process, either because it deprives the creditor-claimant of a constitution:ally adequate hearing or because the FSLIC, as both receiver and insurer, has conflicting interests when adjudicating creditors' claims. ${ }^{146}$

In less important challenges, a hitigant has contended that the effect of applying the FSLIC's argument, in this case so as to nullify a prior attachment order in the creditor's favor, constitutes an unconstitutional taking of a compensable property right, ${ }^{147}$ and the question of sovereign immunity has been invoked several times, sometimes with success, by the FSLIC $\mathrm{m}$ order to buttress its assertion of exclusive jurisdiction to determine claims. ${ }^{148}$ The takings and immunity questions will not be examined in this article.

signed for oral argument the appellant's article III challenge to the FSLIC's exercise of adjudicatory jurisdiction. See id. at 559 . But the court subsequently dismissed the constitutional challenges as unripe because the plaintiffs had not exhausted their administrative remedies. Thomes, 837 F.2d at 1318.

144. See Baer v. Abel, 648 F. Supp. 69, 78 (W.D. Wash. 1986); First Am. Sav. Bank, F.S.B. v. Westside Fed. Sav. \& Loan Ass'n, 639 F. Supp. 93, 100 (W.D. Wash. 1986); American Fed. Sav. \& Loan Ass'n, No. C-85-323-C, slip op., reprinted in Stevenson Petition, supra note 142, at 49a-50; see also infra text accompanying notes 520-37.

145. See Coit Independence Joint Venture, 829 F.2d at 565; Baer, 648 F. Supp. at 77-78; see also infra text accompanying notes 638-57.

146. See Coit Independence Joint Venture, 829 F.2d at 564-65; FSLIC v. Florida 100 Dev. Group, 670 F. Supp 1577, 1583 (S.D. Fla 1987); Baer, 648 F. Supp. at 78; First Am. Sav. Bank, 639 F. Supp. at 100; Modern Supply Co. v. FSLIC, 50 Wasl. App. 194, 205, 748 P.2d 251, 257-58 (1987); see also infra text accompanying notes 601-37.

147. See, e.g., FSLIC v. Superior Court, 180 Cal. App. 3d 336, 343, 225 Cal. Rptr. 422, 425-26 (1986) (issue not ripe for review), cert. denied, 107 S. Ct. 949 (1987).

148. The contexts within which the claims of immunity have been made have varied, and the response of the courts has been mixed. See, e.g., Morrison-Knudsen Co. v. CHG Int'l, Inc., 811 F.2d 1209, 1214-15, 1222-23 (9th Cir. 1987) (FSLIC's sovereign immunity held waived by 12 U.S.C. $\$ 1729(b)(1)(B))$, petition for cert. filed sub nom. FSLIC v. Stevenson Assocs., 56 U.S.L.W. 3249 (U.S. Sept. 17, 1987) (No. 87-451); FSLIC v. Provo Excelsior Ltd., 664 F. Supp. 1405, 1417 (D. Utah 1987) (FSLIC's claim of adjudicatory power under 12 U.S.C. $\$ 1729$ (d) rejected along with claim of sovereign immunity); Baer v. Abel, 649 F. Supp. 25, 26-27 (W.D. Wash. 1986) (court declared that it had no subject matter jurisdiction to hear counterclaims against FSLIC where FSLIC acted as receiver and defendants liad not exhausted administrative remedies); Baer, $648 \mathrm{~F}$. Supp. at 75-77 (FSLIC lield immune from suit where FSLIC acted as receiver and plaintiffs did not bring claim in administrative forum); Colony First Fed. Sav. \& Loan Ass'n v. FSLIC, 643 F. Supp. 410, 414-15, $417-18$ (C.D. Cal. 1986) (FHLBB lield immune from suit challenging its appointment of a conservator; claims against individual officers banned where they acted in their official capacities); Modern Supply Co., 50 Wash. App. at 194, 748 P.2d at 251 (state court lacked jurisdiction over claim against FSLIC in its capacity as receiver); Summertree Venture III v. FSLIC, 742 S.W.2d 446, 


\section{The Liquidation Process}

\section{A. Options for Dealing With Troubled Thrifts.}

1. Sales and Financial Assistance. ${ }^{149}$ Thrifts are continuously monitored for safety and soundness by the examinations staff of the District Banks and the FHLBB's Office of Regulatory Pohicy, Oversight and Supervision. A primary concern is to try to prevent thrifts from failing in the first place; to this end the FSLIC has been granted extensive statutory powers to obviate outright receivership by lending assistance to troubled thrifts. ${ }^{150}$

When the FHLBB's Office of Regulatory Policy, Oversight and Supervision believes that a thrift is im imminent danger of default, it calls upon the FSLIC's Mergers and Acquisitions Division to determine if some method slort of receivership can be devised to rehabilitate the thrift or dispose of it in a manner that would protect all the parties involved. The FSLIC can provide loans or contributions to the troubled thrift, acquire its assets or habilities, financially assist its merger with another institution, consolidate it with otlers, or convert it from mutual to stock ownership im order to infuse it with new capital. ${ }^{151}$ The FSLIC lias also developed a Management Consignment Program, under which the thrift's management is replaced, pending the arrangement of a merger. ${ }^{152}$

454 (Tex. Ct. App. 1987) (FSLIC not, in this instance, a court-appointed receiver, and enjoys no judicial immunity); Glen Ridge I Condominiuns, Ltd. v. FSLIC, 734 S.W.2d 374, 384 (Tex. Ct. App. 1986) (case held not to involve automatically a "public right," thus justifying an administrative tribunal, simply because Congress waived FSLIC's immunity), aff'd, 750 S.W.2d 757 (Tex. 1988) (per curiam); cf. FHLBB v. Hague, 664 F. Supp. 245, 251 (W.D. La. 1987) (FSLIC and FHLBB enjoy sovereign immunity from suits sounding in tort and contract, and thus may not be sued directly), aff'd, 840 F.2d 14 (5th Cir. 1988); Kohlbeck v. Kis, 651 F. Supp. 1233, 1235 (D. Mont. 1987) (federal court jurisdiction over claims against FSLIC as receiver precluded until administrative procedure complete); Colony First Fed. Sav. \& Loan Ass'n, 643 F. Supp. at 416-17 (dealing with immunity under Federal Tort Clains Act).

149. See generally FHLB GUIDE, supra note 52, at 49-53; W. LovETT, supra note 30, at 131-44; E. SYMONS \& J. WHrre, supra note 40 , at 600-03 (bank regulation context).

150. See 12 U.S.C.A. § $1729(f)$ (West Supp. 1988).

151. See FHLB GuIDE, supra note 52, at 49; Williams, Thrift Acquisitions and Mergers: Statutory and Regulatory Framework and Current Issues, in OFFICE OF LEGAL EDUC., U.S. DEP'T OF JUSTICE, FINANCIAL INSTITUTIONS SEMINAR 715, 981-93 (1987). As this article went to press, the FHLBB published guidelines regarding FSLIC's policy on financial assistance. See FSLIC Statement of Policy and Criteria on Assistance to Insured Institutions Absent a Requirement for an Inımediate Merge Aequisition by a Third Party, 53 Fed. Reg. 30,714 (1988).

152. The Management Consignment Program is designed to minimize the ultimate cost of rehabilitation, merger or liquidation by facilitating FSLIC intervention where a thrift's assets are benig dissipated. See FHLB GuIDE, supra note 52, at 51-52; 1986 FHLBB ANN. REP. 28 (1987); Willianis, supra note 151, at 985-86. The program has been criticized by sone observers as ineffective. See Stevenson, A Good Idea Gone Sour: Savings Talent on Loan, N.Y. Tinies, June 8, 1988, at D1, col. 4, D9, col. 2 (city ed.). 
2. Receivership. If it is not feasible to rehabilitate or merge the insolvent thrift, the FHLBB places the thrift into receivership, and appoints, as appropriate, either the FSLIC or FDIC as receiver. ${ }^{153}$

Because of the need to avoid loss of confidence in the thrift industry as a whole, large thrifts have tended to be treated more favorably than their smaller counterparts. An example is the highly publicized assistance given recently by the FSLIC to the American Savings and Loan Association. ${ }^{154}$ Following the example of action taken the previous day by the FDIC to assist the subsidiary banks of the First Republicbank Corporation of Dallas, ${ }^{155}$ and in order to prevent a crisis of public confidence, the FHLBB announced that all deposits in American, regardless of size, would be guaranteed by the FSLIC. The effect of such a ineasure is not only to provide unlimited deposit insurance ${ }^{156}$ but also to keep open the doors of a thrift, thereby inamtaining the ordinary legal rights of creditors. If the Hudspeth doctrine is valid, this means that the rights of creditors depend significantly on the decision whether to assist a thrift or place it into receivership.

3. Federal Asset Disposition Association. In the process of assisting or liquidating a troubled thrift, the FSLIC frequently takes over thrift assets witl a view to inanaging and ultimately realizing them at their optimal value. To provide specialist attention to this function, the FHLBB chartered a private company, wholly owned by the FSLIC, in 1985. This is the Federal Asset Disposition Association, which has a tenyear cliarter. ${ }^{157}$

153. See infra text accompanying notes $166-75$.

154. See Nash, U.S. Aids Financial Corp. Unit, N.Y. Times, Mar. 19, 1988, at 17, col. 3 (national ed.).

155. See Nash, Large Texas Bank to get $\$ 1$ Billion in Federal Rescue, N.Y. Times, Mar. 18, 1988, at 1, col. 6 (national ed.).

156. Deposit insurance is limited by statute to $\$ 100,000$ per individual depositor. See 12 U.S.C. $\S 1724(\mathrm{~b})$ (1982).

157. See FHLB GuIDE, supra note 52, at 53-54; 1986 FHLBB ANN. REP. 29 (1987). The FADA, which Congress recently placed under the audit authority of the Comptroller General, see Competitive Equality Banking Act of 1987, Pub. L. No. 100-86, § 403, 101 Stat. 552, 609 (codified at 31 U.S.C.A. $\$ 9105$ (a) (West Supp. 1988)), has been subjected to severe criticism for having failed to achieve its purposes and for becoming insolvent itself. The House Banking Committee has recoinmended its abohtion. See H.R. 5094, 100th Cong., 2d Sess. $\$ 703$, introduced, 134 CoNG. REC. H5887 (daily ed. July 26, 1988); H.R. REP. No. 822, 100th Cong., 2d Sess., pt. 1, at 143 (1988);

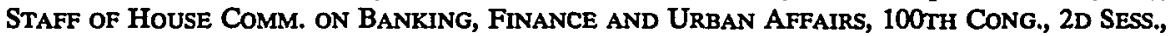
FEDERAL Asset Disposition Association: REPORT OF AN INQUIRY INTO ITS OPERATIONS AND Performance (Comm. Print), reprinted in 134 Cong. Rec. H2203-06 (daily ed. Apr. 21, 1988). 


\section{B. Placing Thrifts into Receivership.}

1. The Agencies Involved. When a thrift is federally insured, two of three federal agencies are involved in its supervision and receivership. ${ }^{158}$ The FHLBB exercises overall regulatory control. The FSLIC, which is always under the direction of the FHLBB, ${ }^{159}$ acts a receiver for the thrifts it insures. The FDIC, which is under the direction of the FHLBB when appointed the receiver of a federal thrift, ${ }^{160}$ acts as receiver for federal savings banks. ${ }^{161}$

The three agencies deal with three categories of thrifts. First are federal thrifts: those savings and loan associations and savings banks chartered, or converted to federal charter, by the FHLBB under the Hoine Owners' Loan Act ${ }^{162}$ and insured by either the FSLIC or the FDIC. Second are those state-chartered thrifts that are insured by the FSLIC subject to the direction of the FHLBB. Third are state-chartered 'savings banks, which can be insured by the FDIC without any FHLBB involveinent. ${ }^{163}$ Because the FDIC has only adopted the Hudspeth doctrine when it has been appointed receiver by the FHLBB, ${ }^{164}$ this article will consider only receiverships involving the first two categories.

\section{Power to Appoint Receivers.}

a. Federally chartered thrifts. In the case of federally chartered thrifts, the FHLBB has exclusive authority under the Hoine Owners' Loan Act to appoint a receiver. ${ }^{165}$ If the thrift is insured by the FSLIC,

158. State-chartered savings banks are a narrow exception in that, even if insured by the FDIC, they are not subject to the regulation of the FHLBB.

159. See 12 U.S.C. $\S 1725$ (a) (1982).

160. See infra text accompanying notes 179.81 .

161. See infra text accompanying notes 167-69.

162. See 12 U.S.C. $\$ 1464$ (a) (1982).

163. See 12 U.S.C. $\$ \S 1813(a), 1815(a)$ (1982).

164. See infra text accompanying notes 444-46.

165. See 12 U.S.C. $\$ 1464(d)(6)(A)-(B)$. The grounds for appointing a receiver (or conservator) are one or more of the following:

(i) insolvency in that the assets of the association are less than its obligations to its creditors and others, including its members; (ii) substantial dissipation of assets or earnings due to any violation or violations of law, rules, or regulations, or to any unsafe or unsound practice or practices; (iii) an unsafe or unsound conditions [sic] to transact business; (iv) willfull violation of a cease-and-desist order which has become final; (v) concealment of books, papers, rccords, or assets of the association or refusal to submit books, papers, records, or affairs of the association for inspection to any examiner or to any lawful agent of the Board[;] ...

... [or] in the event that (i) tle association, by resolution of its board of directors or of its members, consents to such appointinent, or (ii) the association is removed from membership in any Federal hoine loan bank, or its status as an institution the accounts of which are insured by the Federal Savings and Loan Insurance Corporation or the Federal Deposit Id. Insurance Corporation is terminated. 
the FSLIC must be appointed receiver. ${ }^{166}$ If, on the other hand, the thrift is a savings bank chartered under section 1464(0) and insured by the FDIC, ${ }^{167}$ the FDIC must be appointed receiver. ${ }^{168}$ Whereas the FHLBB has frequently appointed the FSLIC as a receiver, the FDIC has to date been appointed only once by the FHLBB. ${ }^{169}$

b. State-chartered thrifts. In the case of state-chartered thrifts that are insured by the FSLIC, the FHLBB has exclusive authority under the National Housing Act to appoint the FSLIC as receiver if the thrift is im a state of insolvency, if it is losing assets due to violations of law or unsafe or unsound practices, or if it is in an unsafe or unsound condition to transact business. ${ }^{170}$ The FSLIC then has all the receivership powers it enjoys as a receiver for a federal thrift. ${ }^{171}$

If, on the other hand, a state decides to place a state-chartered thrift into receivership and that thrift is insured by the FSLIC, the FSLIC may be appointed receiver by the state authority; if so, it possesses the same powers as those it enjoys as a federal receiver. ${ }^{172}$ The FHLBB will then "federalize" the receivership and assume supervisory control of the FSLIC as receiver. ${ }^{173}$ The legislation also leaves open the possibility that the state authority could place a thrift into receivership and not appoint the FSLIC as receiver, ${ }^{174}$ though in most cases the FHLBB would in any event be entitled to federalize the receivership and appoint the FSLIC. ${ }^{175}$

c. Exclusivity of the FHLBB's power of appointment and removal. The Home Owners' Loan Act authorizes the Board to appoint receivers without notice, ${ }^{176}$ but the association is entitled to challenge this appoint-

166. See 12 U.S.C. $\$ \S 1464$ (d)(6)(D), 1729(b)(1) (1982).

167. The FDIC is required to insure the accounts of federal savings banks. See 12 U.S.C. $\S 1726(\mathrm{a})(1)(1982)$.

168. See 12 U.S.C. $\S \S 1464$ (d)(6)(D), 1821(c) (1982).

169. Telephone interview with Judith L. Friedman, Associate General Counsel, FHLBB (Mar. 21, 1988); see 52 Fed. Reg. 49,204 (1987) (appointing the FDIC as receiver for Yankee Bank for Finance and Savings, FSB).

170. See 12 U.S.C. $\S \S 1729$ (c)(1)(B), 1464(d)(6)(A)(i)-(ii).

171. See 12 U.S.C. $\$ 1729$ (c)(1)(B)(i)(II).

172. See 12 U.S.C. $\S 1729(\mathrm{c})(1)(\mathrm{A})$.

173. See 12 U.S.C. $\$ 1729$ (c)(1)(B)-(c)(2); see also Fidelity Sav. \& Loan Ass'n v. FHLBB, 689 F.2d 803, 808-09 (9th Cir. 1982) (statutory requirements were satisfied for appointinent of the FSLIC as federal receiver), cert. denied, 461 U.S. 914 (1983).

174. See 12 U.S.C. $\$ 1729$ (c)(1). If the thrift is federally insured but the FSLIC is not appointed receiver, the FSLIC is required to pay the insurance and is entitled "(1) to bid for the assets of the insured institution in default, (2) negotiate for the merger of the insured institution or the transfer of its assets, or (3) make any other disposition of the matter as it may deein in the best interests of all concerned." Id.

175. See 12 U.S.C. $\$ 1729$ (c)(2).

176. See 12 U.S.C. $\S 1464(d)(6)(A)-(B)$. 
ment in a federal district court within thirty days. ${ }^{177}$ Subject to this exception, section $1464(d)(6)(C)$ provides that

no court may take any action for or toward the removal of any conservator or receiver, or, except at the instance of the Board, restrain or affect the exercise of powers or functions of a conservator or receiver. ${ }^{178}$

\section{Powers Upon Appointment.}

a. Powers conferred by statute. When the FHLBB was given regulatory responsibility over federal savings banks, the insuring and receivership role of the FDIC was retained. This created the possible anomaly that thrift receiverships might be governed, depending on which agency was appointed receiver, by two separate pieces of legislation: if the FSLIC were appointed, the National Housing Act would apply; if the FDIC were appointed, the Federal Deposit Insurance Act would apply. The FHLBB's rules relating to federal receiverships purport, however, to apply to both the FSLIC and the FDIC, ${ }^{179}$ and there is statutory language to support this view. ${ }^{180}$ Hence the powers of both the FSLIC and the FDIC acting under the supervision of the FHLBB will be treated as being the same. ${ }^{181}$ In any event, the general receivership practices of the FDIC are sufficiently similar to those of the FSLIC for present purposes to permit focus upon the FSLIC. ${ }^{182}$

177. See 12 U.S.C. $\S 1464(d)(6)(A)$.

178. 12 U.S.C. § 1464(d)(6)(C); see infra text accompanying notes 394-403.

179. See 12 C.F.R. § 549.1(b) (1988); cf. Conservators and Receivers, 50 Fed. Reg. 48,970, 48,973 (proposed Nov. 8, 1985) (to be codified at 12 C.F.R. $\$ 549.2$ ) (extending the application of the FHLBB's Hudspeth procedures to the FDIC).

180. The receivership power (to buy at its own sale) conferred upon the FSLIC as receiver by 12 U.S.C. $\S 1464(d)(6(D)$ is expressly stated to be applicable to the FDIC as receiver of a closed savings bank. And the powers conferred upon the FSLIC as receiver in 12 U.S.C. § 1729(b) are stated to be applicable to federal savings banks as well. Id.

181. In the only receivership in which it has been appointed by the FHLBB, see supra note 169, the FDIC has successfully secured the dismissal of at least one creditor's complaint from a federal district court on the basis of Hudspeth principles. See Rivers v. Yankee Bank for Fin. \& Sav., FSB, No. 88-0004-C (S.D. Ala. Mar. 21, 1988) (Westlaw, 1988 WL 81615) (single-page inemorandum decision). On the otler hand, a Massachusetts district court, in a fully reasoned opinion, has subsequently refused to recognize the FDIC's and FHLBB's claims to exclusive jurisdiction and has in effect rejected the Hudspeth doctrine for FDIC savings bank receiverships. See Tocci Corp. v. Yankee Bank for Fin. \& Sav., FSB, No. 87-3121-K (D. Mass. May 25, 1988) (Westlaw, 1988 WL 70344).

182. On FDIC receiverships, sec generally FDIC, THE FIRST FIFTY YEARS: A History OF THE FDIC 1933-1983 ch. 5 (1984); E. SYMONS \& J. WHITE, supra note 40, at 600-707; Skillern, Federal Deposit Insurance Corporation and the Failed Bank: The Past Decade (pts. 1 \& 2), 99 BANKING L.J. 233, 292 (1982); Note, Falling Banks: Creditor' Rights and the Distribution of Bank Assets, 7 Am. Rev. Banking L. 325 (1988); Comment, Bank Failure and the FDIC: A Survey of Legal Rights and Relationships of the Client and the Insolvent Bank, 18 TEX. TECH L. REV. 1193 (1987); Note, The Modified Payoff of Failed Banks: A Settlement Practice to Inject Market Discipline into the Commercial Banking System, 73 VA. L. Rev. 1349 (1987); Note, Creditors' Remedies Against the 
Under the National Housing Act, when the FSLIC is appointed as the receiver of a thrift, it is authorized as receiver

(i) to take over the assets of and operate such association;

(ii) to take such action as may be necessary to put it im a sound solvent condition;

(iii) to merge it with another insured institution;

(iv) to organize a new Federal association to take over its assets;

(v) to proceed to liquidate its assets in an orderly manner; or

(vi) to make such other disposition of the matter as it deems appropriate; whichever it deems to be in the best interest of the association, its savers, and the [FSLIC] ... 183

In addition, the receiver "shall pay all valid credit obligations of the association."184

Section 1729 supplements these powers and duties by granting a wide range of powers to the FSLIC to contract, form new federal thrifts, and lend financial and managerial assistance to existing ones. ${ }^{185}$ Subsection $1729(\mathrm{~d})$ also provides that:

[i]n connection with the liquidation of insured institutions, the [FSLIC] sliall have power to carry on the business of and to collect all obligations to the insured institutions, to settle, compromise, or release claims in favor of or against the insured institutions, and to do all other things that may be necessary in connection therewith, subject only to the regulation of the Federal Home Loan Bank Board, or, in cases where the [FSLIC] has been appoimted conservator, receiver, or legal custodian solely by a public authority having jurisdiction over the matter other than said Board, subject only to the regulation of such pubtic authority. ${ }^{186}$

FDIC as Receiver of a Failed National Bank, 64 TEx. L. REv. 1429 (1986). For differences between the powers of the FDIC and the FSLIC, see infra text accompanying notes 447-52.

183. 12 U.S.C. $\$ 1729$ (b)(1)(A). The legislation formerly required the FSLIC to act in the best interest of the "insured members of the association in default." National Housing Act of 1934, ch. 847, $\S 406(\mathrm{~b}), 48$ Stat. 1246, 1260. The amendment was contained in the Garn-St Germain Depository Institutions Act of 1982, Pub. L. No. 97-320, § 122(b), 96 Stat. 1469, 1481.

184. 12 U.S.C. $\$ 1729(\mathrm{~b})(1)(B)$.

185. See 12 U.S.C.A. $\$ 1729$ (a), (f) (West 1980 \& Supp. 1988).

186. 12 U.S.C. $\S 1729$ (d) (1982). The original section 1729 (d) was amended in 1982 by the Garn-St Germain Depository Institutions Act, Pub. L. No. 97-320, § 122(g), 96 Stat. at 1482-83. Section 1729 (d) had previously read:

In connection with the liquidation of insured institutions in default, the [FSLIC] shall have power to carry on the business of and to collect all obligations to the insured institutions, to settle, compromise, or release claims in favor of or against the insured institutions, and to do all other things that may be necessary in connection therewith, subject only to the regulation of the court or other public authority having jurisdiction over the matter.

National Housing Act, cl. 847, $\S 406$ (d), 48 Stat. at 1260 . The Garn-St Germam Act therefore substituted a new final clause emplrasizing the exclusive regulatory authority of the FHLBB when the FHLBB appoints the FSLIC as the receiver of a state thrift. The amendment was subject to an automatic sunset that came into effect on October 13, 1986, but it was restored in August 1987 by the Competitive Equality Banking Act of 1987, Pub. L. No. 100-86, § 509(a), 101 Stat. 552, 635 (1987). Whether the amendment makes any difference for our purposes is doubtful. Indeed, prior to 
b. The Board's regulatory powers. The Home Owners' Loan Act also grants to the FHLBB a general power to regulate the conduct of receiverships:

The Board shall have power to make rules and regulations for the reorganization, consolidation, liquidation, and dissolution of associations, for the merger of associations with associations or with any institutions the accounts of which are insured by the Federal Savings and Loan Insurance Corporation, for associations in conservatorship and receivership, and for the conduct of conservatorships and receiverships; and the Board may, by regulation or otherwise, provide for the exercise of functions by meinbers, directors, or officers of an association during conservatorship or receivership. ${ }^{187}$

The FHLBB has promulgated rules under this section, including the rules governing the Hudspeth process. ${ }^{188}$

4. Strategies Developed by the FSLIC. ${ }^{189}$ When it has been determined that a receivership is necessary, responsibility for the troubled thrift shifts to the Insurance Division of the FSLIC. A teain from the Division, acling on a written order of seizure of the FHLBB, moves to seize the institution in question. ${ }^{190}$ The operation is performed secretly and quickly im order to avoid public pamic or last-minule maneuvering by the thrift's manageinent to improve their own financial positions. The senior management is reheved of its duties immediately, the imstitution's doors are sealed, and the Insurance Division arranges a direct or indirect payout to insured depositors.

To conserve the insurance fund, the FSLIC tries to avoid a direct payout and liquidation wherever possible. In most cases it now uses its powers under section $1729(\mathrm{~b})(1)(\mathrm{A})^{191}$ to arrange "purchase and assumption transactions": 192 either a simple transfer of insured accounts to an-

the Garn-St Germain Act, section 1729(c)(3) had stated that "[i]n connection with the hquidation of any [state-chartered] institution, the language "the court or other public authority laving jurisdiction over the matter' in subsection (d) of this section shall mean the said Board." Bank Protection Act of 1968, Pub. L. No. 90-389, § 6, 82 Stat. 294, 296, repealed by Garn-St Germain Depository Institutions Act, Pub. L. No. 97-320, $\S 122,96$ Stat. at 1482; see Summertree Venture III v. FSLIC, 742 S.W.2d 446, 449 n.1 (Tex. Ct. App. 1987) (determination of whicl version of section 1729(d) applies is inconsequential); see also infra text accompanying notes 415-19.

187. 12 U.S.C. $\S 1464(d)(11) ;$ see infra text accompanying notes 404-06.

188. See infra text accompanying notes 203-05.

139. See generally FHLB GuIDE, supra note 52, at 52-53; Pfeiler, supra note 54, at 441-42 (discussing the FSLIC's adoption of "compreliensive administrative procedure for landling receiverships"); Williams, supra note 151, at 981-1002 (reviewing FSLIC techniques for resolving supervisory aequisitions and mergers).

190. See FHLB GuIDE, supra note 52 , at 52.

191. See supra text accompanying note 183 .

192. Thougl a well-establislied practice, see, eg., 12 C.F.R. $\S 569$ a.13 (1988), purchase and assumption transactions were first fully addressed and defined only in 1985, by the FHLBB's proposed rules relating to conservatorships and receiverships, see infra note 201. 
other institution (which will have bid for these at a slight premium), or an asset-backed transfer of accounts to a newly created mutual thrift. ${ }^{193}$ Where the transferee assumes all the habilities of the failed thrift, the problem of processing the claims of creditors disappears since creditors continue to enjoy their ordinary rights against the transferee institution. ${ }^{194}$ If some of the liabilities of the thrift in receivership are not transferred, however, the creditors will retain only a right of claim against tlie FSLIC as receiver for the failed thrift. ${ }^{195}$ Hence it is only where the FSLIC decides on a direct payout and liquidation, or on a partial purchase and assumption transaction, that the claims of creditors require resolution, and it is in this context that we turn to examine the administrative process devised by the FHLBB for liandling these claims.

5. Claims Procedures. Claims against failed thrifts are institutionally and procedurally separated at the FSLIC. ${ }^{196}$ Those made by in-

193. In 1986, for example, 8 of the 10 completed hquidations involved transfers of accounts rather than direct payouts. 1986 FHLBB ANN. REP. 27 table 5 (1987).

194. See, e.g., Bean v. Independent Am. Sav. Ass'n, 838 F.2d 739 (5th Cir. 1988). In Bean, a panel of the Fifth Circuit, per Judge Higginbotham (who wrote the opinion in Hudspeth), refused to extend the Hudspeth doctrine to creditors whose claims have been assumed by a new thrift. "[B]y transferring a hability or asset the FSLIC has determined that claims related to it should not be switched to the administrative track ...." Id. at 743.

195. When this happens, the remaining creditors are prejudiced in that they have to share in a distribution from a balance of assets that is, by virtue of the insolvency of the thrift, likely to be insufficient to meet their claims in full. See Pfeiler, supra note 54, at 442. Whether this preference is either authorized or fair is an open question.

Here, as in the initial decision whether to lend a thrift financial assistance or place it in receivership, see supra text accompanying notes 149-56, the decision is crucial to the rights of creditors.

The question of fairness to general creditors is also raised by the FHLBB's recent creation of an express depositor priority in certain purchase and assumption transactions and in the payment of claims from proceeds of certain thrift liquidations. The FHLBB has recognized the general principle that the claims of general creditors should rank equally with those of insured depositors. See Conservators and Receivers; Priority of Claims, 53 Fed. Reg. 25,129, 25,133 (1988) (to be codified at 12 C.F.R. $\S 569$ c.11(a)(0)). In the case of state-chartered thrifts chartered in states that have themselves enacted depositor-priority legislation, however, and in the case of claims against federally chartered thrifts that are competing with depositor claims booked or registered in states with such legislation, the FHLBB lias now established its own depositor-priority system. See Conservators and Receivers; Priority of Claims; Depositor Priority, 53 Fed. Reg. 30,665, 30,667-68 (1988) (to be codified at 12 C.F.R. $\S 569$ c.11(a)(6)). Given the parlous state of many insolvent thrifts, this new priority is likely in effect to extinguish general creditor claims altogether. See, e.g., FHLBB Resolution No. 88-378P (May 18, 1988) (appoimtment of receiver for Lamar Savings Association, Austin, Texas) (finding "the Association's general creditors' claims ... worthless" after applying the available proceeds to the satisfaction of the Association's secured and deposit habilities). Not only does this action severely stretch the FHLBB's asserted statutory authority, but it also seems to cast further doubt on the agency's ability to act as a genumely impartial adjudicator in the case of claims filed by general creditors.

196. Whereas it is governed by the FHLBB's Hudspeth procedures when processing the claims of uninsured creditors, the FDIC applies its own procedures in determining and paying the claims of insured depositors. Cf. Conservators and Receivers, 50 Fed. Reg. 48,992 (to be codified at 12 C.F.R. 
sured depositors are handled by the Insurance Division of the Office of the FSLIC (OFSLIC), ${ }^{197}$ and claims involving uninsured depositors and other creditors are processed by FSLIC as receiver of the failed institution in question, functioning through the FSLIC's Operations and Liquidations Division (with the assistance of a division of the Office of General Counsel). FSLIC Corporate would then itself become a claimant against the thrift in receivership (FSLIC Receiver). ${ }^{198}$

Though the procedures for processing the claims of insured depositors are fairly well-developed and well-codified, ${ }^{199}$ the procedures for processing uninsured and general creditor claims are still highly informal and in a state of development. This is partly because the increase in the range of creditor claims and the number of outright hquidations are fairly recent developments, ${ }^{200}$ and partly because judicial approval in Hudspeth for the administrative adjudication process came only in 1985. Late in 1985 the FHLBB published a set of proposed rules codifying the Hudspeth procedures, ${ }^{201}$ but these have not yet been converted into final rules. ${ }^{202}$ At present the procedures for processing claims are governed by an earlier set of rules, ${ }^{203}$ suppleniented by a set of unpublished guidelines, ${ }^{204}$ which were formerly made available to individual claimants by

$\S 569 \mathrm{c} .7(b)(4)$ ) (proposed Nov. 8, 1985) (exempting the FDIC from the application of FHLBB rules governing the processing of depositor claims). See generally 12 U.S.C. $\S 1821$ (1982).

197. See 12 C.F.R. $\S 500.20$ (a) (1988).

198. To avoid confusing these two capacities, the discussion will distinguisls "FSLIC Corporate" and "FSLIC Receiver."

199. See generally 12 C.F.R. pt. 564 (1988).

200. See supra text accompanying notes 52-88.

201. Conservators and Receivers: Proposed Rule, 50 Fed. Reg: 48,970 (to be codified at 12 C.F.R. pts. 547, 548, 549, 563, 569a, 569b, 569c) (proposed Nov. 8, 1985).

202. The FHLBB recently gave notice that proposed rules publisled by it and upon which no action has been taken by the Board will automatically lapse after six months. Regulatory Review Procedures, 53 Fed. Reg. 13,156 (1988). The expiration date for the Board's 1985 proposed Hudspeth rules was, however, extended to October 11, 1988. See Extension of Time Period for Board Action on Certain Outstanding Proposals, 53 Fed. Reg. 13,282 (1988).

Meanwhile, agency staff are currently preparing a further, shortened notice of proposed rulemaking for consideration by the Board. Telephone interview with Judith L. Friedman, Associate General Counsel, FHLBB (May 2, 1988). The Board has subsequently published a Supplemental Notice of Proposed Rulemaking, see Federal Savings and Loan Insurance Corporation; Receivers, 53 Fed. Reg. 21,474 (to be codified at 12 C.F.R. pts. 575, 576, 577) (proposed May 26, 1988), which incorporates the modifications made to informal procedures that have been in effect since July 1 , 1986. As this article was going to press, the Board apparently was planning to publish final rules that would conform with those published in the supplemental notice.

203. See 12 C.F.R. pts. 549, 569a (1988) (addressing federal thrift receiverships and state thrift receiverships). Section 549 applies to both the FSLIC and the FDIC. See id. § 549.1(b).

204. See Instructions for Filing Claims with the FSLIC as Receiver (Feb. 12, 1987) (FHLBB internal memorandum); Procedures for the Administration and Determination of Claims Filed with the FSLIC as Receiver (Feb. 12, 1987) (FHLBB internal memorandum); Procedures for the Processing and Determination of Administrative Appeals from Decisions of the FSLIC as Receiver (July 3, 1986) (FHLBB internal memorandum); Procedures for the Administration and Determination of 
receivers and which have now been published in inodified form as "Interim Procedures" and as revised proposed rules. ${ }^{205}$

\section{Depositor Claims.}

When an insured institution fails and the institution is placed in receivership, FSLIC Corporate is required to pay each insured account as soon as possible, either in cash or by ineans of a transferred account. 206 In practice, depositors' claims, whether insured or not, are processed by the Insurance Division, OFSLIC. Depositors, to the extent that their claims are uninsured, receive certificates of claims in hiquidation, copies of which are then provided directly to the FSLIC Receiver by the Insurance Division. ${ }^{207}$

1. Notice to Potential Claimants. Upon default of the insured institution, the FSLIC gives written notice to all insured members of the time and place of insurance payments and, if the failed institution has outstanding debts in the form of negotiable instruments, it must promptly pubhish a similar notice in a local newspaper. ${ }^{208}$ Insurance claims are processed by the staff of the Insurance Division. ${ }^{209}$

2. Initial Determinations. The FSLIC may require proof of claims and, where not satisfied as to the claim's validity, may require the insured member to secure a final determination of the claim in a court of competent jurisdiction. ${ }^{210}$ The general principles governing the Director's determination as to the validity of a claim to insured status are codified. ${ }^{211}$ For those claims accepted as valid and insured, the FSLIC must

Requests for Expedited Relief from Decisions or Threatened Actions of the FSLIC as Receiver (Mar. 1987) (FHLBB internal meinorandum). The latter three sets of guidelines are reprinted in Pfeiler, supra note 54, apps. C-E, at 490-510.

205. See Conservators and Receivers; Interim Procedures, 53 Fed. Reg. 13,105 (1988). These consist of: Procedures for the Administration and Determination of Claims Filed with the FSLIC as Receiver, 53 Fed. Reg. at 13,105-10 [hereinafter Claims Procedures]; Procedures for the Processing and Determination on Review of Determinations of the FSLIC as Receiver, id. at 13,1 10-12 [hereinafter Review Procedures]; Procedures for the Administration and Determination of Requests for Expedited Relief from Decisions or Threatened Actions of the FSLIC as Receiver, id. at 13,112-13 [hereinafter Expedited Relief Procedures]. The interim procedures lave since been incorporated in Federal Savings and Loan Insurance Corporation; Receivers, 53 Fed. Reg. at 21,474-82 (to be codified at 12 C.F.R. $\$ \S 575.1-577.5$ ). See id. at 21,475 (to be codified at 12 C.F.R. $\S 575.1$ ).

206. See 12 U.S.C. $\$ 1728($ b) (1982); see also 12 U.S.C.A. \$ 1729(b)(2) (West Supp. 1988) (obligating the FSLIC as receiver to pay the "insurance as provided in section 1728" (emphasis added)).

207. See 53 Fed. Reg. at 21,476 (to be codified at 12 C.F.R. \$ 575.6); Claims Procedures, supra note 205 , at 13,107 (para. II (D)).

208. 12 C.F.R. $\$ 564.1$ (a) (1988).

209. 12 C.F.R. $\$ 564.1$ (d) ("[t]he Director or Acting Director . . or his or her designee").

210. See 12 U.S.C. $\$ 1728(b)$.

211. 12 C.F.R. $\$ 564.2$. 
either pay out in cash ${ }^{212}$ or transfer the account of the insured ineinber to another insured institution. ${ }^{213}$

If all or a portion of the accountholder's account is determined to be uninsured, the Director inust give written notice of this determination and supply the accountholder with a "certificate of claim in hiquidation" froin the FSLIC "in its capacity as receiver." This enables the accountholder to share in the proceeds of the hquidation of the insured institution. ${ }^{214}$

3. Insurance Appeals ("Reconsiderations"). A dissatisfied accountholder may request reconsideration of the determination. ${ }^{215}$ Failure to do so is deemed acceptance of the initial determination. ${ }^{216}$ In practice, insurance reconsiderations are adjudicated by a meinber of the Adjudication Division of the Office of General Counsel..217

If the procedural requirements are coinplied with, the Director inust grant or deny the request ${ }^{218}$ and, within a further 180 days, must issue a decision on the inerits of the reconsideration (a "determination on reconsideration"). ${ }^{219}$ If a determination on reconsideration is not issued within this time the request for reconsideration is deened to have been denied.220

Since the handling of these requests was taken over by the Adjudication Division, the reversal rate stands at $8.2 \% .{ }^{221}$

4. Judicial Review. Actions must be brought within three years of the date of default or, if the clain was presented to the receiver and

212. 12 U.S.C. $\$ 1728(b)$.

213. That institution may either be one newly created in the same community, or an existing one. Id.

214. 12 C.F.R. $\$ 564.1$ (d)(2). The surrender and transfer to the FSLIC of an insured account shall subrogate the Corporation with respect to such insured account, but shall not affect any right which the insured member may have in the uninsured portion of his account or any right which he may have to participate in the distribution of the net proceeds remaining from the disposition of the assets of such association.

12 U.S.C.A. $\S 1729($ b)(2) (West Supp. 1988).

215. 12 C.F.R. $\$ 564.1(d)(3)$.

216. Id. $\$ \S 564.1(\mathrm{~d})(2),(\mathrm{d})(3)(\mathrm{iv})$.

217. This responsibility was transferred from the Regulations and Legislation Division of OGC, effective November 1, 1986. See Adjudication Division: Processing of Initial Insurance Determination Reconsideration Requests (undated FHLBB internal memorandum).

218. See 12 C.F.R. $\S 564.1(d)(3)(i i)(c)$.

219. Id. $\S 564.1(\mathrm{~d})(4)$.

220. Id.

221. That is, 34 cases of a total of 414 , involving decisions in favor of claimants to a total value of \$1,848,353. Telephone interview, supra note 202. 
denied, within two years of the date of denial.222 According to the Board's rules, an accountholder must exhaust the remedies already described; an initial determination for which the accountholder does not request reconsideration is taken to have been accepted, ${ }^{223}$ so failure to request reconsideration in a timely fashion will effectively prevent the holder from seeking review. 224

\section{Uninsured and Nondepositor Claims: The Hudspeth Process.}

1. Types of Claims Involved. The FHLBB's Hudspeth procedures are intended to encompass all types of claims that might be made against the thrift in receivership, with the exception of claims by insured depositors. 225 Under the FHLBB's interim and proposed rules, a "claim" is defined as "the assertion of a right to payment or other rehef" and includes demands for recoupment, setoff, security, priority, or preference, requests to foreclose or oppose foreclosure by the receiver on security property or assets, demands for interest, einployee wages, etc. ${ }^{226}$ "Claimants" include, "but [are] not limited to," holders of claims that appear in the thrift's books or records, or otherwise are known to the Receiver, owners of participation interests, borrowers, guarantors, secured creditors, lien holders and "[a]ny person(s) or entities seeking to recover civil money damages or equitable rehef against the association or the Receiver."22?

This encompasses a breathtaking range and variety of claims. In order to appreciate the comprehensive coverage of the Hudspeth procedures and the potential complexity of the claims involved, it is worth reviewing some of the of the types of claims that have been asserted in recent cases.

222. 12 U.S.C. $\S 1728$ (c). As to the applicability of the Hudspeth doctrine to the claims of insured depositors, see infra text accompanying notes 390-91.

223. 12 C.F.R. $\$ 564.1$ (d)(2).

224. Id. $\$ 564.1(d)(5)$. In Juguin v. FSLIC, 637 F. Supp. 1045, 1047 (W.D. Wash. 1986), this limitation was rejected as invalid. See infra note 390 (discussing Jugum, which has been vacated as moot).

225. See Federal Savings and Loan Insurance Corporation; Receivers, 53 Fed. Reg. 21,474, 21,476 (to be codified at 12 C.F.R. $\$ 575.6($ a)) (proposed May 26, 1988); Claims Procedures, supra note 205, at 13,107 (para. II(D)). Depositors with other claims are also claimants for the purposes of the rules. See 53 Fed. Reg. at 21,477 (to be codified at 12 C.F.R. $\$ 575.6$ (c)); Clains Procedures, supra note 205, at 13,107 (para. II(D)).

- 226. See 53 Fed. Reg. at 21,475 (to be codified at 12 C.F.R. $\$ 575.2(\mathrm{~h})$ ); Claims Procedures, supra note 205 , at 13,106 (para. I(B)(9)).

227. See 53 Fed. Reg. at 21,476 (to be codified at 12 C.F.R. $\S 575.2(\mathrm{~h})(3)$ ); Claims Procedures, supra note 205, at 13,106 (para. I(B)(10)). Secured creditors and owners of participation interests might enjoy some exemption from the published procedures. See 53 Fed. Reg. at 21,475 (to be codified at 12 C.F.R. $\S 575.1$ ); Supplementary Information, 53 Fed. Reg. at 13,105. 
a. Claims filed prior to receivership. Prior to being placed in receivership, a thrift might have initiated litigation against a former officer with a view to repudiating claims being inade against it for the continued payment of deferred compensation. ${ }^{228}$ Or it might liave launclied foreclosure proceedings agamst one of its inortgage loolders. ${ }^{229}$ The thrift might have found itself embroiled witll other thrifts in litigation involving a participatory loan agreement, litigation tliat could involve claims of breacli of contractual or otlier obligations ${ }^{230}$ and perhaps even cliarges of securities fraud and racketeering, ${ }^{231}$ antitrust violations, ${ }^{232}$ or race discrimination. ${ }^{233}$

b. Claims adjudicated prior to receivership. The validity of a creditor's claim iniglit already liave been judicially determined, yet the claim iniglit still be unpaid. A plaintiff iniglit have secured an as yet unexecuted judgment against the thrift. ${ }^{234}$ The parties might have entered into and already partly implemented a judicially supervised settlement agreement. ${ }^{235}$

c. Postreceivership litigation. When the FSLIC or the FDIC is appointed receiver, the FSLIC Receiver steps into the sloes of the thrift itself. The situation can then becoine even inore coinplex. The receiver will not only inherit the thrift's pre-existimg litigation responsibilities but

228. See, e.g., Hudspeth, supra note 103, 756 F.2d at 1096; see also supra text accompanying notes 98-117.

229. See, e.g., FirstSouth, F.A. v. LaSalle Nat'1 Bank, No. 86 C 10247 (N.D. Ill. Sept. 7, 1987) (Vestlaw, 1987 WL 16895).

230. See, e.g., Coit Independence Joint Venture v. FirstSouth, F.A., 829 F.2d 563 (5th Cir. 1987) (claims of usury, breach of fiduciary duty, and breach of duty of good faith and fair dealing), cert. granted sub nom. Coit Independence Joint Venture v. FSLIC, 108 S. Ct. 1105 (1988).

231. See, e.g., Lyons Sav. \& Loan Ass'n v. Westside Bancorporation, 828 F.2d 387 (7th Cir. $1987)$.

232. See, e.g., Red Fox Indus. v. FSLIC, 832 F.2d 340, 341 (5th Cir. 1987).

233. See, e.g., Resna Assocs. v. Financial Equity Mortgage Corp., 673 F. Supp. 1371 (D.N.J. 1987).

234. See, e.g., Homestead Sav. v. Life Sav. \& Loan Ass'n, 668 F. Supp. 1121 (N.D. Ill. 1987) (jury verdict for creditor of $\$ 6.2$ million, already paid over to clerk of court " in full satisfaction of the judgment' " prior to thrift being placed in receivership) (opinion vacated and removed from bound volume, but appears in West's advance sheets, see infra text acconipanying notes 738-39); First Fin. Sav. \& Loan v. FSLIC, 651 F. Supp. 1289 (E.D. Ark. 1987) (letter opinion entered by state court judge but judgment order not yet signed; FSLIC held estopped from hitigating claims); FSLIC v. Kennedy, 732 S.W.2d 1 (Tex. Ct. App. 1986) (affirming judgment entered in favor of creditor against thrift for recovery of certificate of deposit originally pledged as collateral in loan transaction subsequently breached by thrift); Union County Bank v. Knox Capital Corp., C/A657 (Tenn. Ct. App. Apr. 18, 1986) (Westlaw, 1986 WL 4598) (decree in favor of plaintiff issued prior to receivership of defendant; judgment entered after receivership but nunc pro tunc to date of opinion).

235. See, e.g., FSLIC v. Bonfanti, 826 F.2d 1391 (5th Cir. 1987), petition for cert. filed sub nom. Zohdi v. FSLIC, 56 U.S.L.W. 3196 (U.S. Aug. 5, 1987) (No. 87-255). 
might also generate new ones. For example the FSLIC Corporate might find itself repudiating and defending claims by depositors to the payinent of insurance. ${ }^{236}$ Or, as receiver, it might reject claims filed by general creditors, arising out of prior action by the failed thrift, and then have to defend a suit, or multiple suits, based on contract, tort or some other cause of action. ${ }^{237}$

The FSLIC Receiver might have to mitiate or pursue hitigation-for example, foreclosure proceedings, actions to recover receivership assets, or petitions to enjoin thrift directors from dissipating recoverable assets-as part of the liquidation proceedings. ${ }^{238}$ It might have to file claims, on behalf of the receivership, in other bankruptcy proceedings. ${ }^{239}$ Finally, the possibility of the FSLIC or the FDIC suing "itself" in two separate receivership capacities is not confined to the realm of the classroom hypothetical.240

d. Claims against the exercise of receivership powers. The FSLIC might even be sued in tort for the narmer in which it has conducted the

236. See, e.g., York Bank \& Trust Co. v. FSLIC, 663 F. Supp. 1100 (M.D. Pa. 1987), vacated and remanded, 851 F.2d 637 (3d Cir. 1988); Kohlbeck v. Kis, 651 F. Supp. 1233 (D. Mont. 1987); Baskes v. FSLIC, 649 F. Supp. 1358 (N.D. IIl. 1986).

237. See, e.g., FSLIC v. Provo Excelsior Ltd., 664 F. Supp. 1405 (D. Utah 1987) (multiple parties; securities fraud, federal and state RICO); Acquisition Corp. of Am. v. Sunrise Sav. \& Loan Ass'n, 659 F. Supp. 138 (S.D. Fla. 1987) (multiple parties; fraud and deceit, state RICO, breach of contract, civil theft); Kohlbeck, 651 F. Supp. at 1233 (negligence, fraud and racketeering); FSLIC v. Quality Inns, Inc., 650 F. Supp. 918 (D. Md. 1987) (counterclaim based on unjust enrichment and conversion of assets); Keller v. Antioch Sav. \& Loan Ass'n, 143 Iil. App. 3d 278, 492 N.E.2d 937 (1986) (false representation, breach of contract).

238. See, e.g., FSLIC v. Dixon, 835 F.2d 554 (5th Cir. 1987) (preliminary imjunction to prevent dissipation of possibly recoverable assets by directors); FSLIC v. Ticktin, 832 F.2d 1438 (7th Cir. 1987) (action against thrift directors for breach of fiduciary duties); Red Fox Indus. v. FSLIC, 832 F.2d 340 (5th Cir. 1987) (action by borrower to enjoin collection of debt by thrift and subsequent receiver); Blakely Airport Joint Venture II v. FSLIC, 678 F. Supp. 154 (N.D. Tex. 1988) (foreclosure); FSLIC v. Florida 100 Dev. Group, 670 F. Supp. 1577 (S.D. Fla. 1987) (foreclosure); FSLIC v. Hall Whispertrec Assocs., 653 F. Supp. 148 (N.D. Tex. 1986) (foreclosure); FSLIC v. Oldenburg, 658 F. Supp. 609 (D. Utah 1987) (complaint by assignment of rights from lead lender); FSLIC . Quality Inns, Inc., 650 F. Supp. 918 (D. Md. 1987) (action for recovery of receivership assets); Baer v. Abel, 649 F. Supp. 25 (W.D. Wash. 1986) (FSLIC intervention as plaintiff, asserting claims against former thrift officers for negligence, breach of fiduciary duty of care, breach of contract, violation of federal regulations, recovery of coinpensation, and contribution or indemnification); FSLIC v. Sajovich, 642 F. Supp. 74 (C.D. Cal. 1986) (action brought by FSLIC as conservator against thrift directors and independeut corporations for breach of fiduciary duty, neghigence, and money had and received); Glen Ridge I Condominiums, Ltd., v. FSLIC, 734 S.W.2d 374 (Tex. Ct. App. 1986) (foreclosure), writ denied, 750 S.W.2d 757 (Tex. 1988) (per curiam).

239. See, e.g., In re Miller Dev. Corp., 71 Bankr. 460 (Bankr. M.D. La. 1987).

240. See FDIC v. Umited States Nat'l Bank, 685 F.2d 270, 271 (9th Cir. 1981) (FDIC, as receiver for lending bank, brought action against itself as receiver for borrowing bank); see also Skillern, Federal Deposit Insurance Corporation and the Failed Bank: The Past Decade (pt. 2), 99 BANKING L.J. 292, 325 (1982) (discussing case in which bank that had failed and was placed under FDIC receivership sued another FDIC receivership). 
receivership. ${ }^{241}$ In these circumstances one should bear in mind that the exercise of the FSLIC's statutory powers are under challenge and not the validity of creditor claims against the thrift itself. The Federal Tort Claims Act ${ }^{242}$ and questions of sovereign immumity become relevant. ${ }^{243}$

\section{Structures and Procedures Developed by the FHLBB.}

a. Internal receivership arrangements. When the FHLBB resolves to appoint the FSLIC as receiver, the Director, OFSLIC, ${ }^{244}$ with the concurrence of the General Counsel, 245 designates a "Special Representative" to bear primary responsibility for the administration of the claims procedure, conduct the claims procedure, and determine the merits of claims. ${ }^{246}$ The Special Representative may then designate "Agents" "to perform certain functions, which include but are not limited to maintaiming a tracking system of the claims filed with the Receiver and performing an initial review of the Proofs of Claim submitted to the Receiver."247 The Special Representative, with the consent of the General Counsel, will also clesignate legal counsel, known as "Claims Counsel," "to represent the Receiver ... [and] to perform specified tasks" (set out in the Claims Procedures). ${ }^{248}$

In practice, ${ }^{249}$ the United States has been divided into five receiver-

241. See, e.g., Fidelity Fin. Corp. v. FSLIC, 834 F.2d 741 (9th Cir. 1987) (First Savings and Loan Association, which had been placed into receivership, brought action in state court against FSLIC, which had been appointed as receiver, challenging the transfer of assets); Kohlbeck v. Kis, 651 F. Supp. 1233 (D. Mont. 1987); Colony First Fed. Sav. \& Loan Ass'n v. FSLIC, 643 F. Supp. 410 (C.D. Cal. 1986) (FSLIC sued for damages it allegedly caused when thrift was placed in receivership); Glen Ridge I Condominiums, 734 S.W.2d at 387 (debtor of failed thrift brought action to enjoin FSLIC, as receiver of failed thrift, from foreclosing on its property).

242. Title IV, 28 U.S.C. $\$ \$ 2671-2680$ (1982) (current sections include minor amendments to original title IV).

243. For cases in which the FSLIC has attempted to argue that it enjoys sovereign immunity insofar as ordinary creditor claims are concerned, see supra note 148.

244. See 12 C.F.R. $\$ 500.20$ (1988). This structure is currently undergoing reorganization: the position formerly lield by the Director, OFSLIC, will be held by an Exeeutive Director of the FSLIC. Telephone interview, supra note 202.

245. See 12 C.F.R. $\S 500.17$. This may be an attorney in the Office of General Counsel designated by the General Counsel. See 53 Fed. Reg. at 21,476 (to be codified at 12 C.F.R. $\$$ 575.2(q)); Clains Procedures, supra note 205, at 13,107 (para. I(B)(18)).

246. See 53 Fed. Reg, at 21,476 (to be codified at 12 C.F.R. $\$ 575.2(z)$ ); Claims Procedures, supra notc 205, at 13,107 (para. I(B)(26)).

247. See 53 Fed. Reg. at 21,475 (to be codified at 12 C.F.R. $\$$ 575.2(c)); Claims Procedures, supra note 205 , at 13,106 (para. I(B)(4)).

248. See 53 Fed. Reg. at 21,476 (to be codified at 12 C.F.R. § 575.2(j)); Claims Procedures, supra note 205, at 13,107 (para. I(B)(11)); see also 12 C.F.R. $\$ 549.3(\mathrm{~b})(1)$ (1988) (receiver may einploy any attorney(s) for legal advice and assistance).

249. The information that follows vras obtained during an interview with Judith L. Friedinan, Director of the Adjudication Division of the Office of General Couusel, FHLBB, on October 21, 1987, and from internal FHLBB ineinoranda that Ms. Friedman inade available to the author. 
ship regions: the Northwest, West, South, Central and East. Each of these regions has a "Claims Coordinator" who manages the claims for receiverships within that region. Claims Coordinators are nonlawyer auxiliaries who provide administrative services to the Special Representatives and who bill each receivership for their time. In order to avoid premature agreement on payouts to creditors, they are presently required to be assisted by Claims Counsel from the moment a thrift is seized. In addition, the lead attorney from the Adjudication Division of the FHLBB's Office of General Counsel meets with Claims Counsel immediately prior to the takeover in order to explain the procedures and ensure the proper implementation of the claims process. The lead attorney remains available for consultation throughout the takeover process and is frequently available on site. In order to minimize conflicts of interest, Division attorneys are instructed not to discuss the particulars of any transaction that might give rise to a claim against the receivership and to absent themselves from any debriefing of the thrift officers by Claims Counsel and the FSLIC.

It is common for a team of Special Representatives to be appointed for each receivership. The team is headed by a Chief Special Representative, whio is also referred to as the "Managing Officer." This officer internally reviews and supervises the mitial determination of claims, though the degree of centralization varies from region to region. For example, the Southern region is very centralized, whereas the Western region is very decentralized. Special Representatives need not be lawyers, and in practice usually are not.

It is important to appreciate the informal, non-adversary and administrative quality of the claims determination process at the receivership level. Even Claims Counsel play the role of often confidential legal advisers to the Claims Coordinators and Special Representatives. They are private, fee counsel, occupying no formal adjudicative position in the receivership. It is also important to note that the FHLBB does not now regard the receiver, or any of its officers, as performing an "adjudicative" role at the initial claims determination phase; rather, the claims determination process assumes an adjudicative posture ouly at the administrative "review" stage. ${ }^{250}$

b. Notice to potential claimants. Promptly after the date of appointinent, the receiver must publish a notice directing all potential claimants to present their claims promptly. ${ }^{251}$ In the notice a final date

250. See infra note 275 .

251. See 12 C.F.R. $\S 549.4(\mathrm{a}) ; 53$ Fed. Reg. at 21,476 (to be codified at 12 C.F.R. $\S 575.3$ ); Claims Procedures, supra note 205, at 13,107 (para. II(A)). Claimants must be provided at least 90 
for the filing of proof of claims must be stipulated.252

c. Determinations by the receiver. The regulations require the receiver "[t]o allow any clain seasonably received and proved to its satisfaction."253

The interim Claims Procedures make provision for an "initial review" of claims. ${ }^{254}$ This review is performed by claims agents who enter the claims in a control $\log ^{25 s}$ and review them for proper filing. ${ }^{256}$ If a claim is not properly filed the claimant must be sent a "deficiency notice"257 and be given an opportunity to correct the deficiencies. 258 Once this has been done the claim is reviewed on the merits ${ }^{259}$ and the claimant must be notified whether the clain has bcen allowed or retained for further review. ${ }^{260}$

If the claim is "retamed for further review," the Special Representative will decide, according to the "nature of the task," the "issues involved in the claim" and, "where no significant legal issue is presented, the cost-savings mvolved," whether to assign reviewing responsibilities to an Agent, an Agent acting under the direction of a Claims Counsel, and/ or to a Clains Counsel.261

When conducting further review of the claim, the Special Representative may require the claimant to file additional information or documentation, make nonprivileged documents available for imspection and

days from the date of first publication of notice to present their claims, and the notice must be republished 30 and 60 days after first publication. See 12 C.F.R. $§ 549.4$ (a) (1988); 53 Fed. Reg. at 21,476 (to be codified at 12 C.F.R. $\$ \S 575.4,575.5$ ); Claims Procedures, supra note 205, at 13,107 (paras. II(B), (C)).

252. 12 C.F.R. $\$ 549.4$ (a) (1988); 53 Fed. Reg. at 21,476 (to be codified at 12 C.F.R. $\S 575.4$ ); Claims Procedures, supra note 205, at 13,107 (para. II(B)). This date must not be less than 90 days after the date of the first notice.

253. 12 C.F.R. \$ 549.4(b).

254. See 53 Fed. Reg. at 21,477 (to be codified at 12 C.F.R. $\$ \$$ 575.7-575.11); Claims Procedures, supra note 205, at 13,107-08 (paras. III(A)-(E)).

255. See 53 Fed. Reg. at 21,477 (to be codified at 12 C.F.R. $\$$ 575.8); Claims Procedures, supra note 205, at 13,107 (para. III(B)).

256. 53 Fed. Reg. at 21,477 (to be codified at 12 C.F.R. $\S 575.9$ ); Claims Procedures, supra note 205, at 13,107-08 (para. III(C)).

257. 53 Fed. Reg. at 21,477 (to be codified at 12 C.F.R. $§ 575.9(a)$ ); Claims Procedures, supra note 205, at 13,108 (para. III(C)(1)).

258. 53 Fed. Reg. at 21,477 (to be codified at 12 C.F.R. § 575.9(a), (b)); Claims Procedures, stupra note 205, at 13,108 (paras. III(C)(1), (2)).

259. 53 Fed. Reg. at 21,477 (to be codified at 12 C.F.R. $\$ \$ 575.9($ d), 575.10 ); Claims Procedures, stupra note 205, at 13,108 (paras. III(C)(4), (D)).

260. 53 Fed. Reg. at 21,477 (to be codified at 12 C.F.R. $\$ 575.11$ ); Claims Procedures, supra note 205, at 13,108 (para. III(E)).

261. 53 Fed. Reg. at 21,477 (to be codified at 12 C.F.R. $\$$ 575.12(b)); Claims Procedures, supra note 205 , at 13,108 (para. IV(A)(2)). 
copying, and file sworn responses to written questions. ${ }^{262} \mathrm{He}$ may also review "documents or other written information relevant to the claim in the custody of or subject to the control of any person or entity, mcluding the writing from any persons including the claimant or his employees, and inay obtain sworn statements ...."263 These form part of the administrative record ${ }^{264}$ and, to the extent that they are not privileged, may be inspected and copied by the claimant. ${ }^{265}$ The Special Representative may grant requests by the claimant to appear before an Agent, may require such an appearance, or may require the claimant to give statements, discuss the claim, and negotiate, subject to the Special Representative's approval, compromises of the claim. ${ }^{266}$ The claimant's oral statements must be reduced to writing, sworn to, and made part of the administrative record, but statements by both parties during settlement negotiations do not constitute part of the receiver's record. ${ }^{267}$ The Special Representative may require the claimant to submit a written legal memorandum on the issues; in such cases, this memorandum also becomes part of the record. ${ }^{268}$ An indexed record inust then be compiled and made available to the claimant for imspection and copying. ${ }^{269}$

Claims Counsel then consults with the Special Representative in order to provide "confidential, privileged legal advice as may be necessary to assist the Special Representative to reach a proposed determination with respect to the claim."270 The Special Representative must then prepare a memorandum of proposed findings of fact and conclusions of law, an analysis of the issues and a recommended proposed determination (proposed determination memorandum), as well as a proposed determination of claim in the form of proposed findings of fact and conclusions of law (proposed determination). Claims Counsel assists in this process, but any proposed determination ineinorandum he prepares that is super-

262. See 53 Fed. Reg. at 21,477-78 (to be codified at 12 C.F.R. $\S 575.13(\mathrm{~b})$ ); Claims Procedures, supra note 205, at 13,108 (para. IV(B)(2)).

263. 53 Fed. Reg. at 21,478 (to be codified at 12 C.F.R. $\$ 575.13$ (c)); Claims Procedures, supra note 205 , at 13,108 (para. IV(B)(3)).

264. Id.

265. See 53 Fed. Reg. at 21,478 (to be codified at 12 C.F.R. $\S 575.13(d)$ ); Claims Procedures, supra note 205, at 13,108-09 (para. IV(B)(4)).

266. See 53 Fed. Reg. at 21,478 (to be codified at 12 C.F.R. § 575.13(e), (f)); Claims Procedures, supra note 205, at 13,109 (paras. IV(B)(5), (6)).

267. See 53 Fed. Reg. at 21,478 (to be codified at 12 C.F.R. $§ 575.13(\mathrm{f})$ ); Claims Procedures, supra note 205, at 13,109 (para. IV(B)(6)).

268. See 53 Fed. Reg. at 21,478 (to be codified at 12 C.F.R. $§ 575.13(\mathrm{~g})$ ); Claims Procedures, supra note 205, at 13,109 (para. IV(B)(7)).

269. See 53 Fed. Reg. at 21,478 (to be codified at 12 C.F.R. § 575.13(i), (j)); Claims Procedures, supra note 205, at 13,109 (paras. IV(B)(9), (10)).

270. See 53 Fed. Reg. at 21,478 (to be codified at 12 C.F.R. § 575.13(k)); Claims Procedures, supra note 205, at 13,109 (para. IV(B)(11)). 
seded does not constitute part of the record. ${ }^{271}$ The proposed determination is then mailed to the claimant ${ }^{272}$ and, if no request for reconsideration is filed, it becomes the "receiver's determination."273

The proposed determination must advise the claimant of his right to file (within thirty days) a written "request for reconsideration." Such request must state the grounds of objection and may present proposed alternative findings and conclusions. The Special Representative must then promptly reply in writing, stating agreeinent or partial or complete disagreement. The request and reply becoine part of the administrative record. ${ }^{274}$ After consideration of the record, the receiver must issue a "receiver's determination,"275 signed by the Special Representative,276 and a "record of claim" stating the amount of the claim recognized.277

271. See 53 Fed. Reg. at 21,478-79 (to be codified at 12 C.F.R. $\S 575.13(l)$,(m)); Claims Procedures, supra note 205, at 13,109 (para. IV(B)(12)).

272. See 53 Fed. Reg. at 21,479 (to be codified at 12 C.F.R. $\S 575.13(n)$ ); Claims Procedures, supra note 205, at 13,109 (para. IV(B)(13)).

273. See 53 Fed. Reg. at 21,479 (to be codified at 12 C.F.R. $\$ 575.13(o)$ ); Claims Procedures, supra note 205, at 13,109 (para. IV(B)(14)) (formerly "initial determination").

274. See 53 Fed. Reg. at 21,479 (to be codified at 12 C.F.R. $§ 575.13(\mathrm{p})(5)$ ); Claims Procedures, supra note 205 , at 13,110 (para. IV(B)(15)(e)).

275. Formerly known as a "final determination." The term "fiual determination" came to be regarded as a misuoner because it suggested greater formality in the claims determination by the receiver than is really the case in practice. The alternative term, "receiver's determination," is thought to convey the nature of the receiver's decision more aceurately. Interview with Judith L. Friedman, Associate General Counsel, FHLBB, in Washington, D.C. (Oct. 21, 1987).

276. See 53 Fed. Reg. at 21,479 (to be codified at 12 C.F.R. $\S 575.13$ (d)); Claims Procedures, supra note 205, at 13,110 (para. IV(B)(15)(f)).

277. See 53 Fed. Reg. at 21,479 (to be codified at 12 C.F.R. $§ 575.13$ (s)); Claims Procedures, supra note 205 , at 13,110 (para. IV(B)(18)).

There is no rigid limit on the permitted time lapse betweeu a creditor's mitial filing of a claim and the determiuation by the receiver. The stipulated (and unstipulated) time limitations are as follows:

Action
Deficiency notice
Notice of allowance or retention
Further review:
- Further filing
- Written response
- Response to request
- Rdditional documents
- Receiver's inemoranduin
- Sequest for reconsideration
- Determination

Days
30
180
30
30
30
30
"prompt"
30
"prompt"
$?$

To Be Codified at
12 C.F.R. $\$ 575.9(\mathrm{a})$
Id. $\S 575.11$
Id. $\$ 575.13(\mathrm{~b})(1)$
Id. $\$ 575.13(\mathrm{~b})(3)$
Id. $\$ 575.13(\mathrm{~g})$
Id. $\$ 575.13(\mathrm{j})$
Id. $\$ 575.13(l)$
Id. $\$ 575.13(\mathrm{p})$
Id. $\$ 575.13(\mathrm{p})(4)$
Id. $\S 575.13(\mathrm{p})(6)$

Assuming that where maximum times are not specified the receiver's agents coinply within 30 days, the total tine lapse might be as long as 15 months. It appears that some determinations are taking even longer. See infra text accompanying notes 722-28. The interim and proposed rules permit a claimant to request expedited processing of a claim, but such processing is available only upon a showing of good cause, and even after such a showing, expedited processing reinains a matter "in the sole discretion of the Receiver." See 53 Fed. Reg. at 21,479 (to be codified at 12 C.F.R. $\$ 575.14$ ); Claims Procedures, supra note 205, at 13,110 (para. IV(C)). 
d. Administrative reviews. The FHLBB regulations contemplate "approval" by the Board of claims disallowed by the receiver. ${ }^{278}$ Interim provisions for "reviews" (formerly referred to as "appeals") of decisions of the receiver have been established. ${ }^{279}$ Though formally directed to the Board, the authority to hear these appeals has been delegated by the Board to the Director, OFSLIC, ${ }^{280}$ who has, in turn, subdelegated the authority to the Director of the Adjudication Division of the Office of General Counsel. ${ }^{281}$ Review determinations recommending the reversal, in whole or in part, of decisions by the receiver on the merits disallowing claims in excess of $\$ 5$ million must, however, be submitted to the Board itself for final determination, ${ }^{282}$ and the Adjudication Division will, in practice, submit other determinations to the Board that it beheves merit the Board's personal attention. ${ }^{283}$

When, on reconsideration, a receiver's determination has been issued, ${ }^{284}$ or if the claimant does not request reconsideration, ${ }^{285}$ the claimant is entitled to-and must, im order to preserve the right to judicial review-seek review of the determination by the Bank Board. ${ }^{286}$ Notice of the right to seek review inust be given to the claimant with the proposed determination by the receiver. ${ }^{287}$

Written notice of a request for review inust be filed with the Board within sixty days, ${ }^{288}$ and the request must contain a statement of the facts and arguments on which the request is based, a statement of the alleged factual and legal errors, references to the record and statement of

278. See 12 C.F.R. $\$$ 549.4(b), (d) (1988).

279. See 53 Fed. Reg. at 21,480 (to be codified at 12 C.F.R. $\S 576$ ); Review Procedures, supra note 205 , at 13,110-12 (paras. A-L).

280. FHLBB, Resolution No. 86-1161 (Nov. 17, 1986).

281. Delegation of Authority from the Director, Office of the Federal Savings and Loan Insurance Corporation to the Associate General Counsel for Adjudication to Perform Routine Procedural and Ministerial Functions Respecting the Implementation of Interim Claims Procedures. (Jan. 15, 1987) [hereinafter Delegation of Authority].

282. FHLBB, Resolution No. 86-1161, supra note 280.

283. Interview, supra note 275 .

284. See 53 Fed. Reg. at 21,479 (to be codified at 12 C.F.R. $\S 575.13(q)$ ); Clains Procedures, supra note 205 , at 13,110 (para. IV(B)(16)).

285. See 53 Fed. Reg. at 21,479 (to be codified at 12 C.F.R. $\S 575.13(o)$ ); Claims Procedures, supra note 205, at 13,109 (para. IV(B)(14)).

286. In practice, extensive legal support is provided to the Board by the General Counsel and the Director of the Adjudication Division. See supra text accompanying note 281 .

287. See 53 Fed. Reg. at 21,479 (to be codified at 12 C.F.R. $\$$ 575.13(q)); Claims Procedures, supra note 205, at 13,110 (para. IV(B)(16); 53 Fed. Reg. at 21,480 (to be codified at 12 C.F.R. $\S$ 576.2); Review Procedures, supra note 205, at 13,111 (para. B(1)).

288. See 53 Fed. Reg. at 21,480 (to be codified at 12 C.F.R. $\$$ 576.3(a)); Review Procedures, supra note 205 , at 13,111 (para. $\mathrm{C}(1)$ ). 
any new facts upon which the request is based. ${ }^{289}$ Unless more information is required, ${ }^{290}$ the request will be subjected to a "preliminary review" withm 60 days. ${ }^{291}$ Further evidence may only be introduced on a showing of good cause. 292

The record is then reviewed to determine whether it constitutes a sufficient basis for decision. If so, notice is given that the record is complete, and the record is closed. ${ }^{293}$ Within 180 days of closure of the record a decision on the merits of the review will be issued by the Board. ${ }^{294}$

e. Board review. In more complex cases, the Board, on the advice or request of the General Counsel, and "m its sole discretion," "may entertain oral argument, or other supplementary proceedings."295 Failure on the part of the Board to take such action, or failure to make a decision within the 180-day period, renders the receiver's determination the "decision of the Board." The Board will provide a written decision accompanied by its reasons ${ }^{296}$ and, to the extent that the claim is recognized, will provide the claimant with a "satisfaction of claim certificate."297

f. Judicial review. The Board's decision or maction constitutes final agency action for the purpose of judicial review. ${ }^{298}$ The Review Procedures purport to be a mandatory prerequisite to the availability of

289. See 53 Fed. Reg. at 21,480 (to be codified at 12 C.F.R. $\S 576.4($ a)); Review Procedures, supra note 205 , at 13,111 (para. D).

290. If so, more time may be required. See 53 Fed. Reg. at 21,480 (to be codified at 12 C.F.R. § 576.4(b)(2), (3)); Review Procedures, supra note 205, at 13,111 (para. D(2)).

291. See 53 Fed. Reg. at 21,480 (to be codified at 12 C.F.R. $\$ 576.4($ b)); Review Procedures, supra note 205 , at 13,111 (para. $\mathrm{D}(2)$ ).

292. 53 Fed. Reg. at 12,481 (to be codified at 12 C.F.R. § 576.5(b)); Review Procedures, supra note 205 , at 13,111 (para. E).

293. See 53 Fed. Reg. at 21,481 (to be codified at 12 C.F.R. $\S$ 576.5(a)); Review Procedures, supra note 205, at 13,111 (para. E(4)). The Board, however, reserves the right to "make its own findings of fact and conclusions of law based on the Administrative Record." 53 Fed. Reg. at 21,481 (to be codified at 12 C.F.R. § 576.5(e)).

294. 53 Fed. Reg. at 21,481 (to be codified at 12 C.F.R. § 576.7); Review Procedures, supra note 205, at 13,111 (para. $G(1)$ ). The decision is given in the name of the Board.

295. 53 Fed. Reg. at 21,481 (to be coclified at 12 C.F.R. § 576.7); Review Procedures, supra note 205 , at 13,111 (para. G). This must be done within 30 days of closure of the record, in which case the 180-day period is suspended until the supplementary proceedings are complete.

296. See 53 Fed. Reg. at 21,481 (to be codified at 12 C.F.R. § 576.8); Review Procedures, supra note 205 , at 13,111 (para. H).

297. See 53 Fed. Reg. at 21,481 (to be codified at 12 C.F.R. § 576.11); Review Procedures, supra note 205 , at 13,112 (para. $\mathrm{K}$ ).

298. See 53 Fed. Reg. at 21,481 (to be codified at 12 C.F.R. $\$ \S 576.8,576.9,576.11$ (b)); Review Procedures, supra note 205, at 13,111-12 (paras. H, I, K(2)). 
judicial review. ${ }^{299}$

3. "Expedited Relief." Entirely independent of the claims procedures just described are the provisions for expedited rehef froin decisions or threatened actions of the receiver. ${ }^{300}$ This procedure is designed to enable the FHLBB, through its delegate, to grant appropriate forms of equitable rehef. Since its inception the reinedy has expanded into a form of general injunctive relief available and applicable to both claimants and to the receiver itself (most frequently for correcting procedural irregularities)..$^{301}$ In practice requests for expedited relief are adjudicated, as in the case of creditor appeals and insurance appeals, by the Director of the Adjudication Division, under subdelegation from the Director, OFSLIC. ${ }^{302}$

Any person affected by "[a]ny decision or threatened action by the FSLIC as Receiver" may seek "extraordinary intervention by the Board outside of the routine claims process" by filing a "request for expedited relief." 303 An example of sucli a situation would be threatened foreclosure. ${ }^{304}$ The rules state that a request for expedited relief does not involve the merits of any claim and is solely a request to the Board to intercede on behalf of the petitioner. ${ }^{305}$

The request must contain a statement of the facts and issues, alleged factual and legal errors or omissions inade by the receiver, legal analysis, relevant docuinentation, an assessment of the likelihood of success on the merits of the underlying claim, and a stateinent of the probable imminent and irreparable harm that would occur if rehef were not granted. Notice of the request must be given simultaneously to the receiver. ${ }^{306}$

299. 53 Fed. Reg. at 21,480 (to be codified at 12 C.F.R. $\$ 576.3($ g)); Review Procedures, supra note 205 , at 13,111 (para. $C(7)$ ).

300. See 53 Fed. Reg. at 21,481-82 (to be codified at 12 C.F.R. $\S 577$ ); Expedited Relief Procedures, supra note 205 , at 13,112-13.

301. Interview, supra note 275 ; see also Pfeiler, supra note 54 , at $446-47$.

302. Delegation of Authority, supra note 281.

303. See 53 Fed. Reg. at 21,481 (to be codified at 12 C.F.R. § 577.2(b)); Expedited Relief Procedures, supra note 205, at 13,112 (para. A(2)). This must be done "withm five work days from the date of the Receiver's decision or action." The Board may extend the time limits for any expedited relief proceedings. See 53 Fed. Reg. at 21,482 (to be codified at 12 C.F.R. § 577.5); Expedited Relief Procedures, supra note 205, at 13,113 (para. D).

304. See 53 Fed. Reg. at 21,482 (to be codified at 12 C.F.R. $\$ 577.5$ )); Expedited Relief Procedures, supra note 205, at 13,113 (para. D).

305. See 53 Fed. Reg. at 21,482 (to be codified at 12 C.F.R. $\$ 577.3(a)$ ); Expedited Relief Procedures, supra note 205, at 13,112 (para. B(1)).

306. See 53 Fed. Reg. at 21,482 (to be codified at 12 C.F.R. $\$ \$ 577.2(e), 577.3(a)(7)$ ); Expedited Relief Procedures, supra note 205, at 13,112 (paras. A(5), B(1)(vii)). 
The receiver must file a response within five days ${ }^{307}$ and this response, together with the request and accompanying documentation, forms the basis for the administrative record on which the Board will make its determination. ${ }^{308}$ Any additional information required by the Board must be supplied "by a date certain." 309 The Board will issue a temporary restrainimg order, if necessary, mstructimg the receiver to stay its threatened action pending resolution of the request for expedited relief. ${ }^{310}$

The Board then issues a final decision with reasons, "as soon as practicable." 311

E. Overview of the Adjudicatory Structure.

The overall picture that emerges is as follows:

- At the primary decisionmaking level there is one agency, acting in two separate institutional capacities. For determinations involving insured deposits, the Insurance Division of FSLIC Corporate is responsible. For determinations involving uninsured deposits and general creditor claims, an agent of the FSLIC Receiver is responsible.

- At the Board level, the Director of the Adjudication Division of the FHLBB is in practice responsible for adjudicating disputes over both insurance and other clains, with the possibility of direct review and oral hearings by the Board.

- Finally, according to the Hudspeth doctrime, the determinations of the Board, with the possible exception of those involving insured depositor claims, ${ }^{312}$ are subject to limited judicial review under the APA.

307. See 53 Fed. Reg. at 21,482 (to be codified at 12 C.F.R. $\$$ 577.3(b)); Expedited Relief Procedures, supra note 205 , at 13,112 (para. B(2)).

308. See 53 Fed. Reg. at 21,482 (to be codified at 12 C.F.R. \$ 577.3(c)); Expedited Relief Procedures, supra note 205 , at 13,112 (para. $C(5)$ ).

309. See 53 Fed. Reg. at 21,482 (to be codified at 12 C.F.R. $\$$ 577.4(e)); Expedited Relief Procedures, supra note 205 , at 13,113 (para. $C(5)$ ).

310. See 53 Fed. Reg. at 21,482 (to be codified at 12 C.F.R. $\$ 577.4(\mathrm{~g})$ ); Expedited Relief Procedures, supra note 205, at 13,113 (para. C(7)). The stay will remain in effect "for a period of time sufficient to enable the party requesting relief to be provided with the Bank Board's Decision and an opportunity to seek judicial review of that Decision." See $53 \mathrm{Fed}$. Reg. at 21,482 (to be codified at 12 C.F.R. § 577.4(g)); Expedited Relief Procedures, supra note 205, at 13,113 (para. C(7)).

311. See 53 Fed. Reg. at 21,482 (to be codified at 12 C.F.R. § 577.4(d)); Expedited Relief Procedures, supra note 205, at 13,113 (para. C(4)).

312. The courts are divided on the question whether insured depositors are entitled to full, de novo judicial review or only Hudspeth. APA-type review. See infra note 390 and accompanying text. 


\section{Constraints Upon Agency Adjudication}

In order to provide a framework for evaluating the general Hudspeth procedures, it is necessary to review the statutory, constitutional and administrative law constramts within which the FHLBB must operate. Though not always recognized, these constraints share a subtle interdependency. For example, where, questions of constitutionality do not arise, it is enough that an agency's authority to act be merely implied in its governing legislation. ${ }^{313}$ But where the exercise of its powers appears to encroach upon the prescriptions of article III, it may be necessary for the agency's authority to be stated in fairly explicit terms. ${ }^{314}$ Second, a broad delegation of agency authority, which might once have been regarded as unconstitutional, ${ }^{315}$ will be accepted if there are adequate procedural safeguards in, and judicial scrutiny of, the exercise of that authority. ${ }^{316}$ Third, the courts might be more willing to tolerate agency authority that encroaches upon the preserve of article III if the exercise of that authority is subjected to the standards of due process ${ }^{317}$ and if there is adequate judicial scrutiny of the agency's action. ${ }^{318}$ Yet adequate judicial scrutiny might mandate the observance by the agency of stricter procedural standards than might ordinarily be required, either by the APA or by the requirements of procedural due process. ${ }^{319}$ And the application of the due process requirement of an impartial decisionmaker will vary according to the internal structural arrangennents of the agency. ${ }^{320}$ Finally, if the courts are satisfied that Congress has not violated article III in allocating decisionmaking power to an agency, they are also likely to accept that the seventh amendinent requirement of a jury trial is inappropriate in the context of agency adjudication. ${ }^{321}$

This interdependency suggests that Congress and the FHLBB, in devising a claims adjudication system, must take account of a whole network of statutory and constitutional restraints, none of which should be seen in isolation from the others. At the same time, the Board has the advantage of being able to secure a systein of adjudication during a period in which the Suprene Court has been extraordinarily deferential toward agencies. In the field of statutory interpretation, the Court has imitiated an era of deference toward the construction by agencies of their

313. See infra text accompanying notes 325-36.

314. See infra text accompanymg notes 596-98.

315. See infra note 514 .

316. See infra text accompanying notes 533-36.

317. See infra text accompanying notes $560,573$.

318. See infra text accompanying notes $555,573$.

319. See infra text accompanying notes 681-84.

320. See infra text accompanying notes 617-37.

321. See infra text accompanying notes 638-52. 
congressional mandates. ${ }^{322}$ In considering the role of agencies within the constitutional framework, it has settled upon an ad hoc balancing test for determining whether constitutional constraints have been breached. ${ }^{323}$ And in considering the application of the APA, it has been reluctant to enforce directly the observance of procedural standards beyond those expressly stipulated in the Act. 324

\section{A. Legislative Constraints: The Authority to Adjudicate.}

1. Statutory Interpretation in Modern Administrative Law. In 1984 the Supreme Court, in Chevron U.S.A. Inc. v. Natural Resources Defense Council, Inc., ${ }^{325}$ firmly indicated that courts were to defer to the construction by agencies of their statutory mandates whenever those mandates were not expressed in clear terms. Justice Stevens enunciated a two-stage test:

When a court reviews an agency's construction of the statute which it administers, it is confronted with two questions. First, always, is the question whether Congress has directly spoken to the precise question at issue. If the intent of Congress is clear, that is the end of the matter; for the court, as well as the agency, must give effect to the unambiguously expressed intent of Congress. If, however, the court determines Congress has not directly addressed the precise question at issue, the court does not simply impose its own construction on the statute, as would be necessary in the absence of an administrative interpretation. Rather, if the statute is silent or ambiguous with respect to the specific issue, the question for the court is whether the agency's answer is based on a permissible construction of the statute. ${ }^{326}$

In determining whether the FSLIC and the FHLBB possess statutory authority to adjudicate creditor claims, the Chevron analysis dictates that we should first ask whether the relevant legislation clearly addresses the issue. If this is the case then the inquiry is answered automatically and the adjudication power either exists or does not. If, on the other hand, the legislation is "silent or ambiguous," then we should defer to the agencies' view, provided this is "based on a permissible construction of the statute."

The trouble is that this two-stage test is deceptively simplistic and it sliould come as no surprise that subsequent application by the Court it-

322. See infra text accompanying notes $325-36$.

323. See infra text accompanying notes 510-18.

324. See infra text accompanying notes $489-92$.

325. 467 U.S. 837 (1984).

326. 467 U.S. at $842-43$ (footnotes omitted). 
self of the Chevron analysis has generated confusion and controversy. ${ }^{327}$ It is not immediately obvious how we might determine whether "the intent of Congress is clear." Will this depend upon whether Congress has expressed itself in "plain" and "unambiguous" language?328 Or will it depend upon whether, applying the traditional principles of statutory construction, the ineaning of otherwise unclear language becomes "clear"?329 If the words are "clear," must the court's analysis be confined to the "purely linguistic level,"330 or can one resort to legislative history in order to demonstrate that ostensibly clear words are in fact unclear, so that one should defer to the agency that has chosen to disregard thein?" As one commentator has recently observed, "one judge's plain meaning may be another's ambiguity."332

The Hudspeth court rehed on Chevron in accepting the FHLBB's construction of the FSLIC's powers under the Home Owners' Loan Act

327. See Hochberg, 'Two-Step' Method of Analysis: Still in Transition After Chevron, Nat'1 L.J., May 16, 1988, at 22, col. 1. But see Pierce, Chevron and its Aftermath: Judicial Review of Agency Interpretations of Statutory Provisions, 41 VAND. L. REV. 301, 302 (1988) (Chevron amounts to simple approach in coinplicated area); Starr, Judicial Review in the Post-Chevron Era, 3 YALE J. ON REG. 283, 283-84 (1986) (Chevron eliminated ambiguity in Clean Air Act Amendments of 1977); Starr, Sunstein, Willard, Morrison \& Levin, Judicial Review of Administrative Action in a Conservative Era, 39 ADMIN. L. REv. 353, 360 (1987) (Chevron provides clear, analytical framework for analysis); Note, Judicial Review of the Federal Banking Regulatory Agencies, 7 ANN. Rev. BANkING L. 365 (1988).

328. This is the view taken by the Court in Board of Governors v. Dimension Fin. Corp., 474 U.S. 361, 368 (1986) (Burger, C.J.) ("no amount of agency expertise-however sound nay be the result-can make the words 'legal right' mean a right to do something 'as a matter of practice;" " the intent of Congress was therefore "clearly expressed"). Justice Scalia expressed a similar view in his concurrence in INS v. Cardoza-Fonseca, 107 S. Ct. 1207, 1224 (1987) (criticizing the Court for engaging in an "ill advised" analysis of legislative history where the language of the law was "clear"). Cf. NLRB v. United Food \& Commercial Workers Umion, 108 S. Ct. 413, 426-27 (1987) (Scalia, J., concurring) (case was correctly decided 'only because 'the statute is silent or ambiguous' with respect to an issue relevant to the agency's administration of the law committed to its charge").

329. Cf. Cardoza-Fonseca, $107 \mathrm{~S}$. Ct. at 1220-22 (examining legislative history of statutory provisions in question in determining a "pure question of statutory construction").

330. United States v. Riverside Bayview Homes, Inc., 474 U.S. 121, 132 (1985). The Court sensibly characterized this approach as "simplistic." Id.

331. See Chemical Mfrs. Ass'n v. Natural Resources Defense Council, Inc., 470 U.S. 116 (1985). In Chemical Mfrs., the majority, after examining the legislative history of a statutory prohibition on "modifying" the requirements of the statute at issue, concluded that the prohibition was ambiguous enough to warrant deference to the construction placed upon it by the agency. Id. at 126-29. The dissent thought that the statute expressed the "clear intent of Congress." Id. at 135 (Marshall, J., dissenting).

332. Breger, Conference on Statutory Interpretation: The Role of Legislative History in Judicial Interpretation-Introductory Remarks, 1987 DUKE L.J. 362, 370. Of course, an investigation of legislative history does not guarantee that clarity will emerge. For a recent debate on the wellknown difficulties associated with the use of legislative history, sec Conference on Statutory Interpretation: The Role of Legislative History in Judicial Interpretation, 1987 DUKE L.J. at 361-86. 
and the National Housing Act. ${ }^{333}$ But Chevron has probably failed to simplify the task of identifying whether statutory authority for administrative claims adjudication exists or even whether the assumption that it does is a "permissible" construction of the legislation. The decision is better understood for present purposes as merely signaling a general, perhaps even necessary, ${ }^{334}$ disposition of deference toward agencies under circumstances in which there is no reason to mistrust their judgment. 335 The courts have proven accommodating in allowing significant remterpretations of banking regnlatory statutes (though not always in favor of the agencies) as the appropriateness of the legislation has changed over time. ${ }^{336}$ Hence, though we still need to examine the origin and evolution of the statutory provisions upon which the FHLBB and the FSLIC rely for their asserted jurisdiction, we should also bear in mind that statutory construction will be influenced by the fact that the courts are likely to display a benevolent attitude toward the banking agencies in their current difficulties.

2. Sections $1464(d)(6)(C), 1464(d)(11)$ and 1729(d): History, Context and Application. The FHLBB and the FSLIC rely upon three statutory provisions as constituting combimed authority for administrative claims adjudication. Section 1464(d)(11) supplies the general authority to enact rules governing the adjudication of claims. ${ }^{337}$ Section 1729(d)

333. See Hudspeth, supra note 103, 756 F.2d at 1103; see also Peoples' Sav. \& Loan Ass'n v. First Fed. Sav. \& Loan Ass'n, 677 F. Supp. 1104, 1106-07 (D. Kan. 1988); Keller v. Antioch Sav. \& Loan Ass'n, 143 IIl. App. 3d 278, 285, 492 N.E.2d 937, 941 (1980). In Morrison-Knudsen Co. v. CHG Int'l, Inc., 811 F.2d 1209, 1215 (9th Cir. 1987), petition for cert. filed sub nom. FSLIC v. Stevenson Assocs., 56 U.S.L.W. 3249 (U.S. Sept. 17, 1987) (No. 87-451), the court recognized that the FHLBB was entitled to Chevron deference but found that this deference could "not save an agency interpretation that is contrary to clear congressional purpose." For a discussion of the Hudspeth and Morrison-Knudsen courts' conflicting applications of Chevron, see Note, supra note 327, at 395-96.

334. See Strauss, One Hundred Fifty Cases Per Year: Some Implications of the Supreme Court's Limited Resources for Judicial Review of Agency Action, 87 CoLUM. L. REv. 1093 (1987). Strauss suggests that the Court has two good reasons for commanding deference to agencies' construction of their statutory mandates: the national responsibility of the agencies has a centralizing effect on the application of the law, and conflicts arising from independent review of legal questions in the circuits cannot be adequately resolved by the Supreme Court, given the limitations on its resources. Id.

335. Cf. Diver, Statutory Interpretation in the Administrative State, 133 U. PA. L. REv. 549 (1985) (advocating a presumption of deference toward agencies' construction of their governing statutes); Gerwin, The Deference Dilemma: Judicial Responses to the Great Legislative Power Giveaway, 14 HASTINGS CONST. L.Q. 289 (1987) (reviewing and criticizing the current mood of, and the ineonsistencies associated with, deference in all aspects of judicial review of agency action).

336. Cf. Langevoort, Statutory Obsolescence and the Judicial Process: The Revisionist Role of the Courts in Federal Banking Regulation, 85 MICH. L. REV. 672 (1987) (studying the behavior of courts faced with dilemma of interpreting obsolete statutes governing banking).

337. See supra text aecompanying note 187 (quoting $\$ 1464(d)(11)$ in full). 
supplies the FSLIC's power as receiver to adjudicate claims. ${ }^{338}$ And section $1464(\mathrm{~d})(6)(\mathrm{C})$ precludes the courts from "restraining" or "affecting" the receivership, thereby according to the FHLBB and, in turn, the FSLIC, exclusive authority to determine the disposition of creditor claims. ${ }^{339}$

In what follows, an attempt will be made to place these provisions in their proper context by tracing their genealogy. ${ }^{340}$ The conclusion will be that it is unlikely that either section $1464(d)(6)(C)$ or section 1729(d) was intended to confer claims adjudication authority on either the FHLBB or the FSLIC. On the other hand, it will be recognized that if the FHLBB were able to satisfy the many constitutional concerns involved, ${ }^{341}$ the general regulatory authority possessed by the FHLBB under section 1464(d)(11) might be sufficiently broad to provide statutory authority for the creation by the FHLBB of an administrative adjudication scheme.

a. Early practices. There were no federally chartered thrifts before 1933.342 State regulatory arrangements varied widely, though a fairly common feature was the vesting of receivership responsibility in the state agency responsible for the general supervision of thrifts, and the exemption of thrifts from the ordinary provisions pertaining to bankruptcy. ${ }^{343}$ On the other hand, it was also common practice to subject the hquidation and claims determination process to the supervision of a state court; ${ }^{344}$ indeed, this remains the case. ${ }^{345}$

During the nineteenth century there had, however, developed two forins of receivership applicable to financial institutions. The first was the traditional "equitable," or court-directed receivership, and the second was the statutory, or agency-managed receivership. ${ }^{346}$ The latter model reflected conscious efforts by particular states to impose a colier.

338. See supra text accompanying note 186 (quoting $\S 1729$ (d) in full).

339. See supra text accompanying note 178 (quoting $\S 1464(d)(6)(C)$ in full).

340. The most thorough judicial analysis to date is that contained in Summertree Venture III v.

FSLIC, 742 S.W.2d 446, 450-52 (Tex. Ct. App. 1987).

341. See infra text accompanying notes 658-84.

342. See supra text accompanying notes $40-42$.

343. See History OF BulldiNG AND LOAN, supra note 40, at 129.

344. See Pfeiler, supra note 54, at 466 n.119 (citing California, Minnesota and Pennsylvania statutes).

345. See, e.g., Ill. ANN. Stat. ch. 17, \ 3310-5 (Smith-Hurd 1981 \& Supp. 1988); IND. Code ANN. § 28-1-3.1-10 (Burns 1986); MAss. ANN. LAws ch. 167, §§ 28-29 (Law. Co-op. 1987); MD. FIN. INST. CODE ANN. §§ 9-702, 9-708 (1986); N.Y. BANKING LAW §§ 623-624 (McKinney 1971); TeX. Rev. Civ. Stat. ANN. arts. $342-811$ (Vernon 1973); Vt. Stat. ANN. tit. 8, § 1660 (1984).

346. See, eg., In re Union Bank, 176 A.D. 477, 481-82, 163 N.Y.S. 485, $488-89$ (1917). See generally Note, Statutory Control over the Dissolution of Building and Loan Associations, 35 CoLUM. L. REV. 265 (1935). 
ent scheme of banking regulation on financial institutions, and it was designed to replace any traditional equitable receivership that might otherwise be instituted in the event of a bank or thrift failure.

The evolution of the statutory receivership placed in question the supervisory jurisdiction of the courts that would otherwise have retained control over the receivership. The courts soon recognized that, as in other areas where the legislature had vested statutory powers in an officer or agency, it was not for them to gainsay the exercise of those powers by the legislature's delegate. So, for example, when the Comptroller of the Currency was einpowered to appoint receivers for failed national banks, the federal courts emphasized that, in the absence of abuses of power, ${ }^{347}$ the discretionary actions of the receiver (for example, decisions as to the realization and distribution of receivership assets) could not be modified by the courts. ${ }^{348}$ A plurality of the New York Appellate Division ennphasized that the receivership decisions of the New York Superintendent of Banks were not automatically subject to judicial proceedings. ${ }^{349}$

But this deference extended ouly to the discretionary statutory powers vested in receivers: where, on the other hand, the nondiscretionary question of the existence of a valid claim was concerned, the courts seemed to have no doubt that the decisions of statutory receivers, unlike those of some equitable receivers, ${ }^{350}$ were subject to de novo review. ${ }^{351}$ For example, it was recognized that creditors of national banks in receivership could establish the validity of their claims in court, ${ }^{352}$ and one

347. Review for abuse of power has always been contemplated. See, e.g., United States v. Knox, 102 U.S. 422, 425 (1880); Hulse v. Argetsinger, 12 F.2d 933, 936 (W.D.N.Y. 1926); Fifer v. Williams, 5 F.2d 286, 289 (9th Cir. 1925); Union Bank, 176 A.D. at 485, 163 N.Y.S. at 490-91.

348. See, e.g., Earle v. Pennsylvania, 178 U.S. 449, 454-55 (1900); Bushnell v. Leland, 164 U.S. 684, 685-86 (1897); Casey v. Galli, 94 U.S. 673, 677, 681 (1876); Kennedy v. Gibson, 75 U.S. (8 Wall.) 498, 505 (1869); Argetsinger, 12 F.2d at 935-36; In re Earle, 92 F. 22, 22 (C.C.E.D. Pa. 1899); Merrill v. First Nat'1 Bank, 75 F. 148, 152-53 (5th Cir. 1896); Altman v. McChintock, 20 F.2d 226, 231, 233 (D. Wyo. 1927); see also Barse, A Summary of the Procedure and Principles Relating to the Liquidation of National Banks in Receivership, FED. B.A.J., Oct. 1932, at 3, 4 ("Such liquidation is not subject to the supervision of either the state or federal courts, and is purely administrative in character.").

349. Union Bank, 176 A.D. at 483,163 N.Y.S. at 490.

350. See, e.g., State ex rel. Pitts v. Peter Cooper Bldg. \& Loan Ass'n, 74 Mo. App. 167 (1898) (refusing to conduct full de novo review of a court-appointed commissioner's determination of the validity of a creditor's clain, the commissioner being viewed as equivalent to a referee in chancery).

351. Execution of the claim, on the other hand, was not permitted. See, e.g., Cosmopolitan Trust Co. v. Suffolk Knitting Mills, 247 Mass. 530, 143 N.E. 138 (1924) (creditor could secure judgment as to the validity of its claim, but not set off); see also Barse, supra note 348, at 5 .

352. See, e.g., Earle, 178 U.S. at 455; Bank of Bethel v. Pahquioque Bank, 81 U.S. (14 Wall.) 383, 401 (1871); Kennedy, 75 U.S. (8 Wall.) at 506 (1869) ("The claims of creditors may be proved before the coinptroller, or established by suit against the association."); Schulenberg v. Norton, 49 F.2d 578, 580 (8th Cir. 1931) ("The statute provides an easy, speedy manner of determination of claims by permitting such to be presented to a receiver appointed by the Comptroller, but this is 
state court even recognized that, notwithstanding its clearly established deference towards receivers where the latter were exercising discretionary receivership powers, the actual priority of a creditor's claim (let alone its mere validity) was a matter justiciable in the courts. ${ }^{353}$

Thus the principle of limited, deferential judicial review with regard to statutory receiverships was well established long before the imposition of federal thrift receiverships. On the other hand, this deference was not extended to the nondiscretionary decisions of statutory receivers. As we liave already seen, the FSLIC and the FDIC are directed, when appointed as receivers of federal thrifts, to "pay all valid credit obligations"354 - a fornulation that does not obviously suggest discretion in the receiver. So prior financial receivership law, lowever progressive, offers hittle support to the FHLBB and the FSLIC in their efforts to establish exclusive autliority to adjudicate the validity of creditor claims.

b. Inception of federal regulation and deposit insurance. The first federal imvolvement was in response to the drain on savings that occurred during the Great Depression. ${ }^{355}$ Although thrifts reinained healthier than commercial banks, people were forced to draw on their savings as economic conditions deteriorated. This severely limited the flow of funds to housing. ${ }^{356}$ Congress therefore devised a sclieme whereby a system of regional "hoine loan banks" would be established for the purpose of providing an alternative source of funds to state thrifts. The scheme was embodied in the Federal Hoine Loan Bank Act, signed by President Hoover on July 22, 1932.357 The Federal Home Loan Bank Board was created for the purpose of cliartering and supervising the regional hoine loan banks, ${ }^{358}$ and state thrifts were ehgible to becoine members of the system by purcliasing stock in one of the hoine loan banks. ${ }^{359}$ The

quite different from limiting the ordinary and usual way of determining rights of creditors judicially."); Merrill, 75 F. at 153; Altman, 20 F.2d at 231-32; see also Barse, supra note 348, at 5:

If a claim is disallowed the creditor may file suit in either a state or a Federal court to establish his claim, but the judgment can do no more than establish the claim, and no execution can issue against the receiver, the time of payment being a matter vested in the adıministrative discretion of the Comptroller.

353. See Huey v. Rinehart, 116 W. Va. 309, 180 S.E. 263 (1935); see also Allen v. United States, 285 F. 678, 683-84 (1st Cir. 1923) (in a claim brought against an insolvent bank now run by the Commissioner of banks, federal court had jurisdiction to determine whether cash deposits created a trust in favor of the United States).

354. See supra text accompanying note 184.

355. For a valuable early account, see 5 FHLBB ANN. REP. 1-3 (1938).

356. See Barth \& Regalia, supra note 40 , at 124.

357. Ch. 522,47 Stat. 725 (codified as amended at 12 U.S.C. $\$ \S 1421-1449$ (1982 \& Supp. IV 1980.

358. 12 U.S.C. § 1437(a) (1982 \& Supp. IV 1986).

359. Where state law prohibited them from purchasing stock, they were nevertheless permitted to borrow from the home loan banks as nonmenibers. 12 U.S.C. § 1426 (1982). 
scheme provided thrifts with access to a greater pool of funds, but it also subjected them to federal regulation and supervision in that to remain eligible for membership in, or borrowing from, a hoine loan bank they had to comply with interest rate, hquidity and lending requirements imposed by the banks. ${ }^{360}$

As the economy deteriorated, however, increasing numbers of homeowners found themselves subjected to escalatimg interest rates and foreclosures. Moreover, numerous thrifts had failed and the availability of mortgage funds was drastically reduced or, in more than 1500 counties, had simply disappeared. ${ }^{361}$ These circumstances proinpted President Roosevelt, on April 13, 1933, to request emergency legislation from Congress, and this request was met, less than two months later, by the passage of the Home Owners' Loan Act of 1933. ${ }^{362}$

The Act created the Home Owners' Loan Corporation for the purpose of providing an emergency supply of inortgage funds in distress cases. ${ }^{363}$ It also facilitated, for the first time, the creation of federal savings and loan associations: the FHLBB was einpowered to charter mutual thrift associations, ${ }^{364}$ to allow state-chartered inembers of a home loan bank to convert to federal charter, ${ }^{365}$ and to regulate and provide for the liquidation of these associations, "mcludimg the power to appoint a conservator or a receiver to take charge of the affairs of any such association, and to require an equitable readjustment of the capital structure of the same." ${ }^{366}$ Federal thrifts were to be strictly confined in their operations to narrow geographic locahities. ${ }^{367}$

At this stage no guidance was given by Congress as to how thrifts should be liquidated. The FHLBB was inerely given the general authority already quoted. The legislative history is devoid of any reference to the FHLBB's power to hquidate federal thrifts, the primary conceru of the legislators being the creation of the Loan Corporation and the provision of funds for home mortgages. ${ }^{368}$ This is hardly surprising: not only

360. See 12 U.S.C. $\S 1431$.

361. See H.R. Rep. No. 55, 73d Cong., 1st Sess. 2 (1933); Barth \& Regalia, supra note 40, at 124 $\&$ n.10.

362. Ch. 64, 48 Stat. 128; see Fidelity Fed. Sav., \& Loan Ass'n v. De la Cuesta, 458 U.S. 141, 163 n.18 (1982).

363. Home Owners' Loan Act, ch. $64, \S 4,48$ Stat. at 129-32, repealed by Act of June 30,1953 , ch. $170, \S 21,67$ Stat. 126 (codified at 12 U.S.C. $\$ 1463$ ).

364. Home Owners' Loan Act, ch. 64, § 5(a), 48 Stat. at 132.

365. Id. §5(i), 48 Stat. at 134.

366. Id. $\S 5(\mathrm{~d}), 48$ Stat. at 133 .

367. See id. $\S 5(\mathrm{c}), 48$ Stat. at 132 (confining thrifts to a 50-mile geographic limit, with limited exceptions).

368. See, e.g., S. Rep. No. 91, 73d Cong., 1st Sess. (1933); H.R. ReP. No. 55, 73d Cong., 1st Sess. (1933); H.R. CONF. ReP. No. 210, 73d Cong., 1st Sess. (1933). 
was the legislation rushed through Congress, ${ }^{369}$ but the nature of the thrift industry as it was then would hardly have suggested complicated claims determinations. The overwhelming bulk of thrift creditors would have been depositors, for whom records would have been well-documented. Besides, the systems of state regulation provided ample precedents toward which a new federal agency might look for guidance as it developed its own system of regulation. Hence it is reasonable to assume that Congress would have regarded hquidation as a concern best left to the FHLBB. ${ }^{370}$

The provision of emergency, low-interest funds for hoine inortgages actually exacerbated the difficulties of many thrifts. ${ }^{371}$ This induced Congress to enact the National Housing Act in 1934. ${ }^{372}$ Title IV of the Act ${ }^{373}$ imstituted a system of deposit insurance, largely along the lines of the system recently introduced for banks, ${ }^{374}$ and created the FSLIC as an agency to operate under the direction of the FHLBB. ${ }^{375}$ Congress had two objectives in passing the Act: first, to protect the small depositor; ${ }^{376}$ but, perhaps even more importantly, to serve the vital pubhc, monetary function of restoring "to the community, as quickly as possible, circulating inedium destroyed or made unavailable as a consequence of bank failures."377

c. Introduction of section 1729(d). In the National Housing Act Congress was a httle more specific about hquidations: the FSLIC was required to pay out insured depositors or transfer their accounts, im the event of a thrift account, ${ }^{378}$ and was required to act as receiver if the defaulting thrift was a federal one. ${ }^{379}$ As receiver the FSLIC was re-

369. See Fidelity Fed. Sav. \& Loan Ass'n v. De la Cuesta, 458 U.S. 141, 163 n.18 (1982).

370. See infra text accompanying notes 522-24; cf. Fahey v. Mallonee, 332 U.S. 245, 250 (1947) (recognizing the constitutionality of broad delegation to FHLBB in view of the "accumulated experience of supervisors, acting for many states under various statutes" that "lias established well-defined practices for the appointment of conservators, receivers and liquidators").

371. See Bartli \& Regahia, supra note 40, at 124.

372. Cl. 847,48 Stat. 1246 (codified as amended at 12 U.S.C. $\S \S 1701-1750 \mathrm{~g}$ (1982)).

373. Id. $\S \S 401-407,48$ Stat. at 1255 (codified as amended at 12 U.S.C. $\S \S 1724-1730(\mathrm{~g})$ ).

374. Banking Act of 1933 , cl. 89,48 Stat. 162 (codified as amended at 12 U.S.C. $\S \S 1811-1832$ (1982)); see supra text accoinpanying notes $26,43$.

375. National Housing Act, ch. $847, \S 402,48$ Stat. at 1255 (codified as amended at 12 U.S.C. $\S 1725$ (1982)).

376. See, e.g., 80 CONG. REC. 11,200 (1934) (statements of Reps. Williams and Dirksen).

377. Golembe, The Deposit Insurance Legislation of 1933: An Examination of its Antecedents and its Purposes, 75 PoL. SCI. Q. 181, 189 (1960). The autlor is referring to bank deposit insurance, but the same reasoning applies to thrift deposit insurance.

378. 12 U.S.C. $\$ 1728(b)$ (1982).

379. 12 U.S.C. $\$ 1729$ (b) (1982). 
quired to pay "all valid credit obligations" of tlie failed thrift.380 And it was in this Act that the original provision codified at 12 U.S.C. section 1729(d) was first introduced. ${ }^{381}$ Except for amendments clarifying the exclusive regulatory authority of the FHLBB over the FSLIC when the latter acts as receiver of a state thrift, the provision lias reinained basically unchanged. ${ }^{382}$

Once again, lowever, the legislative history adds little to tlie text of the Act. The overall plan of deposit insurance was obviously very close to that of the bank deposit insurance sclieme that had been created exactly one year before. ${ }^{383}$ In liearings before the House Committee, the General Counsel of the FHILBB described the insurance payout options of the FSLIC as receiver as being "substantially the saine thing as in the Bank Deposit Insurance Corporation legislation," 384 and in the House Cornunittee Report the legislation is described as liaving inade "[a]dequate provision ... for the liquidation of insured institutions somewhat similar to the plan for the liquidation of banks whicls are under Federal deposit insurance."385 Beyond these sparse hints that the practice of the FDIC was to be the inodel, ${ }^{386}$ the legislative history casts no furtlier light on the ineaning of the words "settle, coinpromise or release," "do all otlier things that inay be necessary in connection therewith," and "subject only to the regulation of the court or other public authority liaving jurisdiction over tlie inatter," that liave been used in section 1729 (d). ${ }^{387}$

380. Id. The Act draws no distinction between FSLIC Corporate and the FSLIC Receiver, since the same provision also requires FSLIC Corporate to pay the failed thrift's insurance upon being appointed receiver. See 12 U.S.C. $\$ 1729$ (b)(2) (Supp. IV 1986).

381. National Housing Act $\S 406(d), 12$ U.S.C. $\$ 1729$ (d) (1982) (quoted as originally enacted supra at note 186). The Fifth Circuit in Hudspeth incorrectly assumed that section 1729(d) had been introduced by the Bank Protection Act of 1968. For background on the Bank Protection Act, see infra text accompanying notes 407-12. See Hudspeth, supra note 103, 756 F.2d at 1101 n.2. The court thus wrongly assumed that this provision was introduced in the context of legislation concerned with reducing delay and mininizing costs in FSLIC receiverships. The effect of the 1968 Act was nierely to extend seetion 1729 (d) to receiverships involving state-chartered thrifts. See Pfeiler, supra note 54, at 440-41.

382. See supra note 186; see also infra text accoinpanying notes 415-19.

383. See supra note 43.

384. StafF of House COMm. on 13anking \& CuRrency, 73D Cong., 2D Sess., Hearings on H.R. No. 9620, Housing ACT Amendments of 1934, at 15, 18 (Comm. Print 1934) (stateinent of Horace Russell, General Counsel, FHLBB).

385. H.R. REP. No. 1922, 73d Cong., 2d Sess. 4 (1934); see also 80 CoNG. REc. 11,199 (1934) (statement of Rep. Williams) ("[t]his plan is analogous to the bank-deposit insurance provided at the last session").

386. See infra text acconipanying notes $430-48$.

387. Nor are the FSLIC's early reports much help. In its first annual report, the FSLIC merely describes its receivership duties as including the responsibility to "liquidate [federal savings and loan associations] in a normal manner." 3 FHLBB ANN. REP. 73 (Jan. 1-June 30, 1935). A perusal of the early annual reports reveals that the FSLIC has always attenupted to avoid liquidation where 
d. Judicial determination of disputed insurance claims. In the Housing Act of $1954^{388}$ Congress amended both the National Housing Act and the Home Owner's Loan Act. A statute of limitations was placed upon actions to enforce deposit imsurance claims against the FSLIC. ${ }^{389}$ This is significant for our purposes because, though the FSLIC has inade soine headway with the Hudspeth doctrine even in this context, ${ }^{390}$ the statutory reference to judicial challenges would seem to indicate that, at least in the case of claims involving imsured depositsthe most likely type of claim in a thrift hquidation, given the restricted nature of thrift business at that time-Congress did contemplate the judicial determination of claims where their validity was in dispute. ${ }^{391}$

possible and, if liquidation is inevitable, to minimize the costs of liquidation. See, e.g., 8 FHLBB ANN. ReP. 101, 120 (July 1, 1939-June 30, 1940); 9 FHLBB ANN. REP. 128 (July 1, 1940-June 30, 1941). But references to the process of liquidation were always couched in vague terms.

On the other hand, some indication that the FHLBB and FSLIC regarded the judicial process as the appropriate means of resolving disputed creditor claims is evident from the fact that in early receivership litigation the FSLIC made no objection to the courts' jurisdiction to determine the validity of claims. See, e.g., Deep Rock Oil Corp. v. Salisbury, 130 F.2d 387 (8th Cir. 1942) (deciding dispute between bankrupt oil corporation and savings and loan for which FSLIC had been appointed receiver); Community Fed. Sav. \& Loan Ass'n v. Fields, 128 F.2d 705 (8th Cir. 1942) (deciding employment contract dispute between employee and savings and loan for which FSLIC was the appoimted receiver); Town of Texhoma ex rel. Versluis v. Neild, 9 F.R.D. 739 (W.D. Okla. 1943) (hearing inotion to strike brought by FSLIC, receiver). In Fields, the receiver did object that the claimant had failed to "file" the claim with the receiver, but the court appears to have aecepted that this had been done orally and that the claim had been rejected orally. $128 \mathrm{~F} .2 \mathrm{~d}$ at 706-07. In any event, the court then proceeded to adjudicate the merits of the claim itself.

388. Ch. $649, \S \S 501,503,68$ Stat. 590, 633-37 (codified as amended at 12 U.S.C. $\S \S 1725,1464$ (1982)).

389. Id. $\S 501(2), 68$ Stat. at 633 (codified as amended at 12 U.S.C. $\S 1728$ (1982)) (adding $\S 405$ (c) to the National Housing Act).

390. The FSLIC's attempt to extend the Hudspeth doctrine to claims involving insured deposits by arguing that the claimant is entitled not to review de novo, but ouly to APA-type review, was rejected in Jugum v. FSLIC, 637 F. Supp. 1045, 1046-48 (W.D. Wash. 1986). The Jugum decision las now been vacated as moot. Telephone interview with David A. Felt, Assistant General Counsel, FHLBB (Apr. 28, 1988); cf. Herbert v. NCUAB, 663 F. Supp. 833, $839-44$ (E.D. Mo. 1987) (NCUAB decisions pursuant to 12 U.S.C. § 1687(c)(1) are not subject only to arbitrariness review under the APA) (discussed infra in text accompanying notes 468-72).

On the other land, the FSLIC has successfully secured the application of the Hudspeth doctrine in other cases involving insured depositors' claims. See, e.g., York Bank \& Trust Co. v. FSLIC, 663 F. Supp. 1100 (M.D. Pa. 1987) (holding that any claim arising from the FSLIC's power as a receiver is limited to remedies provided under the APA), vacated on other grounds, 851 F.2d 637 (3d Cir. 1988) (court divided 2 to 1 on this issue); Baskes v. FSLIC, 649 F. Supp. 1358, 1365 (N.D. Ill. 1986) (claim of negligenee brought against FSLIC dismissed because administrative remedies not exhausted); cf. Wyatt v. FSLIC, 685 F. Supp. 196, 198 (E.D. Ark. 1988); Berz v. FSLIC, No. CA3-870681-R, slip op. at 4 (N.D. Tex. Feb. 15, 1988) (APA-type review applied in granting summary judgment to FSLIC on its determination of validity of insured depositors' claims).

391. This was one of the provisions of the National Housing Act that convinced the Ninth Circuit in Morrison-Knudsen that the judicial determination of other creditor claims could not have been precluded. See Morrison-Knudsen Co. v. CHG Int'l, Inc., 811 F.2d 1209, 1220 (9th Cir. 1987), 
The Act also made provision for the FHLBB to secure enforcement orders, administratively and judicially, against delinquent thrifts as an alternative to placing them in conservatorship or receivership. ${ }^{392}$ It enunciated specific grounds for, and required formal administrative hearings in the case of, the appoimtment of conservators, receivers and supervisory representatives. ${ }^{393}$ It is worth noting that here, where Congress specifically addressed the question of administrative adjudication, it prescribed detailed procedures and primciples upon which decisions should be based.

e. Introduction of section $1464(d)(6)(C)$. In 1966, after the FHLBB had been experiencing difficulty in securing the cooperation of the managers of some dehinquent thrifts, ${ }^{394}$ Congress, in the Fimancial Institutions Supervisory Act of 1966,395 granted the FHLBB power to issue and seek enforcement of cease and desist orders, as an alternative to the FHLBB's power to place thrifts in receivership and as an alternative to the FSLIC's power to terminate the insurance of a delinquent institution, both actions being considered sometimes too drastic. ${ }^{396}$ Most importantly, the Act also inserted for the first time subsection 1464(d)(6)(C), which forbids the courts from "restrain[img] or affect[img] the exercise of powers ... of a . . . receiver," except at the instance of the Board. ${ }^{397}$ Subsection 1464(d)(6)(C) is one of the bases upon which the agencies assert exclusive claims adjudicatory power.

This preclusion of court jurisdiction is ambiguous. It was formulated within the context of a provision that is primarily concerned with the appointment and removal of, and not the discharge of functions by, conservators and receivers. Subsection (8) of the insertion made provision for court apphications by the FHLBB, "in its discretion," for the enforcement of notices issued by it under its extended powers, mcluding not only the issue of cease and desist orders but also the appointment and

petition for cert. fled sub nom. FSLIC v. Stevenson Assocs., 56 U.S.L.W. 3249 (U.S. Sept. 17, 1987) (No. 87-451).

392. Housing Act, ch. $649, \S 503(2), 68$ Stat. at $634-36$ (codified as amended at 12 U.S.C. $\S 1464$ (1982)) (amending $\$ 5(d)$ of Home Owners' Loan Act of 1933).

393. Id. $\S 503(2), 68$ Stat. at 635-36 (codified as amended at 12 U.S.C. $\S 1464$ ).

394. See, e.g., S. REP. No. 1482, 89th Cong., 2d Sess. 5-6, reprinted in 1966 U.S. CoDE CoNG. \& AdMIN. News 3532, 3537-38; House COMM. ON BANKING \& CURRENCY, 89TH CoNG., 2D SESS., FinANCIAL INSTITUTIONS SUPERVISORY AND INSURANCE ACT, HEARINGS ON H.R. 17899, at 33, 37 (Comm. Print 1966) (stateinent of John E. Horne, Chairman, FHLBB) [hereinafter Statement of John E. Horne]).

395. Pub. L. No. 89-695, 80 Stat. 1028 (codified as amended at 12 U.S.C. $\S 1464$ (d)).

396. See, e.g., Statement of John E. Horne, supra note 394, at 36.

397. Financial Institutions Supervisory Act, Pub. L. No. 89-695, $\S 6(\mathrm{C}), 80$ Stat. at 1033 (codified as amended at 12 U.S.C. $\$ 1464(d)(6)(C))$. 
removal of receivers. ${ }^{398}$ This would suggest that Congress was concerned, not with details such as the determination of valid creditor claims, but with the creation, responsibility, and termination of receiverships, and the need to subject these concerns to the authority of the FHLBB. What Congress appeared to have in mind in precluding courts from "restraining" or "affecting" receiverships was the possibility that a FHLBB-appointed receiver might be harassed in the exercise of its wideranging discretionary powers by mjunctions issuing from state courts at the instance, for example, of aggrieved ex-directors. Viewed from this perspective, subsection 1464(d)(6)(C) seems hittle more than a strengtheuing and codification of the principle of deference toward discretionary receivership powers that had long before been developed by state and federal courts in relation to statutory financial receiverships, ${ }^{399}$ and the provision does not necessarily imply that the validity of the credit obligations that the receiver is bound to pay should not, when in dispute, be settled in court. 400

Furthermore, wherever Congress expressly addressed the subject of adjudication, it again made provision for the conduct of hearings ${ }^{401}$ and provided for judicial review under the APA. ${ }^{402}$ If administrative claims adjudication and exclusion of the courts had been contemplated, one might expect Congress to have been more exphicit in expresing such intent: after all, the Chairman of the FDIC had specifically stated when describing the purpose and contents of the House bill that "[t]here are

398. Id., § 101(a), 80 Stat. at 1028 (codified at 12 U.S.C. $\$ 1464(d)(8)$ ) (adding new $\S 5(d)(8)$ to Home Owners' Loan Act). The provision of this facility does indicate how much responsibility Congress has been prepared to entrust to the FHLBB: few other agencies have authority to prosecute enforcement actions without the participation of an independent prosecutorial agent. See Diver, A Theory of Regulatory Enforcement, 28 PUB. PoL'y 257, 287 (1980).

399. See supra text accompanying notes 347-53.

400. Cf. Statement of John E. Horne, supra note 394, at 38 ("As a natter of fact, there can be no doubt that the approach of this bill markedly imcreases the role of judicial review in the process of supervision of financial institutions. At the same time, the Board beheves it essential for the supervisory agency that examines and is familiar with the developments in a financial institution to be able to judge when action is necessary and what action is appropriate, and to act promptly if the matter is urgent."). If exclusive claims adjudicatory power had been sought by the Board, one would expect the General Counsel, whose office actually drafted the bill, to have requested it. There is no mention of the subjeet in the General Counsel's statement.

401. See Financial Institutions Supervisory Act of 1966, Pub. L. No. 89-695, §§ 101(a), 102, 80 Stat. 1028, 1028, 1036 (inserting $\S 5(\mathrm{~d})(7)$ into the Home Owners' Loan Act, 12 U.S.C. $\S 1464(d)(7)$ (1982), and amending $\S 407$ of the National Housing Act, 12 U.S.C. $\S 1730(j)(2)$ (1982)).

402. See S. ReP. No. 1482, supra note 394, at 15, 25, reprinted in 1966 U.S. CodE CoNG. \& ADMIN. NEwS at 3546, 3557 (section-by-section analysis). The House bill, H.R. 17899, provided for judicial review according to the "weight of the evidence" standard. See H.R. REP. No. 2077, 89th Cong., $2 \mathrm{~d}$ Sess. 6 (1966) (the standard of review should be a "weight of the evidence" rather than "substantial evidence" standard). But the Senate bill, S. 3158, was passed in heu of the House bill and the inodification was dropped. See also infra text accompanying note 504. 
carefully drawn provisions with respect to administrative hearings and judicial review which fully protect the rights of individuals and insured institutions against whoin action inay be taken by the supervisory agencies." 403

f. Introduction of section 1464(d)(11). On the other hand, the 1966 Act added more detail to the general power of the FHLBB to regulate the conduct of receiverships. It introduced the predecessor to the present section 1464(d)(11), ${ }^{404}$ which is expressed in very broad terms. ${ }^{405}$ The legislative history provides no indication as to the intention of Congress with regard to this provision, ${ }^{406}$ so it is quite plausible that the legislative intention was for the FHLBB to deal with claims adjudication as a matter of administrative detail and agency expertise.

g. Extension of receivership appointment powers. The Bank Protection Act of $1968^{407}$ extended the powers of the FHLBB to appoint the FSLIC as receiver of insolvent state thrifts. This was effected against a background of obstruction on the part of the Illinois authorities, who had refused to appoint the FSLIIC as receiver in four cases even though the FSLIC was the insurer of deposits in those thrifts and by far the major creditor. ${ }^{408}$ The state authorities had for a number of inonths denied the FSLIC access to information concerning the thrifts; during this time their financial condition deteriorated rapidly, to the ultimate cost of the Insurance Fund. 409 Congress was concerned that the FHLBB and the FSLIC should be able to act quickly in such cases, ${ }^{410}$ so it extended the former's powers to appoint the FSLIC as receiver, and extended the operation of section 1464(d)(6)(C) to FSLIC receiverships involving state-

403. House COMm. ON BANKing \& CURRENCY, 89TH CONG., 2D SESS., supra note 394, at 27 (statement of K.A. Randall, Chairman, FDIC).

404. Fimancial Institutions Supervisory Act, Pub. L. No. 89-695, $\S 101$ (a), 80 Stat. at 1028 (inserting § 5(d)(11) in the Hoine Owners' Loan Act, 12 U.S.C. § 1464(d)(11) (1982)).

405. 12 U.S.C. § 1464(d)(11); see also supra text accompanying note 187.

406. See S. REP. No. 1482, supra note 394, at 15, reprinted in 1966 U.S. CODE CONG. \& ADMiN. News at 3546.

407. Pub. L. No. $90-389,82$ Stat. 294 (codified as amended at 12 U.S.C. $\S \S 1729,1881-1884$ (1982)).

408. See S. REP. No. 1263, 90th Cong., 2d Sess. 6-7, reprinted in 1968 U.S. CODE CONG. \& ADMIN. News 2530, 2536-37. The FSLIC was estimated to have a claim to at least $95 \%$ of the receivership assets, see id. at 2, 7, reprinted in 1968 U.S. CoDe Cong. \& ADMIN. News at 2531, 2536, which again indicates how low a priority was given the concern for determination of other creditor claims.

409. See id., reprinted in 1968 U.S. Code Cong. \& AdmiN. News at 2531, 2536.

410. The Fifth Circuit in Hudspeth placed great einphasis on this concern, see Hudspeth, supra note 103, 756 F.2d at 1101, 1102, but did not explain the context in which the FHLBB and FSLIC powers were being cxtended to state thrifts. 
chartered thrifts.411 Given the fact that the claims of creditors other than the FSLIC amounted to less than $5 \%,{ }^{412}$ it is hardly likely that the claims determination process was within the contemplation of Congress.

The Garn-St Germain Depository Institutions Act of $1982^{413}$ granted the FHLBB the emergency power exclusively to appoint the FSLIC as receiver for state-chartered thrifts in situations where the cooperation of state authorities had formerly been required, and it recodified the discretionary powers enjoyed by the FSLIC as receiver. ${ }^{414}$

h. Modification of section 1729(d). Subsection 1729(d) was also temporarily modified by the 1982 Act to make clear the FHLBB's exclusive regulatory authority over the FSLIC as receiver of state thrifts. ${ }^{415}$ The basic power to "settle, compromise, or release" claims, and to "do all other things as may be necessary in connection therewith" remained unaffected; the intention was that the receivership powers of the FSLIC over state thrifts should be "approximately equal to those which it now has with respect to Federal Associations." 416

Fimally, the Competitive Equality Banking Act of $1987^{417}$ made the emergency provisions of the Garn-St Germain Act, including the thensunsetted amendments to section 1729 (d), ${ }^{418}$ permanent by deleting the

411. See Bank Protection Act, Pub. L. No. 90-389, § 6, 82 Stat. at 295 (modifying $\S 406$ of the National Housing Act, 12 U.S.C. $\S 1729$ (1982), and § 5(d) of the Home Owners' Loan Act, 12 U.S.C. § 1464(d) (1982)). The Senate Report described $\S 1464(d)(G)(C)$ as preventing the "appointment of the FSLIC as receiver by the Board" from being "subject to judicial attack." See S. REP. No. 1263, supra note 408, at 10, reprinted in 1968 U.S. CoDE CONG. \& ADMIN. NEwS at 2539. The Report then einphasized that the Board's regulatory authority was to be substituted for that "of any State authority, administrative or judicial, which may previously have had regulatory authority," $i d$. and concluded that "[t]he effect of the legislation would be to enable the FSLIC to defend its appointment under Federal law instead of requiring it to defend the legality of the State savings and loan administrator's determinations under State law," id. at 11, reprinted in 1968 U.S. CODE CoNG. \& ADMIN. NEwS at 2540 . Claims adjudication seems not to have been contemplated.

412. See supra note 408.

413. Pub. L. No. 97-320, 96 Stat. 1469 (codified as amended in scattered sections of 11 U.S.C., 12 U.S.C., 15 U.S.C. and 20 U.S.C.).

414. Garn-St Germain Depository Institutions Act § 122(b), 12 U.S.C. § 1729(f) (1982).

415. Id. $\$ 122(\mathrm{~g}), 12$ U.S.C. $\$ 1729$ (d) (1982); see supra text accompanying note 186 (quoting the temporary (and now permanent) wording in full); see also infra text accompanying notes 417-19.

416. S. REP. No. 536, 97th Cong., 2d Sess. 48, reprinted in 1982 U.S. CODE CONG. \& ADMiN. NEws 3054, 3102. It is significant that Congress emphasized that the Insurance Fund would not be liable for the noninsured claims of creditors. See id. at 49, reprinted in 1982 U.S. CoDE. Cong. \& ADMN. NEws at 3103. This probably reflects awareness of the growing diversification of thrift busmess and the increasing importance of noninsured creditor claims. It also suggests that it is only at this point that legislators could have begun to address seriously the detail of creditor claims adjudication.

417. Pub. L. No. $100-86,101$ Stat. 552 (to be codified in scattered sections of 12 U.S.C.A.).

418. See supra text accompanying note 186 (quoting the final version of $\S 1729(d)$ in full). 
sunset clauses in the 1982 Act. $^{419}$

This review highlights the ambiguity surrounding the receivership claims determination power. It is very unlikely that Congress at any stage directly addressed the inatter, and neither section 1464(d)(6)(C) nor section 1729 (d) can seriously be regarded as direct authority for exclusive administrative adjudication. The court in Summertree Venture III v. Federal Savings \& Loan Insurance Corp. ${ }^{420}$ was surely correct in concluding:

The reasons the FSLIC can be appointed, the timing of the appointment, and the entity that is authorized to make the appointment have changed throughout the years, but the powers and functions of the receiver in connection with the hquidation have not been expanded since the original acts. ${ }^{421}$

i. The irrelevance of sections $1464(d)(6)(C)$ and 1729(d). Not only do sections $1464(d)(6)(C)$ and 1729(d) provide a very dubious basis for the adjudicatory powers claimed by the FHLBB and the FSLIC, but rehance upon them also involves the agencies in self-contradiction, smce, ultimately, section 1464(d)(G)(C) proves too much and section 1729(d) proves too little.

If section $1464(d)(6)(C)$ really does preclude the jurisdiction of the courts in matters relating to claims determination, then, contrary to the FSLIC's own arguments and the Hudspeth decision itself, 422 judicial review "under the APA"423 would not be available at all because the APA expressly denies judicial review where the applicable statute precludes it. ${ }^{424}$ Hence, to be consistent, the FSLIC should have argued, and the Fifth Circuit in Hudspeth should have held, that judicial review is demed altogether. ${ }^{425}$

On the other hand, section 1729(d) confers power on the receiver (i.e., the FSLIC), not the FHLBB. If the power to adjudicate lies therein, then the FHLBB, in creatimg a structure in which adjudication really takes place only at the level of the Adjudication Division of the

419. Pub. L. No. 100-96, §509(a), 101 Stat. at 635.

420. 742 S.W.2d 446 (Tex. Ct. App. 1987).

421. Id. at 453.

422. See Hudspeth, supra note 103, 756 F.2d at 1103.

423. Id.

424. 5 U.S.C. $\$ 701($ a)(1) (1982).

425. This rule has some judicial qualifications, designed to avoid due process difficulties. See, eg., Johnson v. Robison, 415 U.S. 361, 372-73 (1974) (the no-review clanse of laws administered by the Veterans' Admimistration, 38 U.S.C. $\$ 211$ (a) (1982), was designed to proscribe courts from making benefit determinations, not to proscribe judicial cognizance of constitutional challenges to veterans' benefits legislation). But these are exceptions, and it would be misleading to assume that their effect is simply to reinstate "judicial review under the APA." 
Office of General Counsel of the Board, ${ }^{426}$ has to that extent usurped a power conferred on the receiver. In other words, the FHLBB cannot, in claiming adjudicatory power for itself, rely on power conferred upon another agency, even if that agency is subject to its direction.

j. Section 1464(d)(11) as the best basis for the Hudspeth scheme. Yet it does not necessarily follow that there can be no administrative adjudication. Such a conclusion would ignore the broad power conferred on the FHLBB by section 1464(d)(11), which, under Chevron, would ordinarily create a strong presumption in favor of the Board's interpretation of the section. ${ }^{427}$ The Supreme Court has determined in certain contexts that "receivership" powers do not entail a clanns adjudication power, 428 but the receivership concept has been used in such widely varying contexts, and the thrift industry has been subjected to autonomous regulation for so long, that it would be an exercise in sterile conceptualism to conclude that claims adjudication is inherently precluded by the notion of receivership.

If the obfuscation of sections $1464(d)(6)(C)$ and $1729(d)$ is avoided, and constitutional concerns are left aside, the claim that the FHLBB, in the exercise of its general regulatory powers under section 1464(d)(11), can establish a claims adjudication scheme becomes much more plausible. A court could conclude that since Congress has not directly addressed the issue, as it plainly lias not, the conclusion by the Board that it is empowered to establish a claims adjudication sclieme is a "permissible" construction of its powers and therefore one that the court should accept. 429

3. FDIC and NCUAB Analogues. Before leaving the question of statutory power it is helpful briefly to review two possible analogies, one of which might suggest that claims adjudication is not within the range of FHLBB and FSLIC powers, and the other of which tends to support the FHLBB's and FSLIC's claim. The first involves the FDIC, and the second the NCUAB.

a. The FDIC. The practice of the FDIC may be of assistance for a variety of reasons. First, the FSLIC insurance scheme was at least

426. See supra text accompanying note 250 .

427. See supra text accompanying notes 325-36.

428. See supra text accompanying notes 108-09.

429. See supra text accompanying notes 326-27 (discussing the sccond stage of the Chevron analysis). In Commodity Futures Trading Comm'n v. Schor, 478 U.S. 833, $841-43$ (1986), see infra text accompanying notes $576-88$, the Court held that the CFTC had the power to create a reparations jurisdiction by rule, though there the statute seemed, in view of its direct reference to "reparation orders," more clearly to contemplate that the agency would do so. 
partly modeled on that of the FDIC,430 and the techniques employed by the FSLIC to assist troubled thrifts are very similar to those employed by the FDIC. ${ }^{431}$ Second, Congress has often amended and extended the receivership powers of the FSLIC and the FDIC in the same legislation..$^{432}$ Third, the activities of banks and thrifts are becoming increasingly similar. ${ }^{433}$ The overlap is highlighted by the fact that the FDIC is appointed by, and subject to the authority of, the FHLBB when it acts as receiver for a failed federal savings bank. ${ }^{434}$ The FDIC has indeed adopted the view that the Hudspeth doctrine applies to the determination of creditor claims when it is hquidating such banks. ${ }^{435}$ Fourth, the FDIC has had longer experience in dealing with the claims of non-insured depositors ${ }^{436}$ and faces similar problems regarding the escalation of failed banks and the depletion of its imsurance fund.437 Finally, some judicial decisions, while fully acknowledging the controlling force of Chevron, have directly drawn on the analogies between the two agencies in rejecting the FHLBB's and FSLIC's interpretations of their statutory mandates. ${ }^{438}$

The FDIC must be appointed receiver of failed federal savings banks, $m$ which case appomtments are made by the FHLBB, and of failed national banks, in which case appointments are made by the Comptroller of the Currency. ${ }^{439}$ The FDIC may also accept appointment as receiver of an imsured state bank if such appointinent is tendered

430. See supra text accompanying notes $384-85$.

431. See supra note 182.

432. See, e.g., Competitive Equality Banking Act of 1987, Pub. L. No. 100-86, § 714(a), 101 Stat. 552, 654 (codified at 12 U.S.C.A. § 1787(a)(1)(B) (West Supp. 1988); Garn-St Germain Depository Institutions Act of 1982, Pub. L. No. 97-320, 96 Stat. 1469 (codified in scattered sections of 12 U.S.C.); Bank Protection Act of 1968, Pub. L. No. 90-389, 82 Stat. 294 (codified at 12 U.S.C. $\S \S 1729,1881-1884$ (1982)); see also supra notes 407-19.

433. See supra text accompanying notes 53-57.

434. See supra text accompanying notes $167-68$.

435. See supra note 181.

436. See Morrison-Knudsen Co. v. CHG Int'l, Inc., 811 F.2d 1209, 1221 (9th Cir. 1987), petition for cert. filed sub nom. FSLIC v. Stevenson Assocs., 56 U.S.L.W. 3249 (U.S. Sept. 17, 1987) (No. 87451).

437. See, e.g., Nash, FDIC Faces a Texas-Size Drain, N.Y. Times, Mar. 17, 1988, at D1, col. 3 , D6, col. 4 (city ed.).

438. See, e.g., Morrison-Knudsen, 811 F.2d at 1221 (the FDIC's practice of litigating disputed claims in court supports the conclusion that the FSLIC did not have adjudicatory power); $c f$. FAIC Sec., Inc. v. United States, 768 F.2d 352, 361-64 (D.C. Cir. 1985) (Scalia, J.) (applying Cherron analysis and relying upon the "clarity of congressional intent expressed with regard to the FDIA" in determining whether an inconsistent interpretation by the FHLBB of the "far from clear" National Housing Act was a "permissible" one; concluding that it was not). Although FAIC involved the definition of insured accounts, it is still relevant: the FDIC analogy was held to be guiding even at the second stage of the Chevron analysis.

439. 12 U.S.C. $\S 1821$ (c) (1982). On the rare case of federal savings bank receiverships, see supra text accompanying notes 167-69. For the grounds for appointing the FDIC as receiver of a national bank, see 12 U.S.C. $\S 191$ (1982). 
by the relevant state authority. 440

Upon appointinent, the FDIC is required to pay insured deposits, either by cash or by means of transferred accounts. ${ }^{441}$ With respect to insured national banks, the FDIC has a wide range of powers to provide financial assistance to insured banks in order to avoid receivership, and, upon receivership, may create new banks and "bridge banks" for the purpose of impleinenting purchase and assumption transactions. ${ }^{443}$

Here the similarities with the FSLIC end. In particular, the hquidation practice of the FDIC is very different: the FDIC, unlike the FSLIC, does not assert the power to adjudicate the validity of creditor claims, whether they be those of insured depositors or uninsured and general creditors. The FDIC reties instead upon the courts to resolve these claims. ${ }^{444}$ As a result, the FDIC inakes informal, ad hoc arrangements in the case of each receivership; 445 it lacks guidelines similar to those that have been created by the FHLBB for thrift receiverships. ${ }^{446}$

The practice of the FDIC might therefore suggest that the assumption of adjudicatory authority by the FHLBB and the FSLIC is unjustified. But there are a nuinber of important differences in the regulatory and statutory contexts of each agency that might justify the difference.

First, while the FDIC, when acting as reviewer of a federal savings bank, stands in the same relationship to the FHLBB as does the FSLIC when acting as receiver of a thrift, the FDIC is no longer subject to the Coinptroller's regulatory authority when it is appointed by the Comptroller to act as a receiver for a closed national bank. ${ }^{447}$ Hence the appellate structure created by the FHLBB under the Hudspeth doctrine is not available to the FDIC, except in the case of receiverships involving savings banks. The conflict of interest that would be involved were the FDIC to adjudicate claims in its receiverships is therefore even more intense because of the absence of institutional separation.

Second, whereas the FHLBB has long been given exclusive regulatory authority over the FSLIC's receiverships even in the case of federally insured state thrifts, the "rights, powers and privileges" of the FDIC

440. 12 U.S.C. $\$ 1821(\mathrm{e})$.

441. 12 U.S.C. $\$ 1821(\mathrm{f})$.

442. See 12 U.S.C. $\$ 1823(\mathrm{c})$ (1982).

443. See 12 U.S.C.A. § 1821(h)-(i) (West Supp. 1988); see also supra note 182.

444. By July 1987, the FDIC was involved in approximately 27,000 lawsuits involving claims against its receiverships. Interview with Carroll Shifett, Assistant General Counsel, FDIC, in Washington, D.C. (July 21, 1987).

445. Interview with Roger Hood, Assistant General Counsel, FDIC, in Washington, D.C. (Oct. 22, 1987).

446. See supra text accompanying notes 201-05.

447. 12 U.S.C \& $1821(d)$. 
as receiver are entirely governed by the relevant provisions of state law when it is appointed receiver of a state bank. ${ }^{448}$ This means that the FDIC would have to abide by the claims adjudication provisions or practices of state law. Thrift receiverships stand in contrast: once under the regulatory authority of the FHLBB, the FSLIC as receiver of a state thrift is restricted only by the proviso to the jurisdictional provisions of 12 U.S.C. section $1730(\mathrm{k})(1) .449$ The section vests jurisdiction over suits involving the FSLIC in the federal district courts, and it makes federal law controlling. But it stipulates in its proviso

[t]hat any action, suit, or proceeding to which the [FSLIC] is a party in its capacity as ... receiver ... of an insured State-chartered institution and which involves only the rights or obligations of investors, creditors, stockholders, and such institution under State law shall not be deened to arise under the laws of the Urited States. ${ }^{450}$

Although it has been suggested that the proviso supports the argument against claims adjudicatory powers because it indicates a "tacit assumption" on the part of Congress that such claims would be amenable to judicial resolution, ${ }^{451}$ the proviso addresses not the powers of the FSLIC or the FHLBB, but only the law governing the criteria by which claims should be resolved. ${ }^{452}$

The guidance provided by practice at the FDIC is therefore inconclusive. At inost it casts doubt upon the plausibility of the FHLBB's assuinption of powers, but, especially when one considers the jurisdictional differences between the FDIC on the one hand, and the FHLBB and the FSLIC on the other, the FDIC's general practice of litigating disputed claims in court is insufficient in itself to render the FHLBB's interpretation of its powers "inpermissible." 453

448. 12 U.S.C. $\$ 1821(\mathrm{e})$.

449. See 12 U.S.C. $\S 1730(k)(1)(1982)$.

450. $\mathrm{Id}$.

451. See Morrison-Knudsen Co. v. CHG Int'l, Inc., 811 F.2d 1209, 1220-21 (9th Cir. 1987), petition for cert. filed sub nom. FSLIC v. Stevenson Assocs., 56 U.S.L.W. 3249 (U.S. Sept. 17, 1987) (No. 87-451).

452. Section $1730(\mathrm{k})(\mathrm{l})$ is really analogous to the fourth power established in 12 U.S.C. $\S 1819$ (1982), which prescribes the governing law and jurisdiction in disputes involving the FDIC. Cf. In re FSLIC, 837 F.2d 432, 435-36 (11th Cir. 1988) (citing section 1819 cases in support of section $1730(k)(1)$ issue); FSLIC v. Ticktin, 832 F.2d 1438, 1444 (7th Cir. 1987) (relying heavily on section 1819 caselaw in deciding $\S 1730(\mathrm{k})(1)$ issue), petition for cert. filed, 56 U.S.L.W. 3834 (U.S. May 12, 1988) (No. 87-1865); Polk v. FDIC, No. 87-C-9433 (N.D. Il. Mar. 1, 1988) (Westlaw, 1988 wL 19575) (cases involving FDIC removal and FSLIC removal can be cited interchangeably). But see FSLIC v. T.G. Partners, Ltd., 689 F. Supp. 683 (N.D. Tex. 1988) (stressing differences between section 1819 and section $1730(\mathrm{k})(1))$.

453. The FAIC case, see supra note 438, can be distinguished in that it involved an interpretation of depositors' substantive rights and not the means by which disputes concerning those rights should be resolved-a concern that, in the absence of constitutional constraints and explicit legislative gui- 
b. The NCUAB. The receivership powers of the NCUAB are something of a hybrid. The NCUAB is empowered to place federal credit unions into liquidation and appoint itself the "liquidating agent." 454 It is also authorized to accept appointment as liquidating agent of an insured state-cliartered credit union. ${ }^{455}$ As in the case of the FDIC, in such situations it possesses the "rights, powers, and privileges" granted by the applicable state law. ${ }^{456}$ The NCUAB, in section 1788(c), also enjoyed receivership powers that were framed, before the enactment of the Competitive Equality Banking Act of 1987,457 in terms identical to those possessed by the FSLIC under section 1729(d) before the latter provision was amended in 1982.458 In addition, the NCUAB, like the FDIC and the FSLIC, niust pay insurance to insured depositors when a credit union is closed for liquidation and, like the FDIC and the FSLIC, can require claimants to insurance to prove the validity of their claims in court. 459

Unlike the legislation governing thrift liquidations, however, the powers of an NCUAB liquidating agent were more explicitly articulated by the Act of July 31, 1946, which amended the Federal Credit Union Act. ${ }^{460}$ This legislation provides that a liquidating agent "shall have power and authority, subject to the control and supervision of the [NCUAB] and under such rules and regulations as the [NCUAB] may prescribe, ... to receive, examnie, and pass upon all claims against the Federal credit union in liquidation, including claims of members on member accounts."461 The Senate Report accompanying this amendment stated that " $[t]$ le provisions set out in this section . . . are similar to those which are customarily prescribed in other types of liquidations and would authorize, for exaniple, the apponitment of a liquidating agent, the receipt and adjudication of claims, and the distribution of dividends

dance, and in the presence of general regulatory authority (section 1464(d)(11)), might properly be regarded as the preserve of the agencies involved.

454. See 12 U.S.C.A. $\$ 1787(a)(1)(A)$ (West Supp. 1988).

455. See 12 U.S.C. $\$ 1787$ (b) (1982).

456. Id.

457. 12 U.S.C. $§ 1788(c)$ (1982) states:

In connection with the liquidation of any insured credit union, the Board shall have the power to carry on the business of and collect all obligations to the credit union, to settle, compromise, or release claims in favor of or against the credit umion, and to do all other things that may be necessary in connection therewith, subject to the regulation of the court or other public body having jurisdiction over the matter.

458. On the 1982 FSLIC amendment, see supra text accompanying notes 415-19.

459. See 12 U.S.C. $\$ 1787$ (c)(1).

460. Ch. $711, \S 8,60$ Stat. 744,745 (codified at 12 U.S.C. $\S 1766($ b)(3) (1982)).

461. 12 U.S.C. $\$ 1766(\mathrm{~b})(3)(B)$ (1982). 
thereon." 462

The 1946 legislation and the accompanying Senate Report were considered by the court in Morrison-Knudsen in its review of the practices and legislation pertaining to the liquidation practices of otler regulatory agencies. ${ }^{463}$ The panel concluded, lowever, that even if Congress liad really intended to suggest that the other agencies had exclusive claims adjudicatory power (which is not at all clear from the wording used in the Report), then Congress "was mistaken."464 In any event, the court concluded, the NCUAB legislation and history was "so remote from the cases at bar that it cannot affect our decision." $" 465$

The Morrison-Knudsen court was surely correct to doubt that Congress intended to vest the liquidating agent with an exclusive adjudicatory power. The 1946 amendment liad also inserted a provision that expressly recognized that claims miglit be established througli the judicial process. ${ }^{466}$ The formulation employed was similar to that used in legislation governing the receivership of national banks prior to the creation of the FDIC, with respect to which there had been no doubt that creditors could resort to court to establisli their claims. ${ }^{467}$ It is therefore most unlikely that Congress imtended that liquidating agents slould liave exclusive power to adjudicate claims to the preclusion of the courts.

Soon after Morrison-Knudsen, in Herbert v. National Credit Union Administration Board, ${ }^{468}$ the exclusivity of the NCUAB's claims adjudicatory powers again became the subject of judicial scrutiny, this time within the context of determinations mvolving the validity of deposit insurance claims. The NCUAB argued that its determinations could not be challenged in court de novo, but were subject only to APA judicial review. In support of its argument the NCUAB invoked two cases that had expressly relied upon Hudspeth. ${ }^{469}$ In effect, the NCUAB argued for

462. S. REP. No. 1647, 79th Cong., 2d Sess. 2, reprinted in 1946 U.S. CODE CONG. SERv. 1323, 1324 (emphasis added).

463. See Morrison-Knudsen Co. v. CHG Int'l, Inc., 811 F.2d 1209, 1219 n.3 (9th Cir. 1987), petition for cert. filed sub nom. FSLIC v. Stevenson Assocs., 56 U.S.L.W. 3249 (U.S. Sept. 17, 1987) (No. 87-451).

464. Id.

465. Id.

466. Section 1766(b)(4)(B), which was inserted by the 1946 Act, provides that the liquidating agent shall "Inake a ratable dividend on all such claims as may lave been proved to his satisfaction or adjudicated in a court of competent jurisdiction." 12 U.S.C. $\S 1766(\mathrm{~b})(4)(B)$ (1982) (emphasis added).

467. See, e.g., Schulenberg v. Norton, 49 F.2d 578, 580 (8th Cir. 1931) (applicable legislation required receiver to pay claims proven to his satisfaction or adjudicated in court of competent jurisdiction); see also supra text accoinpanying note 352 .

468. 663 F. Supp. 833 (E.D. Mo. 1987).

469. Godwin v. FSLIC, 806 F.2d 1290 (5th Cir. 1987); Baskes v. FSLIC, 649 F. Supp. 1358 (N.D. Ill. 1986). 
an extension of the Hudspeth doctrine (concerning exclusive administrative claims adjudication) to the determination, in federal credit union hiquidations, of the claims of insured depositors.

Findimg no guidance in the relevant legislative history, and noting the provision of elaborate procedural prescriptions elsewhere in the Credit Union Act ${ }^{470}$ and the absence of detailed administrative rules like those proinulgated by the FHLBB, 471 the court rejected the NCUAB's arguinent. Chief Judge Nangle was unimpressed by the references to Hudspeth, which, he noted, "[did] not in any way nivolve an FSLIC insurance claim." 472

The decision in Herbert and the reference in Morrison-Knudsen to the NCUAB's powers assune some significance in view of subsequent legislation passed by Congress. Morrison-Knudsen was decided on February 25, 1987, and Herbert was decided on June 29, 1987. The Competitive Equality Banking Act, which amended the NCUAB's powers, was enacted on August 10,1987. The Act modified the NCUAB's receivership powers in two ways. First, it added a new subsection to the receivership appointment power, ${ }^{473}$ providing for judicial challenge to the closure of a credit union, and adding a provision that serves as an analogue to section 1464(d)(6)(C). ${ }^{474}$ Second, the 1987 Act transferred section 1788(c) (the NCUAB's equivalent of section 1729(d)) to section 1787, and amended it in terms identical to those that were used to amend section 1729(d) by the Garn-St Germam Act of 1982.475

Congress had thus directly addressed one aspect of the receivership powers of the NCUAB, so the legislative history has particular significance. And in the Senate Report we find, tailor-made for the adoption of the Hudspeth doctrime, the following statement:

The Committee expects that hquidations conducted under this section shall be accomplished as expeditiously as possible in order to achieve minimal disruption to the financial system. Creditor, member and other claimants must be dealt with in a fair maimer. These amend-

470. See Herbert, 663 F. Supp. at $839-40$.

471. Id. at 842 .

472. Id. (rejecting suggestions to the contrary in Godwin, $806 \mathrm{~F} .2 \mathrm{~d}$ at $1292 \mathrm{n} .4$ ).

473. Competitive Equality Banking Act, Pub. L. No. 100-86, § 714(a), 101 Stat. at 654 (codified at 12 U.S.C.A. $\S 1787(a)(1)(B)$ (West Supp. 1988)).

474. "Except as otherwise provided in this subparagraph, no court may take any action for or toward the removal of any hiquidating agent or, except at the instance of the Board, restrain or affect the exercise of powers or functions of a liquidating agent." $I d$.

475. Id. § 714(b), 101 Stat. at 655 (codified at 12 U.S.C.A. § 1787(j) (West Supp. 1988)) (imserting the words "subject only to the regulation of the Board, or, in cases where the Board has becn appointed hquidating agent solely by a public authority having jurisdiction over the matter other than the said Board, subject only to the regulation of such public autlority"). On the Garn-St Germain ainendments, see supra notes $186,415-19$ and accompanying text. 
ments clarify the NCUA's authority to adjudicate liquidation claims.

Upon final agency action, a claimant may seek recourse in court under the provisions of the APA. ${ }^{476}$

While one should not place too much weight on legislative history, much of which is manufactured, ${ }^{477}$ the wordimg emphasized in the passage just quoted invites speculation as to the possible motives underlymg the amendments. Three possibilities suggest themselves.

First, the explicit reference to the APA as the statute governing the scope of judicial review could be taken as a renunciation of the law espoused in Herbert. This is an unlikely interpretation, however, simce the amendments left completely unchanged section 1787(c)(1), which expressly provides for the judicial resolution of disputed insurance claims, and upon which the court in Herbert exphicitly rehed. ${ }^{478}$

Second, the NCUAB could have been concerned that the dicta $\mathrm{m}$ the Morrison-Knudsen opinion had cast doubt upon what the NCUAB believes to be the exclusive power of hiquidating agents to adjudicate claims. The amendments may have been intended to clarify the situation. ${ }^{479}$ If such were the motivation, however, the NCUAB might not have been successful. The amendments address sections 1787 and 1788, and not section $1766(\mathrm{~b})(3)$. Yet it is the latter provision that appears to furnish the power to "adjudicate" claims and to which Morrison-Knudsen had referred. ${ }^{480}$ Not only do the amendments fail to address the actual subsection interpreted by Morrison-Knudsen (i.e., section $1766(b)(3))$, but it would also have been far simpler for Congress to have added an express provision to section $1777(b)(3)$ statimg that the power to adjudicate claims was exclusive, or subject only to APA review. It is also difficult to understand why the NCUAB drafters chose to adopt the very terminology 481 that had been in issue in Morrison-Knudsen in the FSLIC context, and which the court had interpreted so as to exclude the

476. S. ReP. No. 19, 100th Cong., 1st Sess. 25, reprinted in 1987 U.S. CODE CoNG. \& ADMIN. NEws 489, 515 (emphasis added).

477. Cf. Starr, Conference on Statutory Interpretation: The Role of Legislative History in Judicial Interpretation-Observations About the Use of Legislative History, 1987 DUKE L.J. 371, 376-77 (describing the "virtual cottage industry" engaged in fashioning legislative history "so that the Congress will appear to enbrace their partieular view in a given statute").

478. See 663 F. Supp. 833, 843 (E.D. Mo. 1987). Staff at the NCUAB assert that the Herbert decision was not the motive for obtaining the amendment. Telephone interview with Leslie A. Conover, Staff Attorney, FDIC (May 11, 1988). 478.

479. This is the explanation provided by staff at the NCUAB. Telephone interview,supra note

480. See supra text accompanying notes $460-65$.

481. The inodification of the terminology to coinport with the post-1982 wording of the FSLIC's section 1729(d) adds nothing of substance to the legislation. See supra notes 186, $415-16$ and accoinpanying text. 
power to adjudicate claims, ${ }^{482}$ was adopted. Instead, the amendments could simply have incorporated the exphicit terminology used in the Senate Report, thus avoiding the obscure and highly contentious verbiage of sections $1464(d)(6)(C)$ and 1729(d).

Given the similarity in wording and structure of the amended NCUAB provisions to those applicable to the FHLBB and FSLIC, a third possibility might be tliat the legislation and legislative history were unwisely framed under the influence of the cliaotic jurisprudence spawned by the Hudspeth decision. This would explain why the drafters chose to focus on the analogues to sections 1464(d)(6)(C) and 1729(d).

In any event, because tlie 1987 amendinents did address the NCUAB analogues to sections 1464(d)(6)(C) and 1729(d), and because the amendments reformulated the NCUAB provisions $\mathrm{m}$ terms that are virtually identical to pertinent parts of sections 1464(d)(6)(C) and 1729(d), the legislative history accompanying the amendments constitutes an endorsement of the contentions of tlie FHLBB and FSLIC. Yet the strength of this endorsement will depend on how seriously one should regard this legislative history and whether the reliance upon sections 1464(d)(6)(C) and 1729(d) as the sources of adjudicatory power has any merit at all. ${ }^{483}$

In conclusion, we can assume that, while it is doubtful that the FHLBB and the FSLIC enjoy exclusive claims adjudicatory autliority by virtue of the provisions of sections $1464(\mathrm{~d})(\mathrm{O})(\mathrm{C})$ and 1729(d), under section 1464(d)(11) the FHLBB could, in the absence of constitutional difficulties, ${ }^{484}$ enjoy authority, murky though it certainly would be, to establish an administrative claims adjudication sclieme. In order to complete the analysis of the legislative constraints, and before examining the constitutional constraints, we need to consider tlie suppleinentary apphcation of the APA.

4. Application of the APA. Given the wording of the FSLIC's statutory mandate, it is unlikely that any of the formal procedural requirements of the APA $^{485}$ apply to the receiver when these claims are

482. The court in Morrison-Knudsen thought that Congress's failure to speak more exphicitly in the 1982 amendments actually detracted from the force of the agencies' arguments. See MorrisonKnudsen Co. v. CHG Int'1, Inc., 811 F.2d 1209, 1221 (9th Cir. 1987), petition for cert. filed sub nom. FSLIC v. Stevenson Assocs., 56 U.S.L.W. 3249 (U.S. Sept. 17, 1987) (No. 87-451).

483. See supra text accompanying notes 422-26 (arguing that sections $1464(d)(6)(C)$ and $1729(d)$ are red herrings).

484. The principle of deference dictated by Chevron is balanced by the principle of strict construction when agency powers impinge upon coustitutional protections. See supra text accompanying notes 129-30.

485. 5 U.S.C. $\S \S 554-557$ (1982). 
being adjudicated. Hudspeth adjudications are likely to be construed as informal adjudications, and thus the only procedural requirements beyond those dictated by the FHLBB in its rules would be those dictated by constitutional due process. 486

As to judicial review, the courts applying Hudspeth have assumed that the standards articulated by the APA ${ }^{487}$ apply. The exact scope of review is probably governed by the "arbitrary and capricious" standard. 488

a. Adjudicatory procedure. Must the receiver follow the formal adjudicative procedures of the APA? These are triggered ouly in the case of "adjudication required by statute to be determined on the record after opportunity for an agency hearing, except to the extent that there is involved ... a matter subject to a subsequent trial of law and the facts de novo in a court."489 Assuming the FSLIC is correct in assertimg that creditors are not entitled to de novo judicial determination of the validity of their claims, we need to examine the statutory wording of the FSLIC's adjudicative authority in order to determine whether formal APA proceedings are triggered.

The FSLIC rehes on section 1729(d) for authority to adjudicate creditor claims. Subsection 1729(d) contains no obvious terminology to trigger the APA's requirements for formal adjudication. ${ }^{490}$ There is no provision for an "agency hearing," nor is there a requirement that the determination be made "on the record." The Supreme Court has insisted upon a literal or very clear triggering in the analogous case of formal rulemaking ${ }^{491}$ and, although it appears that the courts might be more willing to construe a requireinent of formal procedures in the case of adjudication, ${ }^{492}$ the complete absence in section 1729(d) of any reference to the form of procedure to be followed strongly suggests that formal proceedings are not contemplated; on the contrary, the words "settle, compromise, or release," and the preference for informal negotiation and

486. See infra notes $608-15$ and accompanying text.

487. 5 U.S.C. $\S 706$.

488. See id. $\S 706(2)(\mathrm{A})$.

489. Id. $\S 554(\mathrm{a})(1)$.

490. See supra text accompanying note 186 (quoting $\S 1729$ (d) in full).

491. See United States v. Florida East Coast Ry., 410 U.S. 224 (1973); Umited States v. Allegheny-Ludlum Steel Corp., 406 U.S. 742 (1972).

492. See Seacoast Anti-Pollution League v. Costle, 572 F.2d 872 (1st Cir.) (holding formal adjudication proceedings applicable under statute that did not contain words "on the record," but did require the decision to be made "after opportumity for public hearing"), cert. denied, 439 U.S. 824 (1978). But cf. Umited States Lines, Inc. v. Federal Maritime Comm'n, 584 F.2d 519, 536 (D.C. Cir. 1978) (holding that, in the absence of a requirement that a hearing be conducted "on the rccord," no formal adjudication was required by a statute that mandated "notice and hearing"). 
settlement on the part of thrift receivers, ${ }^{493}$ suggest that the receiver is not intended to be straightjacketed by formal adjudicative requirements.

Furthermore, the FHLBB has located the real adjudication of creditor claims above the level of the receiver. ${ }^{494}$ In doing so it must be relying upon its rulemaking authority under section $1464(\mathrm{~d})(11),{ }^{495}$ which itself contains no triggering terminology. 496 Hence we can conclude that the procedural provisions of the APA are triggered by neither the FSLIC's adjudicative authority nor the FHLBB's rulemaking authority. ${ }^{497}$

b. Judicial review. The Home Owners' Loan Act and the National Housing Act are silent on the apphicable scope of judicial review of the receiver's claims determinations. When endorsing the FSLIC's claim to exclusive adjudicatory jurisdiction, the court in Hudspeth noted that once the administrative process has been exhausted the claimant, "if unsatisfied, can seek judicial review under the APA."498 In fact, none of the courts that have apphed the Hudspeth doctrine have carefully analyzed the exact nature of this assumed review jurisdiction. ${ }^{499}$

493. See supra text accompanying note 250 .

494. See supra text accompanying notes $278-97$.

495. See supra text accompanying notes $427-29$.

496. See supra text accompanying note 187 (quoting section 1464 (d)(11) in full). In its proposed, interim and supplemental rules, see supra notes 201, 202, 205, the Board has relied variously on sections 1437 (whicl establislies the FHLBB and states its general regulatory mission), 1464(a) (which confers on the FHLBB its general chartering and supervisory powers), 1464(d)(ii) and 1729(d). See 53 Fed. Reg. 21,474, 21,475 (1988); 53 Fed. Reg. 13,105, 13,106 (1988); 50 Fed. Reg. 48,970, 48,971 (1985).

497. Anotlier possible trigger is the Constitution's due process clause. U.S. CoNsT. amend. V. The isolated precedent for this is Wong Yang Sung v. McGrath, 339 U.S. 33 (1950), in which the Court held that tle APA's requirement of formal adjudication was triggered if the hearings lield by the agency (in this case, on deportation) were lield "by compulsion" as opposed to "by regulation, rule, custom, or special dispensation." Id. at 50. This suggests that the FHLBB and FSLIC should conduct fornal adjudicatory learings. The trouble is that Wong Yang Sung is an unclear guide as to when the Constitution miglit trigger formal proceedings; moreover, it appears to have little precedential force, at least wliere personal hiberty is not at stake. Cf. Clardy v. Levi, 545 F.2d 1241 (9th Cir. 1970) (refusing to extend the reasoning in Wong Yang Sung to prison disciplinary proceedings). As the authors of a leading casebook liave observed, "[i]n practice . . . Wong Yang Sung appears to have fallen into obscurity." W. GelihoRN, C. BYSE, P. STraUSS, T. RAKOFF \& R. SchotLaND, ADMinistrative LAW 247 (8th ed. 1987); $c f$. S. BREYER \& R. STEWART, AdMINISTRATIVE LAW AND Regulatory Policy 870 (2d ed. 1985); R. Pierce, S. Shapiro \& P. Verkuil, AdminisTRATIVE LAW AND PRocess \$ 6.4 (1985).

498. Hudspeth, supra note 103, 756 F.2d at 1103 (citing First Sav. \& Loan Ass'n v. First Fed. Sav. \& Loan Ass'n, 531 F. Supp. 251, 254 (D. Haw. 1981) (stating tliat judicial review "may be available under section 10 of the Administrative Procedure Act, 5 U.S.C. §§ 701-706 (1976)")).

499. More attention las been paid to the scope of review involved in judicial challenges to the appointinent of conservators and receivers. In this context, judicial review is specifically provided for by the statute, 12 U.S.C. $\S 1464(d)(6)(A)$ (1982), which uses the phrase "upon the merits." See, e.g., Woods v. FHLBB, 826 F.2d 1400, 1406-09 (5th Cir. 1987) (asserting that Congress did not 
The Ninth Circuit, in Morrison-Knudsen, took the view that, "[i]n the absence of specific congressional direction," the "arbitrary and capricious" standard "might well be applicable . . . or at best the "substantial evidence' standard," which the court took to be more deferential than "weight of the evidence" review. .00 Similarly, the Texas court of appeals in Glen Ridge, ${ }^{501}$ ruling section 1729(d) to be an unconstitutional grant of adjudicative power partly because of the low level of judicial scrutiny on review, observed that neither of the APA's potentially applicable "arbitrary and capricious" 502 or "substantial evidence" 503 standards were as intense as the common law "weight of the evidence" or de novo review standards. ${ }^{504}$

Since Hudspeth adjudications are not required by statute to be made "after a hearing on the record," 505 the scope of review is governed by the "arbitrary and capricious" standard of review and not the "substantial evidence" standard. This would follow from the express statement in the APA that the"substantial evidence" standard should only apply "in a case subject to sections 556 and 557 of this title [i.e., formal adjudication] or otherwise reviewed on the record of an agency hearing provided by statute."506 In practice, however, because the FHLBB has developed a recordkeeping requirement for $H u d s p e t h$ adjudications, ${ }^{507}$ and, with the developinent of "hard look" review, 508 the scope of review is likely to be as probing under the "arbitrary and capricious" standard as it would

intend for the district court to review the Bank Board's decision de novo, but rather that the decision be reviewed on the basis of the administrative record in accordance with the APA's "arbitrary and capricious" standard), cert. denied, 108 S. Ct. 1221 (1988).

500. 811 F.2d 1209, 1221 (9th Cir. 1987), petition for cert. filed sub nom. FSLIC v. Stevenson Assocs., 56 U.S.L.W. 3249 (U.S. Sept. 17, 1987) (No. 87-451).

501. Glen Ridge I Condoniniums, Ltd. v. FSLIC, 734 S.W.2d 374 (Tex. Ct. App. 1986), writ denied, 750 S.W.2d 757 (Tex. 1988).

502. 5 U.S.C. $\$ 706(2)(A)(1982)$.

503. 5 U.S.C. $\$ 706(2)(E)$.

504. 734 S.W.2d at 380, 389. The district court in Lyons rehed on legislative history in assuming that the standard of review intended by Congress is actually the "weight of the evidence" standard. See Lyons Sav. \& Loan Ass'n v. Westside Bancorporation, 636 F. Supp. 576, 580 (N.D. Ill. 1986) (quoting H. REP. No. 2077, supra note 402, at 6), aff'd, 828 F.2d 387 (7th Cir. 1987); accord Peoples' Sav. \& Loan Ass'n v. First Fed. Sav. \& Loan Ass'n, 677 F. Supp. 1104, 1107-08 (D. Kan. 1988). But Lyons is wrong in two respects. First, the legislative history referred to by the court rclated to a specific "weight of the evidence" provision in the House bill, whereas the Senate bill, which merely adopted the provisions of the APA, contained the review provisions that Congress eventually enacted. Second, in the legislative history cited by the Lyons court, the House conimittee was concerned only with the special adjudicatory procedures it had established in relation to cease and desist orders and appointment and renoval of directors. See supra note 402.

505. See supra text accompanying notes $489-93$.

506. 5 U.S.C. $\$ 706(2)(E)$.

507. See supra text acconipanying notes 262-69.

508. See generally, e.g., R. Pierce, S. Shapiro \& P. VerkuIL, supra note 497, § 7.5, at 377-88. 
have been under the "substantial evidence" standard. ${ }^{509}$

\section{B. Constitutional Constraints.}

Even if there is statutory authority for the Hudspeth scheme, the scheme will be invalid if it violates the Constitution. On the other hand, this article considers not only whether the existing scheme might violate the Constitution, but also with whether, if so, it can be modified so as to comply with the Constitution. If the scheme violates article III, for example, we should then consider whether there is a way in which the procedures inight be structured so as to coinply with its requirements. If there is not, then the FHLBB and the FSLIC must accept that the validity of creditor claims simply cannot be adjudicated administratively without judicial participation.

1. Constitutionalism in the Administrative State. The task of reconciling agency government with the constraints imposed by the Constitution has proven perplexing and recurrent. Something of a pattern has emerged during the course of the past six decades. The Supreme Court has first reacted agamst the presence of agency authority by vigorously reasserting formal constitutional doctrines. Then, perceiving that it has overreacted and thereby placed the orderly functioning of modern government in jeopardy, it has assumed a more pragmatic or "functional" approach that has ultimately rendered the formal doctrine virtually dorinant. 510

This pattern of resistance, followed by acquiescence, has manifested itself in various contexts. The "constitutional fact" 511 and "jurisdictional fact" 512 doctrines, which once appeared to create insuperable obstacles to exclusive admmistrative decisionmaking, seem long moribund. ${ }^{513}$ The

509. See Association of Data Processing Serv. Orgs. v. Board of Governors, 745 F.2d 677, 68186 (D.C. Cir. 1984). In Data Processing, Judge Scalia reasoned that the difference between the two standards was related not to the level of rationality that must be exhibited by an agency's decision, but to the material that may be considered by the court in its review: formal adjudications must be judged solely by the closed record that the agency was required to develop. Apart from this, the distinction between the standards is "largely semantic." See also R. PIERCE, S. Shapiro \& P. VERKUIL, supra note $497, \S 7.3 .3$.

It is recommended, however, that judicial review be confined to the record, and therefore elevated to the "substantial evidence" standard, because of the fact-speeific nature of creditor claims. See infra text accompanying note 748.

510. Cf. Rabin, Federal Regulation in Historical Perspective, 38 STAN. L. REv. 1189 (1986) (examining the dominant themes that emerge from an overview of the evolution of the federal regulatory system and the judicial response to each successive wave of regulatory change).

511. See, e.g., Ohio Valley Water Co. v. Ben Avon Borough, 253 U.S. 287 (1920).

512. See, e.g., Crowell v. Benson, 285 U.S. 22 (1932).

513. See generally, e.g., R. PiERCE, S. Shapiro \& P. VerkuIL, supra note 497, $\$ 5.2 .2$ (discussing the demise of the Ben Avon and Crowell doctrines). 
nondelegation doctrine, which wrought such havoc with the first phase of the New Deal, ${ }^{514}$ now functions as no more than a docile admonition against the expansive delegation of statutory power to agencies. ${ }^{515}$ The restraints imposed upon agency adjudication by article III quite recently seemed forinidable; yet, even at a time when the Court has taken an unusually strict view of the Constitution in its application to the first branch of government, ${ }^{516}$ article III has subsequently proved renarkably flexible. 517 The application of procedural due process to agencies has evolved into ad hoc judicial judgments as to the fairness of specific procedures. 518

In relevant respects, the Court appears to have shifted from a formalistic approach to a functional one. When deciding on the constitutionality of admnistrative institutions and schemes, the Court has adopted an interest-balancing approach. ${ }^{519}$ The new approach has niade it necessary to attenipt to predict the likely outcome of constitutional challenges by anticipating which interests the Court is likely to take into account when performing its balancing exercise, as well as the relative weight that each interest will receive. The results are likely to be heavily dependent on the facts in eảch type of case.

\section{The Network of Constraints.}

a. Delegation of powers. The power to adjudicate creditor claims could be challenged as an unconstitutional delegation on two levels. First, the basic authority to establish the claims determination scheine might be attacked as an unconstitutional delegation of power to the FHLBB. Alternatively, it might be claimed that, when adjudicating creditor clainis, the FHLBB and the FSLIC exercise a standardless discretion and that this constitutes an unlawful delegation of power by Congress. The courts in which the delegation issue has been raised have not

514. See Carter v. Carter Coal Co., 298 U.S. 238 (1936); A.L.A. Schechter Poultry Corp. v. United States, 295 U.S. 495 (1935); Panama Refining Co. v. Ryan, 293 U.S. 388 (1935). See generally, e.g., R. PIERCE, S. Shap1Ro \& P. Verku1L, supra note 497, $§ 3.4 .2$ (discussing the New Deal cases).

515. See infra notes 522-24 and accompanying text.

516. See, e.g., Bowsher v. Synar, 478 U.S. 714 (1986); INS v. Chadha, 462 U.S. 919 (1983); Buckley v. Valeo, 424 U.S. 1 (1976).

517. Cf. Bruff, On the Constitutional Status of the Administrative Agencies, 36 AM. U.L. REv. 491, 502-04 (1987); Strauss, Formal and Functional Approaches to Separation-of-Powers QuestionsA Foolish Inconsistency?, 72 CoRNell L. ReV. 488 (1987).

518. See infra notes $609-10$ and accompanying text.

519. See, e.g., Commodity Futures Trading Coinm'n v. Schor, 478 U.S. 833 (1986) (discussed infra in text accoinpanying notes 576-88). See generally Aleinikoff, Constitutional Law in the Age of Balancing, 96 YALE L.J. 943 (1987). 
clearly distinguished between these two potential objections. ${ }^{520}$

The entire Hudspeth scheme has been implemented as part of the Board's general regulatory authority under 12 U.S.C. section 1464(d)(11). ${ }^{521}$ Broad though this regulatory authority is, however, an attack upon its constitutionality has probably long been obviated by Fahey v. Mallonee, ${ }^{522} \mathrm{~m}$ which such a challenge, made against the FHLBB's original authority to make rules governing thrift hquidations, ${ }^{523}$ was unsuccessful. The Court held that broad legislation enacted within the context of close and experienced regulation does not constitute an unconstitutional delegation of power:

The remedies which are authorized are not new ones unknown to existing law to be invented by the Board in exercise of a lawless range of power. Banking is one of the longest regulated and inost closely supervised of public callings. It is one in which accumulated experience of supervisors, acting for many states under various statutes, has established well-defined practices for the appointinent of conservators, receivers and hquidators. Corporate inanagenent is a field, too, in which courts have experience and many precedents have crystallized into well-known and generally acceptable standards. A discretion to make regulations to guide supervisory action in such matters may be constitutionally permissible while it might not be allowable to authorize creation of new crimes in uncharted fields. ${ }^{224}$

Although Fahey was concerned with the appointment of a conservator, the Court's ruling on the constitutionality of the FHLBB's regulatory authority is probably dispositive in the present context as well, and has been so regarded by those district courts that have been presented with

520. See, e.g., Baer v. Abel, 648 F. Supp. 69, 78 (W.D. Wash. 1986); First Am. Sav. Bank, F.S.B. v. Westside Fed. Sav. \& Loan Ass'n, 639 F. Supp. 93, 100 (W.D. Wash. 1986); American Fed. Sav. \& Loan Ass'n v. Westside Fed. Sav. \& Loan Ass'n, No. C-85-323-C, slip op. (W.D. Wash. Feb. 4, 1986), reprinted in Stevenson Petition, supra note 142, at 48a-49a, rev'd, Morrison-Knudsen Co. v. CHG Int'l, Inc., 811 F.2d 1209 (9th Cir. 1987), petition for cert. filed sub nom. FSLIC v. Stevenson Assocs., 56 U.S.L.W. 3249 (U.S. Sept. 17, 1987) (No. 87-451).

521. 12 U.S.C.A. $\$ 1464$ (d)(11) (West Supp. 1988); see supra text accompanying note 187 (quoting $\S 1464$ (d)(11) in full).

522. 332 U.S. 245 (1947).

523. See supra text accompanying note 366 . Congress has subsequently addressed the scope of this regulatory authority more specifically. See 12 U.S.C.A. $\$ 1464(d)(11)$ (West Supp. 1988) (FHLBB may regulate thrift hquidations); see also supra text accompanying notes 404-06.

524. 332 U.S. at 250. Fahey represents one of the Court's first attempts to pull back from its enforcement of the nondelegation doctrine established in Panama Refining Co. v. Ryan, 293 U.S. 388 (1935), and A.L.A. Schechter Poultry Corp. v. United States, 295 U.S. 495 (1935). The Court was able to distinguish both cases casily. The Board's regulatory authority did not entail "a power to make federal crimes of acts that never had been such before," it did not enable the Board "to devise novel rules of law in a field in which there had been no settled law or custom," and it did not involve the delegation of governmental power "to private groups as well as to public authorities." Fahey, 332 U.S. at 249 . On the contrary, the provisions were "regulatory," dealing "with a single type of enterprise and with the problenss of insecurity and mismanagement that are as old as banking enterprise." Id. at 250. 
this issue. 525

The second line of attack seems equally futile and perhaps even misconceived. The argument here is that the adjudicatory power assertedly conferred by section 1729 (d) is standardless. This objection has some credibility as a result of the decision in Thomas v. Union Carbide Agricultural Products Co., $^{526} \mathrm{~m}$ which nondelegation and article III challenges were mounted against the Environmental Protection Agency's arbitral jurisdiction under the Federal Insecticide, Fungicide, and Rodenticide Act. ${ }^{527}$ The appellees had argued that the Act's standard for coinpensation was so vague as to give "a significant case-by-case lawinaking function to the arbitrator in compensation disputes" 528 and that this represented an unconstitutional delegation of legislative powers. While noting that the legislation, which "appears vague on its face[,] 'Inay derive much meaningful content from the purpose of the Act, its factual background, and the statutory context," "529 and that the legislative history of the legislation was "far from silent," 530 the Court left the issue open for determination on remand.

Apparently confronted by a similar argument in the present context, one district court has assumed, citing Union Carbide, that the nondelegation challenge is "inapposite" 531 since it inore appropriately invokes article III than article I. ${ }^{532}$ Nevertheless, the success of such a challenge would depend upon the absence of any regulatory tradition, guiding case law, or meaningful judicial review. ${ }^{533}$ The availability now of a growing body of published reports on Hudspeth adjudications ${ }^{534}$ tends to undermine the argument that there are no adjudicatory standards. In any event it is highly unlikely, given the reluctance of the Court to invoke the

525. See, e.g., Baer v. Abel, 648 F. Supp. 69, 78 (W.D. Wash. 1986); First Am. Sav. Bank, F.S.B. v. Westside Fed. Sav. \& Loan Ass'n, 639 F. Supp. 93, 100 (W.D. Wash. 1986); American Fed. Sav. \& Loan Ass'n, No. C-85-323-C, reprinted in Stevenson Petition, supra note 142, at 50a.

526. 473 U.S. 568 (1985).

527. 7 U.S.C. $\S \S 136,136 \mathrm{a}-136 y$ (1982 \& Supp. IV 1986).

528. 473 U.S. at 601-02 (Brennan, J., concurring).

529. Id. at 593 (quoting American Power \& Light Co. v. SEC, 329 U.S. 90, 104 (1946) (as modified)).

530. Id.

531. First Am. Sav. Bank, F.S.B. v. Westside Fed. Sav. \& Loan Ass'n, 639 F. Supp. 93, 100 (W.D. Wash. 1986); see also American Fed. Sav. \& Loan Ass'n, No. C-85-323-C, reprinted in Stevenson Petition, supra note 142 , at $48 a-49$ a.

532. The court wrongly assumed that Union Carbide was concerned with an article III challenge alone, whereas in fact the Court in Union Carbide explicitly dealt with the nondelegation challenge. See Union Carbide, 473 U.S. at 593 ("Appellees raise article I as an altemative ground for sustaining the judgment ...." ").

533. See, e.g., Amalgamated Meat Cutters v. Connally, 337 F. Supp. 737, 746, 759-62 (D.D.C. 1971) (agency development of standards that facilitate public accountability and meaningful judicial review saves broad delegation of power).

534. See infra text accompanying note 705 . 
nondelegation doctrine, that such a challenge would succeed..$^{535}$

On the other hand, one of the trade-offs for tolerating broad delegations of power has been the intensification of judicial review; ${ }^{536}$ hence the article I objection, even if unsuccessful in itself, might serve to buttress arguments in favor of formal adjudicatory structures and the maintenance of a reliable record for the purposes of judicial review. ${ }^{537}$

b. Article III. The major constitutional objection to the Hudspeth sclieme so far is the charge that it violates the right of creditors to adjudication of their claims by an independent judiciary enjoying security of tenure and salary, as guaranteed by article III. ${ }^{538}$ This complaint played a decisive role, albeit in different ways, in MorrisonKnudsen ${ }^{539}$ and in Glen Ridge. ${ }^{540}$ In both cases the courts were aware of the recent Supreme Court applications of article III to administrative agencies. ${ }^{541}$ Article III was also relied upon, witliout success, by litigants in some of the otlier cases, ${ }^{542}$ including Hudspeth itself. ${ }^{543}$ The issue is now before the Supreme Court. ${ }^{544}$

535. As Professor Strauss has put it, “delegation arguments are desperation arguments in the current legal climate." Strauss, supra note 517, at 525 .

536. See, e.g., Bowen v. American Hosp. Ass'n, 476 U.S. 610 (1986). In Bowen, Justice Stevens explained that "hard look" judicial review is necessary because

our recognition of Congress' need to vest administrative agencies with ample power to assist in the difficult task of governing a vast and complex industrial Nation carries with it the correlative responsibitity of the agency to explain the rationale and factual basis for its decision, even though we show respect for the agency's judgnient in both.

Id. at 627; see also Ethyl Corp. v. EPA, 541 F.2d 1 (D.C. Cir.) (en banc), cert. denied, 426 U.S. 941 (1976). The Ethyl court held:

In the case of legislative enactments, the sole responsibility of the courts is constitutional due process review. In the case of agency decision-making the courts have an additional responsibility set by Congress. Congress has been willing to delegate its legislative powers broadly-and the courts have upheld such delegation--because there is court review to assure that the agency exercises the delegated power within statutory limits, and that it fleshes out objectives withim those limits by an administration that is not irrational or discriminatory. Nor is that envisioned judicial role ephemeral, as Overton Park makes clear.

Id. at 68 (Leventhal, J., concurring) (citation omitted).

537. See infra text accompanying notes 681-84.

538. "The Judges, both of the supreme and inferior Courts, shall hold their Offices during good Behaviour, and shall, at stated Times, receive for their Services, a Compensation, which shall not be diminished during their Continuance in Office." U.S. CoNST. art. III, $\S 1$.

539. 811 F.2d 1209 (9th Cir. 1987), petition for cert. filed sub nom. FSLIC v. Stevenson Assocs., 56 U.S.I.W. 3249 (U.S. Sept. 17, 1987) (No. 87-451); see supra text accompanying notes 124-31.

540. 750 S.W.2d 757 (Tex. 1988) (per curiam); see supra text accompanying notes 135-40.

541. Commodity Futures Trading Comm'n v. Schor, 478 U.S. 833 (1986); Thomas v. Union Carbide Agric. Prods. Co., 473 U.S. 568 (1985); Northern Pipeline Constr. Co. v. Marathon Pipe Line Co., 458 U.S. 50 (1982) (discussed infra in text accompanying notes 545-88).

542. See infra text accompanying notes 545-88.

543. See supra note 107.

544. See supra note 18 . It has long been settled that the discretionary power to place a financial institution in receivership and appoint receivers, as opposed to the power to determine the validity of 
(i) The evolution of an article III balancing test. After being unexpectedly rejuvenated as a formidable constraint on agency adjudicative power in the early 1980s, article III has, since 1985 and with the energence of a pragmatic majority in the Court, again lost much of its constraining force. ${ }^{545}$ Northern Pipeline Construction Co. v. Marathon Pipe Line Co. ${ }^{546}$ was the case in which a plurality of the Court ${ }^{547}$ gave the article its unexpected vitality; it was also the case in which the dissent ${ }^{548}$ espoused the pragmatic view that has subsequently attracted a majority in the Court.

In Northern Pipeline the Court declared unconstitutional a grant of jurisdiction over all civil proceedings arising under title 11 or arising in or related to cases under title 11 of the 1978 Bankruptcy Act. ${ }^{549}$ This jurisdiction had been vested in bankruptcy judges who enjoyed neither life tenure nor protection from diminution of salary, both of which are required by article III. Justice Brennan, speaking for the plurality, held that the bankruptcy jurisdiction violated article III for two reasons. First, it did not fall within one of the three established exceptions recognized by the Court in its article III jurisprudence. ${ }^{550}$ Second, bankruptcy judges could not be regarded as mere "adjuncts" of article III courts.

In Justice Brennan's view, the only conceivably relevant exception to the application of article III was the enigmatic "public rights" exception: if the subject nuatter of bankruptcy court jurisdiction involved socalled "public," as opposed to "private," rights, then article III would not apply. ${ }^{551}$ But, while Justice Brennan accepted that the restructuring

individual creditor claims, may be vested by statute in an agency without violating article III. E.g., Bushnell v. Leland, 164 U.S. 684, 685 (1897).

545. For a critical analysis of the shift toward pragmatism in the Court's application of article III to administrative agencies, see Fallon, Of Legislative Courts, Administrative Agencies, and Article III, I0l HARV. L. REV. 916 (1988).

546. 458 U.S. 50 (1982) (plurality opirion).

547. Brennan, J., joined by Marshall, Blackmun \& Stevens, JJ.

548. White, J., joined by Burger, C.J. \& Powell, J., dissented.

549. 458 U.S. at $84-85$ (plurality opinion). It is important to note that the Northern Pipeline holding extended only to the jurisdiction to adjudicate "traditional" state common law actions "not made subject to a federal rule of decision, and related only periplierally to an adjudication of bankruptcy under federal law." Id. at 92 (Burger, C.J., dissenting); see also id. at 90 (Rehnquist, J., concurring) (characterizing the suit in question (damages for breacli of contract, misrepresentation) as "the stuff of the traditional actions at comnion law").

550. The exceptions identified by Justice Brennan were those relating to territorial courts, courts-martial, and the adjudication of "public rights." See id. at 64-67 (plurality opinion).

551. Id. at 69-70 (plurality opinion). Justice Brennan, recognizing the uncertain distinction between "public rights" and "private rights," referred to Crowell v. Benson, 285 U.S. 22 (1932), in which examples of "public rights" were given. Sucl rights imvolved the "exercise of the congressional power as to interstate and foreign comnierce, taxation, imimigration, the public lands, public health, the facilities of the post office, pensions and payments to veterans." Crowell, 285 U.S. at 51 (plurality opinion). For a comprehensive review of the developnent of the probleniatic public 
of debtor-creditor relations itself "may well be a "public riglit," public riglits "obviously" did not mclude "state-created private rights, sucl as the right to recover contract damages." 552 Justice Brennan also declined the invitation to recognize bankruptcy jurisdiction as a special new exception. Bankruptcy judges had jurisdiction over too broad a range of questions, and the creation of furtlier exceptions would erode the protection of article III. "Ad hoc balancing" was to be eschewed. ${ }^{553}$

As to the possible "adjunct" status of bankruptcy courts, the plurality believed that to possess this status the adjudicative scheme had to involve "congressionally created riglits," 554 and that "the functions of the adjunct must be limited in such a way that 'the essential attributes' of judicial power are retained in the article III court."555 Bankruptcy judges, however, had been given jurisdiction over all civil proceedings related to title 11 cases, they issued final, binding and enforceable judgments, and they were subject only to the deferential "clearly erroneous" standard of review. Hence, too many attributes of judicial power liad been transferred to their hands. ${ }^{556}$

Justice White's dissent focused on the impracticality of trying to separate state and federal law claims in bankruptcy proceedings, ${ }^{557}$ and on the poverty of the "public rights/private rights" distinction. 558 Justice White instead advocated a pragmatic balancing approach, involving a weighing of the interest of Congress in "pursuing in this manner one of its constitutionally assigned responsibilities" agamst the values preserved by article III, witl the Court retaining "the final word on low that balance is to be struck."ss9

Justice White also adverted to an associated factor that is important for present purposes: namely, the interrelationship of article III with the due process clause. In his view, if a situation were to arise in which Congress nnight be tempted to influence the article I court, the due pro-

rights/private rights distinction, see Young, Public Rights and the Federal Judicial Power: From Murray's Lessee Through Crowell to Schor, 35 BufFalo L. REv. 765 (1986).

552. 458 U.S. at 71.

553. See id. at $72-74 \&$ n.28.

554. Id. at 78. The relationship, if any, between "public" rights and "congressionally created" rights was not explained.

555. Id. at 81. For example, in Crowell v. Benson, 285 U.S. 22 (1932), where the Court had treated a workers' compensation commissioner as an "adjunct," the Court retained full authority to deal with matters of law.

556. See 458 U.S. at 8486.

557. See id. at $96-98$ (White, J., dissenting).

558. See id. at 107-10.

559. See id. at 113-16. 
cess clause itself might then dictate the use of an article III court. ${ }^{560}$

The subsequent article III decisions, Thomas v. Union Carbide Agricultural Products Co. ${ }^{561}$ and Commodity Futures Trading Commission v. Schor, ${ }^{562}$ represent a major drift by a clear majority of the Court toward the position advocated in Justice White's Northern Pipeline dissent.

In Union Carbide an arbitration scheme established by the Environmental Protection Agency for the purpose of compensating the supphiers of data for use in subsequent registration proceedings was challenged. The scheine was compulsory and provided for judicial review only where the arbitrator's decision was alleged to be the result of "fraud, misrepresentation, or other misconduct."

The emphasis of the Court ${ }^{563}$ was upon the impossibility of applying article III in an absolute fashion and the consequent need to focus instead on the underlying policies of the article: the maintenance of judicial independence and impartiality. ${ }^{564}$ Turning to the "public rights/ private rights" analysis employed by the Northern Pipeline plurality, the Court noted that the "public rights/private rights" analysis had failed to command majority support ${ }^{565}$ and emphasized the pragmatic nature of any test to be applied in the application of article III: "practical attention to substance rather than doctrinaire reliance on formal categories should inform application of article III."566 Neither the extent of judicial

560. Id. at 117 (citing Crowell v. Benson, 285 U.S. 22, 87 (1932). In Crowell, Justice Brandeis had said, in dissent:

If there be any controversy to which the judicial power extends that may not be subjected to the conclusive determination of administrative bodies or federal legislative courts, it is not because of any prohibition against the dimunition of the federal district courts as such, but because, under the circumstances, the constitutional requirement of due process is a requirement of judicial process.

Crowell, 285 U.S. at 87.

On the other hand, this does not necessarily dictate de novo judicial review, since, as Justice

Brandeis had also observed in a later case:

The inexorable safeguard which the due process clause assures is not that a court may examine whether the findings [of fact] are correct, but that the trier of the facts shall be an inipartial tribunal; that no finding shall be made except on due notice and opportunity to be heard; that the procedure at the hearing shall be consistent with the essentials of a fair trial; and that it shall be condueted in such a way that there will be opportunity for a court to determine whether the apphicable rules of law and procedure were observed.

St. Joseph Stock Yards Co. v. United States, 298 U.S. 38, 73 (1936) (Brandeis, J., concurring). .

561. 473 U.S. 568 (1985).

562. 478 U.S. 833 (1986).

563. O'Connor, J., wrote for the majority.

564. See 473 U.S. at 582-83.

565. See id. at 586 .

566. Id. at 587 .

In essence, the public rights doctrime reflects simply a pragmatic imderstanding that when Congress selects a quasi-judicial method of resolving matters that "could be conclusively determined by the Executive and Legislative Branches," the danger of encroaching on the judicial powers is reduced.

Id. at 589 (citing Northern Pipelinc Constr. Co. v. Marathon Pipe Line Co., 458 U.S. 50, 68 (1982)). 
review nor the identity of the parties should, on their own, function as determinative factors. ${ }^{567}$

Turning to the case at hand, Justice O'Connor articulated a number of factors that, in combination, indicated that there had been no violation of article III. First, coinpensable use of the registrants' data 'serves a public purpose as an integral part of a program safeguarding the public health," and in this respect the riglt to coinpensation bore "inany of the characteristics of a 'public' right." 568 Second, the scheme represented "a pragmatic solution to the difficult problem of spreading the costs of generating adequate information regarding the safety, health, and environinental inpact of a potentially dangerous product," one that did "not diminish the likelihood of impartial decisionmaking."569 Third, given "the nature of the right at issue and the concerns motivating the Legislature," and in view of the "obvious purpose of the legislation to furnish a prompt, continuous, expert and inexpensive method for dealing with a class of questions of fact that are peculiarly suited to examination and determination by an administrative agency specially assigued to that task," 570 the Court did "not think this systein threatens the independent role of the Judiciary in our constitutional sclieme."571 Fourtl, the scheme incorporated "its own systein of internal sanctions," relying ouly tangentially upon the judicial branch for enforcement; in such cases the danger of Congressional or Executive encroachment was at a miniinum. ${ }^{572}$ Fimally, there was some judicial review, "including whatever review is independently required by due process considerations."573 The combination of these factors led the Court to conclude that:

Congress, acting for a valid legislative purpose pursuant to its constitutional powers under Article I, nay create a seemingly "private" right that is so closely integrated into a public regulatory scheme as to be a matter appropriate for agency resolution with limited involvement by the Article III judiciary. To hold otherwise would be to erect a rigid and formalistic restraint on the ability of Congress to adopt innovative measures such as negotiation and arbitration with respect to rights created by a regulatory scheme. ${ }^{574}$

567. See id. at 587-89.

568. Id. at 589.

569. Id. at 590.

570. Id. (quoting Crowell v. Benson, 285 U.S. 22, 46 (1932)).

571. Id.

572. Id. at 591 .

573. Id. at 592-93. In this regard Justice O'Connor somewhat vaguely referred to "review of constitutional error," to the constitutional fact doctrine mentioned, equally vaguely, by Chief Justice Hughes in Crowell, 285 U.S. at 46, and to Justice Brandeis' dissent in Crowell, 285 U.S. at 87 (quoted supra note 559).

574. Id. at 593-94. 
Although eight Justices agreed that the arbitral scheme did not violate article III, the number supporting the "public rights/private rights" analysis had dwindled to three. 575 In the next case, Commodity Futures Trading Commission v. Schor, ${ }^{576}$ the balancing approach attracted the concurrence of Justice Stevens as well and was therefore embraced by an even greater majority of the Court. 577

Schor involved agency adjudication of a state-law counterclaim and hence, unlike Union Carbide, where the claim was based on federal law, involved claims that fell squarely within the zone of "private rights" identified by the Northern Pipeline plurality. Justice O'Coimor reiterated that "practical attention to substance rather than doctrinaire rehance on forinal categories should inform application of Article III,"578 and that "bright line rules cannot effectively be employed to yield broad principles applicable in all Article III inquiries." 79 The constitutionality of the adjudicative scheme should be "assessed by reference to the purposes underlying the requirements of Article III," namely, the preservation of the independence of the judiciary and assurance of an impartial adjudicator in specific disputes. ${ }^{580} \mathrm{~A}$ pragmatic judgment had to be made, one that involves weighing "a number of factors, none of which has been deemed determinative, with an eye to the practical effect that the congressional action will have on the constitutionally assigned role of the federal judiciary." 581 More specifically, the Court articulated four factors to be weighed in the balance:

575. Justice Brennan (joined by Justices Marshall and Blackmun) was able to concur by employing his Northern Pipeline "public rights/private rights" analysis, concluding that the determinative feature of the claims in Northern Pipeline was the fact that they were created by state law and hence were clearly private rights protected by article III. See 473 U.S. at 597 (Brennan, J., concurring).

The claim in the Union Carbide case, on the other hand, involved a public right, since the dispute arose

in the context of a federal regulatory scheme that virtually occupies the field. . . . Although a compensation dispute under FIFRA ultinately involves a determination of the duty owed one private party by another, at its heart the dispute involves the exercise of authority by a Federal Government arbitrator in the course of administration of FIFRA's comprehensive regulatory scheme. As such it partakes of the characteristics of a standard agency adjudication.

Id. at 600-01 (Brennan, J., concurring). Justice Stevens concurred on other grounds. Id. at 602

(Stevens, J., concurring).

576. 478 U.S. 833 (1986).

577. Justice O'Connor again gave the opinion of the Court. Justice Brennan, joined by Justice Marshall, was this time forced to dissent.

578. 478 U.S. at 848 (quoting Union Carbide, 473 U.S. at 587).

579. Id. at 857 .

580. $I d$. at 848. The former purpose was prinarily structural and nonwaivable, being concerned with the constitutional scheme as a whole, and the latter primarily personal and waivable, being concerned with protecting the inmediate parties to litigation. The Court found that Schor had in fact waived this latter right. See id. at 849-50.

581. Id. at 851 . 
[(i)] the extent to which the "essential attributes of judicial power" are reserved to Article III courts, and, conversely, [(i)] the extent to which the non-Article III forum exercises the range of jurisdiction and powers normally vested only in Article III courts, [(iii)] the origins and importance of the right to be adjudicated, and [(iv)] the concerns that drove Congress to depart from the requirements of Article III..$^{582}$

Applying this weighing process, Justice O'Connor noted that the jurisdiction to adjudicate common law connterclaims involved only a "single deviation froin the agency inodel," 583 that the CFTC deals only with a "particularized area of law" 584 that the review of the CFTC by article III courts was closer than in Northern Pipeline, and that the range of jurisdiction and powers exercised by the CFTC was much narrower than that of the bankruptcy courts in Northern Pipeline. ${ }^{585}$ As to the nature of the claim itself, the fact that it fell squarely within the zone of "private rights" was not itself dispositive. Instead, the fact that it was a type of claim that historically would have been adjudicated by article III courts was merely an indication that the danger to the judicial power was greater than would be the case with "public rights." 586 The availability of a parallel article III jurisdiction invokable by the parties anneliorated the significant threat to the judiciary. Finally, the congressional purpose was lionorable. ${ }^{587}$ Hence "the magnitude of any intrusion on the Judicial Branch can only be termed de minimis." 588

(ii) Implications for the Hudspeth procedures. The Court lias thus articulated several factors that liave to be weighed before coming to a final judgment on the constitutionality of the Hudspeth administrative sclieine. The Texas court of appeals in Glen Ridge 589 thouglit that the Hudspeth scheme simply fell short of meeting these requireinents. The FSLIC failed to satisfy the criteria necessary to be regarded an "adjunct" of the courts. ${ }^{590}$ There were insufficient safeguards to justify a departure

582. Id.

583. $I d$.

584. Id. (quoting Northern Pipeline, 458 U.S. at 85 ).

585. Id. at $852-53$.

586. See id. at 853-54.

587. "When Congress authorized the CFTC to adjudicate counterclaims, its primary focus was on making effective a specific and limited federal regulatory scheme, not on allocating jurisdiction among federal tribunals. Congress intended to create an inexpensive and expeditious alternative forum ...." Id. at 855 .

588. Id. (enphasis in original).

589. Glen Ridge I Condominiums, Ltd. v. FSLIC, 734 S.W.2d 374 (Tex. Ct. App. 1986), aff'd, 750 S.W.2d 757 (Tex. 1988) (per curiam); see supra text accompanying notes 135-40.

590. See 734 S.W.2d at 385-86 (focusing primarily on the executive appointment and creation of FSLIC officers and offices, the absence of supervisory control by article III judges and the narrow scope of judicial review, the absence of contempt powers on the part of the FSLIC, the breadth of subject matter jurisdiction asserted by the FSLIC, and the nonstatutory nature of the rights in issue). 
from normal article III requirements. Unlike Schor, creditors have no choice in selecting who will adjudicate their claims. ${ }^{591}$ The allocation of powers between the FSLIC and the article III courts is lopsided, with the courts being totally precluded, if section $1464(d)(6)(C)$ is apphicable, ${ }^{592}$ from exercising any supervisory review. ${ }^{593}$ The limited judicial review recognized in Hudspeth is much narrower than had obtained in Schor. ${ }^{594}$ Finally, whereas in Schor the parallel availability of access to the courts had rendered fair the balance that had been struck between a proper respect for traditional "private" rights and the need for their expeditious adjudication, the compulsory preclusion of the courts under the Hudspeth doctrine rendered FSLIC adjudication constitutionally impermissible. 595

To these considerations one might add the fact that in neither Union Carbide nor Schor was there serious dispute about the intention of Congress. The "concerns motivating the Legislature," 596 the "obvious purpose of the legislation,"597 and the exphicit authority that Congress had provided to adjudicate counterclaims, ${ }^{598}$ were factors specifically rehed upon by the Court in adopting the view that a departure from article III was justified. In the Hudspeth context, on the other hand, the legislative purpose of Congress is far froin evident. ${ }^{599}$

The Glen Ridge court of appeals' analysis of the present Hudspeth scheme seems fair. Yet the determinative criteria are interdependent in the sense that subtle readjustments to the relevant procedures and structures might well produce a formula that, on balance, would satisfy the cumulative demands of article III. With clear statutory authority, and the provision of safeguards desigued to ensure fair, impartial adjudication and adequate judicial supervision, it would be possible for Congress and the FHLBB to construct a constitutionally acceptable administrative claims adjudication scheme. ${ }^{600}$

c. Due process. The Hudspeth doctrime has been challenged under the due process clause for failure to provide an adequate hear-

591. See id. at 388.

592. See supra text accompanying notes $423-25$.

593. 734 S.W.2d at $388-89$.

594. Id. at 389.

595. Id. at 389-90.

596. See Thomas v. Union Carbide Agric. Prods. Co., 473 U.S. 568, 590 (1985); supra text accompanying note 570 .

597. See Thomas, 473 U.S. at 590 (quoting Crowell v. Bensol, 285 U.S. 22, 46 (1932)).

598. See supra text accompanying notes 427-29.

599. See supra text accompanying notes $362-429$.

600. This was recognized by the court in Morrison-Knudsen. See supra notes 126-30 and accompanying text. 
ing, ${ }^{601}$ and for violating the principle of an impartial hearing. ${ }^{602}$ Both challenges have failed in the lower courts thus far, ${ }^{603}$ although it is possible that the Supreme Court will address thein. ${ }^{604}$ In any event, many judges have only dismissed the due process claims on ripeness grounds, so it is likely that these questions will return to the courts again.

It is important to distinguish between the two kinds of due process challenge that have been made: the charge that the Hudspeth procedures are inadequate implicates quite different considerations froin those implicated by the charge that the FSLIC suffers from a conflict of interest when determining the validity of creditor claims.605 Another general observation shonld also be made: as with the nondelegation doctrine and article III jurisprudence, the Court has adopted a pragmatic approach when judging these two facets of due process. The adequacy of adminis-

601. See FSLIC v. Florida 100 Dev. Group, 670 F. Supp. 1577, 1583 (S.D. Fla. 1987) (no opportunity to present testinıony or cross-examine witnesses; claim dismissed as not being ripe); Baer $v$. Abel, 648 F. Supp. 69, 78 (W.D. Wash. 1986) (no opportunity to cross-examine witnesses or present testimony; claim dismissed as prenıature).

602. See Coit Independence Joint Venture v. FirstSouth, F.A., 829 F.2d 563, 564-5 (5th Cir. 1987) (claim that FSLIC will act as party and judge disposed of by decision in Woods v. FHLBB, 826 F.2d 1400 (5th Cir. 1987), cert. denied, 108 S. Ct. 1221 (1988)), cert. granted sub nom. Coit Independence Joint Venture v. FSLIC, 108 S. Ct. 1105 (1988); Florida 100 Dev. Group, 670 F. Supp. at 1583 (due process claim dismissed as not yet ripe); Baer, 648 F. Supp. at 78 (due process claim that FSLIC is an interested adjudicator dismissed as premature); First Am. Sav. Bank, F.S.B. v. Westside Fed. Sav. \& Loan Ass'n, 639 F. Supp. 93, 99-100 (W.D. Wash. 1986) ("assertion that FSLIC is likely to prefer its own interests over their claims is rebutted by the presumption that FSLIC acts in the best interests of the whole estate"); Modern Supply Co. v. FSLIC, 50 Wash. App. 194, 205, 748 P.2d 251, 257-58 (Wash. Ct. App. 1987) (charge that "it is unfair if the FSLIC is empowered to hear claims where its interests are adverse to the clainiant's" rejected because of existence of adequate administrative appeal to FHLBB and recourse to judicial review under APA).

603. But cf. Tocci Corp. v. Yankee Bank for Fin. \& Sav., FSB, No. Civ. A. 87-3121-K (D. Mass. 1988) (Westlaw, 1988 WL 70344). The Tocci court stated:

The conclusion[ ] . . . that the FDIC and FSLIC do not have exclusive jurisdiction to adjudicate creditor clainis in savings bank receiverships is] reinforced by the observation that allowing any person or entity to adjudicate claims against itself is an extraordinary arrangenent because of the inherent conflict of interest imphicit in such a dual role. An interpretation of a statute that attributes to Congress a nuanifestation of intent to create powers in an agency so likely to lead to impairment of impartiality in adjudication is inherently suspect.

Id.

604. Certiorari has been granted in one case that presents these issues directly. Coit Independence Joint Venture v. FirstSonth, F.A., 829 F.2d 563 (5th Cir. 1987), cert. granted sub nom. Coit Independence Joint Venture v. FSLIC, 108 S. Ct. 1105 (1988) (discussed supra at notes 17-18).

605. This distinction was not drawn by the Fifth Circuit in its decision in Coit. See id. The court relied on a deeision involving the adequacy of a hearing in disnissing Coit's complaint based upon conflict of interest. Id. at 565 (referring to Woods, 829 F.2d at 1410-13). Quite apart from the relevancy of the Woods decision to the statutory context in question (Woods involved the procedures governing the appointnent of a receiver, whereas the present issue concerns the adjudication, by a validly appointed receiver, of creditor clains), Woods did not deal with the question whether the FSLIC's procedures required an inpartial adjudicator. See Petition for Writ of Certiorari at 19 n.8, Coit Independence Joint Venture v. FSLIC, 108 S. Ct. 1105 (1988) (No. 87-996). 
trative procedures is judged by an ad hoc balancing test, ${ }^{606}$ and even in cases of alleged conflict of interest the Court has indicated that ad hoc evaluation is necessary in each case. 607

(i) Adequacy of the hearing. Procedural due process, to the extent that it is triggered by the the kinds of claims filed by creditors, 608 inay well mandate certain procedural requirements even if the FSLIC's determinations are regarded as a species of informal adjudication. Under the balancing approach articulated by the Court in Mathews v. Eldridge, ${ }^{609}$ the requirements of procedural due process will vary froin case to case, according to the private interest at stake, the efficacy of the existing procedures and the extent to which new procedures will produce more accurate decisions, and the cost to the government in implementing these procedures. ${ }^{610}$

The Mathews three-part balancing test has often been criticized; it hardly suggests an obvious answer in each case. Instead, it dictates yet another ad hoc balancing test to determine exactly what an agency is required to do to meet constitutional requirements. Perhaps the most widely accepted set of guidelines are those articulated shortly before the Mathews decision by the late Judge Henry Friendly. ${ }^{611}$ He thought the following constitute, "roughly in order of priority," 612 the elements of a fair hearing: an unbiased tribunal; notice of proposed action and the grounds asserted for it; an opportumity to present reasons why the proposed action should not be taken; the right to call witnesses; the right to

606. See infra notes $609-10$ and accompanying text.

607. See infra notes $622,631-33$ and accoinpanying text.

608. Claims grounded in contract would represent constitutionally protected property interests, see, e.g., Perry v. Sindermann, 408 U.S. 593, 599-601 (1972) (holding that a person may be deprived of a right created by contract only if due process requirements have been inet); Board of Regents $v$. Roth, 408 U.S. 564, 578 (1972) (holding that the requirenents of procedural due process did not apply to teaching appointment that did not create a property interest), but it is not clear whether those grounded in tort would be sufficient to implicate either property or biberty interests. See, eg., Paul v. Davis, 424 U.S. 693, 712 (1976) (common law defamation does not rise to level of a constitutional cause of action unless it results in a deprivation of "liberty" or "property" recognized by state or federal law). Nor, even if they are, is it clear whether anything more than a right of action in tort is required by due process. See, e.g., Ingraham v. Wright, 430 U.S. 651, 682-83 (1977) (right to bring action in tort deemed sufficient due process). Certainly those based on negligence would not. See Davidson v. Cannon, 474 U.S. 344 (1986) (due process protection ouly implicated where intentional government deprivation of protected interests involved); Daniels v. Williams, 474 U.S. 327 (1986) (same).

Given the sweep of the Hudspeth doctrine, however, the doctrine's coverage in relation to contractual claims alone justifies evaluation of the Hudspeth procedures agaiust due process standards.

609. 424 U.S. 319 (1976).

610. Id. at 335 .

611. Friendly, "Some Kind of Hearing," 123 U. PA. L. Rev. 1267 (1975).

612. Id. at 1278 . 
know the evidence against one; the right to have the decision based only on the evidence presented; the right to counsel; the making of a record; a statement of reasons; public attendance; and judicial review. ${ }^{613}$

Judge Friendly also suggested a hierarchy of adverse governmental action, ${ }^{614}$ from most to least severe, that would demand adherence to these procedures to a greater or lesser extent. ${ }^{615} \mathrm{He}$ ranked decisions such as those involving personal hiberty (e.g., parole) at the most severe end of the spectrum, and decisions involving governmental benefits at the least severe end. We can assume he would have placed receivership decisions near the middle of the spectrum, alongside those involving professional and trade licenses. In other words, receivership decisions rank as inoderately severe government action, and this would suggest that a substantial proportion of the elements of procedural due process identified by Judge Friendly should be considered in applying the Mathews balancing test.

(ii) Impartiality. The agencies administering the Hudspeth scheme are subject to two possible conflicts of interest. The first is pecumary, and the second steins froin the receiver's active involvement in both the affairs of the receivership in general and the determination of claims against the receivership.

The FSLIC, in its corporate capacity as insurer of thrift deposits, is nearly always the largest creditor in any thrift receivership. Since the FSLIC is also the receiver, this suggests a serious conflict of interest on the part of the receiver when it is determining the validity of the claims of other creditors. The potential conflict is rendered all the inore acute by the current pressure on the imsurance fund.616 Indeed, it is this very financial crisis that is offered as the prime justification for the administrative adjudicatory powers claimed under the Hudspeth doctrine.617 Hence, even if adjudication only takes place at the FHLBB level, the financial pressures might be too great to allow for impartial adjudication.

Since Dr. Bonham's Case ${ }^{618}$ at least, a financial interest, however small, in the outcome of one's decision has been regarded as a disqualifi-

613. Id. at $1279-95$.

614. The rejection of a claim filed against a receivership would be "adverse governmental action."

615. See id. at 1295-304.

616. See supra text accompanying notes 81-88.

617. See, e.g., Morrison-Knudsen Co. v. CHG Int'1, Inc., 811 F.2d 1209, 1216 (9th Cir. 1987), petition for cert. filed sub nom. FSLIC v. Stevenson Assocs., 56 U.S.L.W. 3249 (U.S. Sept. 17, 1987) (No. 87-451); Peoples' Sav. \& Loan Ass'n v. First Fed. Sav. \& Loan Ass'n, 677 F. Supp. 1104, 1108 (D. Kan. 1988); see also supra text accompanying notes 91-92.

618. 8 Coke's Rep. 114a, 77 Eng. Rep. 646 (C.P. 1610). 
cation from decisionmaking. ${ }^{619}$ The general proposition was restated in Tumey v. Ohio, ${ }^{620}$ where Chief Justice Taft observed: "That officers acting in a judicial or quasi judicial capacity are disqualified by their interest in the controversy to be decided is, of course, the general rule."621 $\mathrm{Nev}$ ertheless, the Court has always found it necessary to focus upon the "degree or nature of the interest" 622 and this necessarily imvolves a renewed assessment in each new set of circumstances in which a pecuniary imterest is alleged to violate due process.

In Tumey, the Court found that the due process clause had been violated for two reasons: first, because a inayor, who was also the judicial officer in cases imvolving prosecutions for violations of the state prohibition law, would only receive compensation for trying cases from the fines levied upon conviction of the defendants. ${ }^{623}$ Second, and inore important for our purposes (since there is no suggestion that inembers of the FHLBB or the FSLIC stand to gam im any personal way from the outcome of decisions made by thrift receivers), the Court found that there was a violation of due process because the legislative scheme had been deliberately constructed so as to "stimnlate small inunicipalities im the country part of counties in which there are large cities, to organize and maintaim courts to try persons aceused of violations of the Prohibition Act everywhere in the county." "624 In the absence of safeguards such as trial by jury, opportumity for a retrial, or broad judicial review, and given the mayor's mevitable interest "im the financial condition of the village, and his responsibility therefor," 625 the defendant could justifiably claim that he had been demied due process.

The importance of this second basis for the decision in Tumey is illustrated by the Court's more recent decision in Ward v. Village of Monroeville. ${ }^{626}$ Here the Court held that, even though the mayor-adjudicator did not stand to benefit personally and directly from the outcome of

619. Even the decision of a Lord Chancellor was set aside on this ground. See Dimes v. Grand Junction Canal, 3 H.L. Cas. 759, 10 Eng. Rep. 301 (1852). Financial interest should be contrasted with other potential sources of bias, such as prejudgment or generalized hostility; in the latter case it is much more difficult to establish a violation of due process. See, e.g., Aetna Life Ins. Co. v. Lavoie, 475 U.S. 813 (1986) (while a judge's general hostility toward the insurance industry would be insuffcient to constitute a violation of due process, the advantage the judge would gain from participating in a decision that would enhance the prospects of success in his own litigation pending in other courts was enough to vitiate the decision).

620. 273 U.S. 510 (1927).

621. Id. at 522 .

622. Id.

623. See id. at 531-32.

624. Id. at 532.

625. Id. at 533 .

626. 409 U.S. 57 (1972). 
his decisions, the financial benefit to his municipality was so great as to constitute "a possible temptation to the average man as a judge to forget the burden of proof required to convict the defendant, or which might lead him not to lold the balance mice, clear and true between the State and the accused." 627

The fact that botl Tumey and Ward involved criminal prosecutions is not a ground for distinguishing these cases. The Supreme Court has expressly stated that Tumey and Ward apply with equal force to situations involving administrative adjudication. 628

A conflict-of-interest objection to the FSLIC acting as both "prosecutor" and "adjudicator" is more difficult to sustain. In Withrow $v$. Larkin, ${ }^{629}$ the Court again articulated a pragmatic approach for evaluatming coinplaints that an agency has combined both investigatory and adjudicative functions. Though recognizing that a pecumary interest is one of those situations "in which experience teaches that the probability of actual bias on the part of the judge or decisionmaker is too high to be constitutionally tolerable,"630 Justice White noted that the problem of separating investigative from adjudicatory functions had been addressed by Congress in various ways" 631 and that " $[t]$ he incredible variety of administrative meclianisms in this country will not yield to any single organizing principle." 632 The test is whetlier the risk of bias or unfairness is "too high to be constitutionally tolerable." 633

This pragmatism again requires an evaluation of the actual $H u d-$ speth structures and suggests the possibility of devising a scheme that would satisfy constitutional constramts. The strictness with which the Court regards potential pecuniary conflicts of interest indicates that substantial adjudicative independence, and a meaningful separation between the receiver and adjudicator, are minimum requirements. ${ }^{634}$ These safeguards would also address the need to prevent a mixing of

627. Id. at 60 (quoting Tumey, 273 U.S. at 532 (1927)). That the Court in Tumey expressly extended the basis of its decision beyond the personal financial benefit enjoyed by the mayor was overlooked by Justice White in his dissent in Ward.

628. See Gibson v. Berryhill, 411 U.S. 564, 579 (1973).

629. 421 U.S. 35 (1975).

630. Id. at 47.

631. One general solution is the APA's requirement in formal adjudications that einployees engaged in investigating or prosecuting may not also participate or advise in the adjudication. See 5 U.S.C. § 554(d) (1982).

632. 421 U.S. at 52.

633. Id. at 47.

634. See infra text accounpanying notes 700-08. The problem of striking the right balance when creating an internal separation of powers in an agency is perennial, and it requires fine adaptation to the circumstances of each case. See Asimow, When the Curtain Falls: Separation of Functions in the Federal Administrative Agencies, 81 ColUM. L. REv. 759 (1981). 
"prosecutorial," or investigatory, and adjudicative functions. On the other hand, such safeguards are probably also sufficient requirements. In Marshall v. Jerrico, Inc. ${ }^{635}$ the Court upheld the constitutionality of a scheine in which the Einployment Standards Administration was reimbursed for its costs froin the civil penalties levied by the Administration on child labor violators. Although the agency benefited financially from the determinations of its assistant regional administrator, no individual within the agency stood to benefit personally ${ }^{636}$ and alleged violators were provided with a full, de novo hearing before an independent administrative law judge. This procedure was deemed sufficient to satisfy the neutrality requirements of due process. ${ }^{637}$

d. Seventh amendment. The seventh amendment provides that "[i]n Suits at cominon law, where the value in controversy shall exceed twenty dollars, the right of trial by jury shall be preserved." Many of the clains filed against thrifts in receivership 638 are plainly derived froin "suits at cominon law," or are based upon statutes that have created "legal rights and reinedies" normally "enforceable in an action for damages in the ordinary courts of law."639 Examples of the former are actions for breacl of contract, negligent misrepresentation and civil fraud. Examples of the latter are civil RICO claims predicated upon crimes alleged to have been committed by the thrift or its agents. Both types would, in the absence of receivership, be tried to a judge and jury in state or federal courts liaving jurisdiction. 640

Hence it is not surprising that creditors challenging the Hudspeth doctrine have charged that the doctrime violates their riglt to a trial by jury. The first reported case in which this challenge was addressed (and rejected) was Baer v. Abel. ${ }^{641}$ More recently the challenge was raised in

635. 446 U.S. 238 (1980).

636. Id. at 250 .

637. Id. at $247-50$.

638. See supra text accompanying notes 225-37.

639. Curtis v. Loether, 415 U.S. 189, 194 (1974).

640. The seventh amendment applies only to federal proceedings. See Minneapolis \& St. L. R.R. v. Bombolis, 241 U.S. 211 (1916). See generally 2 R. Rotunda, J. NowAK \& J. Young, TrEatISE ON CONSTITUTIONAL LAW 256-58 \& n.12 (1986).

641. 648 F. Supp. 69 (W.D. Wash. 1986). Shareholders had commenced an action against a thrift, alleging violations of federal and state securities laws, RICO, and the Washington State Consumer Protection Act in the sale of the thrift's stock. The thrift was then placed into receivership by the FHLBB, and the FSLIC moved to dismiss the plaintiffs' claims. Judge Rothstein granted the motion, rejecting the charge that in so doing he was denying the plaintiffs their right to trial by jury. He reasoned that the amendment "does not apply in actions against the Federal Government," and that even if the United States had consented to be sued, it had not conceded the right to a jury trial. Id. at 77 (quoting Lehınan v. Nakshian, 453 U.S. 156, 160 (1981)). Furthermore, the judge reasoned, the Supreme Court "has frequently affirmed congressional authority to commit factinding 
Coit Independence Joint Venture v. FirstSouth, F.A. ${ }^{642}$ The Fifth Circuit rejected the seventh amendment challenge in Coit Independence as not being ripe, ${ }^{643}$ and the question is now before the Supreme Court. ${ }^{644}$ It is unlikely, however, that this challenge will be successful, both because the Court has proved tolerant of administrative adjudication with which a jury would be incompatible, and because receivership claims are likely, in any event, to be treated as "equitable."

(i) Supreme Court toleration. The seventh amendment challenge appears, from the jurisprudential history of its application, to depend at least partly on the success of the article III cliallenge. In other words, if an adjudicative scheine could be devised that was authorized by Congress and satisfied the constramts of article III, it is unlikely that the Court would rule that it remained invalid because it deuied the right to a jury trial.

This view is reflected in a recent dictum in Tull v. United States, ${ }^{645}$ where Justice Brennan remarked that "the Seventh Amendinent is not applicable to administrative proceedings." 646 For, although it was once conceded by the Court that the arguinent that "the right to a jury trial was never intended to depend on the identity of the forum to which Congress has cliosen to submit a dispute" was "well put,"647 the fact is that where Congress has chosen to vest the adjudicative power in the hands of an agency, the Court has refused to apply the seventh amendment.648 Where, on the other hand, Congress has chosen to place adjudication of

functions and initial adjudications to an administrative forum without violating the seventh amendment." Id. at 77-78 (citing Atlas Roofing Co. v. Occupational Safety \& Health Review Comm'n, 430 U.S. 442, 450-55 (1977)).

642. 829 F.2d 563 (5th Cir. 1987), cert. granted sub nom. Coit Independence Joint Venture v. FSLIC, 108 S. Ct. 1105 (1988).

643. 829 F.2d at 565 .

644. See supra note 18.

645. 107 S. Ct. 1831 (1987).

646. Id. at $1835 \mathrm{n} .4$ (echoing prior dicta to the same effect); see, e.g., Atlas Roofing, 430 U.S. at 450 ("at least in cases in which 'public rights' are being litigated . . . the Seventh Amendment does not prohibit Congress from assigning the factfinding function and initial adjudication to an administrative forum with which the jury would be incompatible"); Pernell v. Soutliall Realty, 416 U.S. 363, 383 (1974) ("the Seventh Amendment is generally inapplicable in administrative proceedings where jury trials would be incoinpatible with the wliole concept of administrative adjudication"); see also Curtis v. Loether, 415 U.S. 189, $194-95$ (1974); L. JAFFE, Judicial CoNTrol OF ADMINISTRATIVE ACTION 90 (1965) (observing that, even if to do so would satisfy the Constitution, it would not be feasible to attach juries to agencies because "the concept of expertise on which the administrative agency rests is not consistent with the use by it of a jury as fact finder").

647. Atlas Roofing, 430 U.S. at 457-58.

648. See id. at 460-61; NLRB v. Jones \& Laughlin Stecl Corp., 301 U.S. 1, $48-49$ (1937); Block v. Hirsl, 256 U.S. 135, 158 (1921); cf. Katclien v. Landy, 382 U.S. 323, 336-40 (1966) (bankruptcy court). 
the rights it has created in the hands of a district court, the Court has proved much more willing to find an infringement of the requirements of the seventh amendment. 649

Various explanations have been offered for not requiring a jury trial in the case of agency adjudication. In Block $v$. Hirsh the Court thought that if a rent commission's statutory power was clear and constitutional, the seventh amendment objection "amounts to hittle. To regulate the relation [of landlord and tenant] and to decide the facts affecting it are hardly separable."6so In National Labor Relations Board v. Jones \& Laughlin Steel Corp. the Board's power to order reinstatement of an employee and payment for timie lost was described as "not a suit at common law or in the nature of such a suit. The proceeding is one unknown to the common law. It is a statutory proceeding" imvolving the recovery of damages only as "an incident to equitable rehief."651 In Atlas Roofing Co. v. Occupational Safety \& Health Review Commission the Court rehed on the "public rights/private rights" distinction as a justification: the power of the agency to determine violations of safety standards, to issue abatement orders, and to assess civil penalties, was described as involving "public rights" based upon newly created "statutory obligations" and not entailing a right to a jury trial.652 These arguments probably also apply to an otherwise constitutional administrative claims adjudication scheine.

(ii) Equitable nature of the proceedings. The Court's relaxation of the literal requirements of the seventh amendment has been criticized as "seriously weakening the protection afforded by the seventh amendment."653 But even if the Court were to adopt a stricter approach it is unlikely that it would do so in the case of thrift receivership adjudications.

In Katchen v. Landy, 654 a seventh amendment challenge was made against the summary jurisdiction of a bankruptcy court to order the surrender of voidable preferences asserted and proved by a trustee in response to a claim filed by the creditor who had received the preferences. The Court rejected the challenge, concluding that "there is no Seventh Amendment right to a jury trial for determination of objections to

649. See, e.g., Tull v. United States, 107 S. Ct. 1831, 1835-39 (1987); Pernell, 416 U.S. at 363;

Curtis, 415 U.S. at 189.

650. 256 U.S. at 158.

651. 301 U.S. at 48.

652. See 430 U.S. at $449-61$.

653. Kirst, Administrative Penalties and the Civil Jury: The Supreme Court's Assault on the Seventh Amendment, 126 U. PA. L. REv. 1281, 1281 (1978).

654. 382 U.S. 323 (1960). 
claims." 655 The Bankruptcy Act "converts the creditor's legal claim into an equitable claim to a pro rata share of the res" and "the proceedings of bankruptcy courts are inherently proceedings in equity," to which the right to a jury trial does not extend. ${ }^{656}$ It is therefore unlikely that the right to a jury trial would extend to the analogous situation of claims adjudications in thrift receiverships. ${ }^{657}$

3. The Importance of Clear Statutory Authority, Standards, Internal Separation of Powers, Procedural Fairness and Adequate Judicial Scrutiny. The thrift industry is so intensely regulated ${ }^{658}$ that the $\mathrm{Hud}$ speth scheme might well pass the enigmatic "public rights/private rights" test even though creditors' claims often involve rights created by state law. 659 On the other hand, the Hudspeth scheme constitutes a sweeping assertion of jurisdiction over a very broad range of claims ${ }^{660}$ and therefore constitutes one of the most daring challenges to article III yet presented. ${ }^{661}$ For this reason, Congress, the FHLBB and the FSLIC have to ensure that they take fully into account the cluster of concerns driving current Supreme Court jurisprudence on the constitutionality of agency adjudication.

Though the Court has dictated general deference to agencies in the construction of their statutory powers, ${ }^{662}$ it has also rehed upon the clarity of congressional purpose when accepting a departure from the requirements of article III.663 Statutory ambiguity has also exphicitly and properly led the courts in Morrison-Knudsen and Glen Ridge to avoid the constitutional problems by adopting a narrow construction of the agencies' powers. ${ }^{664}$ This supports the recommendation that, even if the

655. Id. at 337.

656. See id. at $336-37$.

657. Katchen is something of an exception in a pro-jury line of cases. See, e.g., Ross v. Bernhard, 396 U.S. 531, 538-40 (1970) (emphasizing that the distinction between law and equity is not itself determinative and that a jury trial might be available even where the procedural device employed was originally equitable). Nevertheless, since Katchen addresses bankruptcy, which is so closely analogous to financial receiverships, it is likely that the case would control in the present context.

658. See supra text accompanying notes 40-51,342-419. As the Court once put it, the FHLBB "has promulgated regulations governing 'the powers and operations of every Federal savings and loan association from its cradle to its corporate grave." "Fidehty Fed. Sav. \& Loan Ass'n v. De la Cuesta, 458 U.S. 141, 145 (1982) (quoting People v. Coast Fed. Sav. \& Loan Ass'n, 98 F. Supp. 311, 316 (S.D. Cal. 1951)).

659. See supra text accompanying notes 225-37.

660. See id.

661. See supra notes 554-56, 584-85 and accompanying text (emphasizing the breadth of administrative jurisdiction as an important criterion).

662. See supra text accompanying notes 325-36.

663. See supra text accompanying notes 596-98.

664. See supra text accompanying notes 129-31, 135-37. 
FHLBB does have putative authority to establish the Hudspeth scheme, ${ }^{665}$ this authority, and the structure of the adjudicative scheme itself, should be stated in clearer terms by Congress. ${ }^{666}$

The absence of adjudicatory standards raises concern about the excessive delegation of powers ${ }^{667}$ and might lead the Court to construe the FHLBB's statutory mandate restrictively. Basic procedural fairness also requires clear notice of the procedures to be followed in determining claims. ${ }^{668}$ Together, these concerns suggest not only the publication of opinions arising out of Hudspeth adjudications (a practice that the FHLBB has already begun to address ${ }^{669}$ ) but also the desirability of detailed, final rules governing the detailed processes for creditor claims determinations. ${ }^{670}$

Although it is prepared to evaluate administrative arrangennents on an individual basis, ${ }^{671}$ the Court is concerned about the availability of an impartial adjudicator ${ }^{672}$ and, in particular, potential conflicts of interest, both financial and functional. ${ }^{673}$ It is also concerned with the fairness of the adjudicative procedure. ${ }^{674}$ These concerns indicate that Congress or, in the absence of congressional action, the FHLBB itself, should ensure that there is a genuine internal separation of powers between the receiver and the claims adjudicator, that the claims adjudicator should enjoy significant insulation from the pressures, both financial and administrative, that might otherwise be brought to bear during the course of a receivership, and that creditors should not be prejudiced by ex parte material not on the record.675

With regard to article III, the Court has repeatedly expressed concern that there should be no attempt by Congress to aggrandize itself, through agencies, at the expense of the judicial branch. ${ }^{676}$ This militates strongly against the assertion by the FHLBB and the FSLIC that creditor claims that have already been adjudicated by a court shonld be sub-

665. See supra text accompanying notes $427-29$.

666. See infra text accompanying notes 754-58 (Recommendation 1).

667. See supra text accompanying notes 526-35.

668. Cf. Friendly, supra note 611 , at 1278 ("more elaborate specification of ... [desirable procedural safeguards] may help to produce more principled and predictable decisions"). Judge Friendly's set of guidehines are set forth supra in text aecompanying notes 612-13.

669. See infra text accompanying note 705.

670. See infra text accompanying notes 764-65 (Rccommendation 4).

671. See supra text accompanying notes 622, 631-33.

672. See supra text accompanying note 564 .

673. See supra text accompanying notes 618-37.

674. See supra text accompanying notes 608-15.

675. See infra text accompanying notes 759-62 (Rccommendation 2).

676. See supra text accompanying notes 570-72, 588. 
mitted to the receiver for adjudication de novo. 677 The attempt by an agency not merely to assert primary jurisdiction but to place itself in an appellate position vis-a-vis the courts is surely a flagrant "aggrandizement" of power at the expense of the courts. 678 Furthermore, the notion of a losing party having the opportunity to "readjudicate" the claim against it surely raises the apparent conflict of interest to an intolerable level. 679 The assertion of such jurisdiction therefore seems to go beyond the constitutional limits of administrative adjudication. 680

Finally, one consistent concern, arising in the context of the nondelegation doctrime, ${ }^{681}$ article III, ${ }^{682}$ and due process, ${ }^{683}$ is that there be adequate judicial review of agency adjudication. If the administrative adjudication scheme is valid, de novo judicial review would be wastefully duplicative. But meaningful judicial review to guard against abuses of power by the administrative adjudicator is a necessity. This entails the development of a coherent and reliable record and clarification as to the standard of judicial review. 684

\section{Evaluation of the Hudspeth Process}

The basic contention of tlie FHLBB that an administrative adjudication process is preferable to the regular judicial process, has been accepted as a premise of this article. Yet this contention is itself a matter of controversy. For example, while it seems probable that administrative adjudication would ensure greater uniformity im the case of receiverships that are faced with claims from different judicial jurisdictions, there is no hard evidence to show that the Hudspeth process is indeed quicker, more efficient and less expensive than the judicial alternative. In the absence of public access to details concerning individual receiverships, which access the FHLBB and FSLIC liave so far refused to grant, ${ }^{685}$ one is forced to rely on the opinions in the agency itself.

Furthermore, even if it can be demonstrated that the Hudspeth process is more efficient and less expensive, this does not necessarily imply that it is as fair a process as that available in the courts. Without some

677. See supra notes 234-35 and accompanying text (citing cases in which the FSLIC attempted to avoid the effect of judgments already entered against thrifts).

678. See supra text accompanying notes 734-39.

679. See supra text accompanyming note 630.

680. See infra text accompanying note 766 (Recommendation 5).

681. See supra note 536.

682. See supra text accompanying notes 556, 587.

683. See supra note 560 .

684. See infra text accompanying note 767 (Recommendation ๑).

685. See infra note 726 . 
substantial restructuring, along the lines suggested in this article, ${ }^{686}$ it is hard to accept that this can be possible.

As with any coinplex regulatory process designed to protect the public, there has to be soine tradeoff between the deinands of fairness and efficiency. This involves a fundamental policy judgment that in the present context, given the scale of thrift hquidations and the size, range and variety of creditor claims involved, is one of national import. It is a judgment that should be inade by the originator of the deposit protection system itself, in other words, Congress. Hence the evaluation that follows in this article, and the recommendations for improvement to the existing arrangeinents, are based on the assumption that Congress actually would expressly decide to authorize an administrative claims adjudication process.

\section{A. Fairness and Flexibility.}

The Hudspeth procedures are partly intended to assist the receiver in maintaining a degree of flexibility when processing claims. Indeed, section 1729(d) seems clearly to envisage this goal where it refers to "settling, coinpromising, or releasing" claims. Hence the FHLBB is anxious to ensure that the FSLIC Receiver has an opportumity to accommodate disputed clains before the parties confront each other in hitigation. In practice, many potentially coinplex claims are resolved at this level with a mininum of forinality and expense. ${ }^{687}$ The receiver also needs time to investigate the thrift's activities, many of which umght have been concealed froin the regulatory examiners before the thrift was seized. The thrift's records inight well be in disarray.

The FSLIC Receiver is carefully distingnished, both linguistically and institutionally, froin the FSLIC Corporate. Hence it is misleading to assuine that the FSLIC as insurer of deposits (and therefore as the major creditor in any receivership) is identical to the FSLIC Receiver itself. ${ }^{688}$ Nevertheless, the FSLIC Receiver still has the ordinary receivership responsibility of preserving the assets of the receivership for the optimal benefit of creditors. In practice the special representatives inust surely interact with policy formulators at the FSLIC Corporate in deciding whether, as the best overall strategy, to participate in a purchase and assumption transaction ${ }^{69}$ or to transfer insured accounts. ${ }^{690}$ The potential size of creditor clains inust inevitably weigh heavily in their deci-

686. See infra text accompanying notes 687-719.

687. Interview, supra note 275.

688. See supra text accompanying notes 196-98.

689. See supra text accompanying notes $189-95$.

690. See supra text accompanying note 193. 
sions. It is hard to accept, therefore, that the severe financial strictures under which the FSLIC as a whole has been placed, as a result of the depletion of its insurance fund and the escalation in administrative and hquidation costs, ${ }^{691}$ do not have a very strong influence when the FSLIC Receiver's Special Representatives make their decisions to accept or reject claims.

1. "Receiver's Determinations." It is just these forms of prior involveinent with the disputed claims that render the FSLIC Receiver virtually incapable of impartiality when it coines to adjudicating claims that remain in dispute after efforts to "settle" or "coinpromise" those claims have failed. To be sure, the mere fact that the FSLIC will inevitably fulfill the role of both creditor and receiver, if the agency is looked at as a unit, is not enough on its own to disqualify the FSLIC's appointment. ${ }^{692}$ But the question is one of degree, and the degree of conflict at the receivership level is, in the present financial crisis, unacceptably high. ${ }^{693}$

Indeed, the whole character of the Hudspeth rules themselves suggests that the receiver is conceived of as having a partisan role in the claims determination process. The fact that fee counsel perform services as and where needed by the Special Representatives, ${ }^{694}$ the fact that they provide confidential advice concerning claims to these representatives, ${ }^{695}$ and the fact that the Special Representative is expressly charged to take "cost savings" into account in the selection of the persons assigned to review creditor clains, ${ }^{696}$ all suggest that at the receivership level the review of claims is likely to be partisan, often unsyinpathetic, and certainly not detached.

If genuine adjudication were to take place at the receivership level, the process could hardly be described as fair to creditors if they and the receiver had moved beyond an atmosphere of "settlement" and "compromise." This is recognized by the FHLBB, which has changed the description of the receiver's decisions from "final determinations" to "receivers' determinations." 697 The alternative terminology conveys inore accurately what really happens in claims determinations, where the

691. See supra text accompanying notes 76-88.

692. See, e.g., Womble v. Dixon, 585 F. Supp. 728, 733 (E.D. Va. 1983) (holding that the insufficiency of receivership funds to pay all claims did not constitute a sufficient conflict of interest to warrant removal of the FSLIC as receiver), aff'd in part and vacated in part, 752 F.2d 80 (4th Cir. 1984).

693. See supra text accompanying notes $621,629-32$ (discussing the due process test).

694. See supra text accompanying notes $248,261$.

695. See supra text accompanying notes $270-71$.

696. See supra text accompanying note 261 .

697. See supra note 275 . 
first real "adjudication" only takes place before the Adjudication Division itself. 698

It would be inuch inore compatible with the concept of independent adjudication and internal separation of powers to treat claims decisions at the receivership level not as a species of "adjudication," but as what they were probably always assumed to be, namely, the mere acceptance or rejection of claims, the validity of which is to be determined by an objective third party. This wonld help to reduce the importance of the conflicts of interest, real and perceived, under which the receiver labors. It would also liberate the receiver from the futile duty of trying to inamtain an impartial posture in the administration of the receivership. And it would permit the receiver to represent more unequivocally the interests of the receivership as a whole when called upon to engage in soine form of mandatory alternative dispute resolution ${ }^{699}$ or when opposing a creditor in a claims dispute before the Adjudication Division.

2. Administrative Adjudications ("Reviews"). The first real "adjudication" of creditors' claims takes place at the level of the Adjudication Division. ${ }^{700}$ This is also the first place at which significant institutional separation imght be assumed to take place, though even here there is extensive prior and contimuing involvement by staff of the Adjudication Division with the receivership team when a thrift is seized. ${ }^{701}$ The staff are warned to avoid discussing any details that imght bear directly upon individual claims, ${ }^{702}$ but there is hittle in the Hudspeth procedures that can prevent internal commumication between Adjudication Division staff and the adjudicator, ex parte contacts between the receiver's agents and the adjudicator, and pressure on the adjudicator from the Board itself, on the one hand, and from the Director, OFSLIC (froin whom the adjudicator has received the delegated power to adjudicate), on the other.

Perhaps a de facto Chinese wall has been created within the Adjudication Division. For administrative appeals, at least, ${ }^{703}$ the initial rever-

698. Interview, supra note 275.

699. See infra text accompanying notes 715-17.

700. See supra text accompanying notes 278-97.

701. See supra text accompanying notes 249-50.

702. In particular, the attention of the Division's staff is drawn to Baltimore Contractors, Inc. $v$. United States, 643 F.2d 729 (Ct. Cl. 1981). In Baltimore Contractors, the court held that the continuing involvement by the Architect of the Capitol and his staff with the House board and its members created the appearance of unfairness and the possibility of improper influence in connection with the board's adjudication of a dispute between the architect and a contractor.

703. Requests for expedited relief, see supra text accompanying notes $300-11$, have been granted in only $3 \%$ of the cases (i.e. 8 out of 304 cases, as of March 23, 1988). Letter from June O. Stewart to Lawrence A. Baxter (Mar. 23, 1988). One of the reasons given for this extremely low success rate 
sal rate of receiver determinations seems to suggest that this has occurred. At present half of those receivers' determinations that have been taken on appeal have been reversed. ${ }^{704}$ The decisions of the Adjudication Division are now also accumulating and are becoming available in Westlaw and LEXIS databases. ${ }^{705}$ This development should aid im providing consistent guidance to the various receiverships and in subjecting the claims decisions to public scrutiny. In itself, the publication of their decisions should help to promote objectivity on the part of the adjudicators.

Yet even if improper influences have not, as a matter of practice, been brought to bear, it would still be appropriate to institutionalize the adjudicators' independence by elevating the office to the status of an administrative law judge ${ }^{706}$ in order to provide the security of tenure and insulation from external pressures that those officers enjoy. ${ }^{707}$ This might require specific statutory authorization. ${ }^{708}$

The record presented to the adjudicator on appeal is also open to criticism. The receiver is required by the Adjudication Division to assume an adversarial role in the appellate proceedings, ${ }^{709}$ but there is nothing to suggest that the privileged and confidential advice that she receives from fee counsel, for example, does not find its way into the office of the appellate adjudicator. If there is a possibility of this occurring, then there is a danger of unfairness to the creditor-claimant-who will not be fully apprised of the information upon which the adjudication will be based. Similarly, while internal staff memos might be acceptable

is that creditors have only the cost of a postage stamp to lose in filing such requests; as a result a very high proportion of frivolous requests are filed. Interview, supra note 275.

704. That is, 43 out of 85 cases, as of March 23, 1988. Letter from June O. Stewart, supra note 703.

705. These databases were added in 1988.

706. A model for this proposal is the West Virginia statute governing the regulation of failing financial institutions, which contains comprehensive provisious for the determination by receivers of the claims of creditors. W. VA. CODE § 31A-7-13 (1988). A person adversely affected by the complete or partial rejection of a claim is entitled to a formal hearing before an independent, qualified hearing examiner appointed by the commissioner. Id. $\S \S 31 \mathrm{~A}-7-14,31 \mathrm{~A}-8-1$. After this remedy has been exhausted, the claimant may seek judicial review. Id. § 31A-8-2.

707. See 5 U.S.C. $\S \S 3105,3344,5372$ (1982) (procedures for appointing AIJs).

708. Although agencies are free to add to the procedural requiremeuts of the APA, see, e.g., Vermont Yankee Nuclear Power Corp. v. NRDC, 435 U.S. 519, 524 (1978), the Office of Personnel Management will only assign to the agency as many ALJs as "are necessary for proceedings required to be conducted in accordance with sections 556 and 557" of the APA. 5 U.S.C. $\$ 3105$. Since formal adjudication is not required by either the Home Owners' Loan Act or the National Housing Act, see supra text accompanying notes 489-97, it is likely that OPM would not approve the assignmeut of ALJs for Hudspeth purposes.

709. See supra text accoinpanying notes 284-311. 
where they emanate from the same level as the adjudicator, ${ }^{710}$ they surely constitute an improper influence where they emanate from an adviser to a party to the proceedings. The rules should therefore be drafted so as to ensure that only material disclosed in the record should form the basis of the decision on appeal.

On the other hand, it should be recognized that large numbers of creditor appeals can be, and have already been, resolved without full, trial-type, oral hearings. The written record is often a sufficient basis upon which to resolve the dispute. ${ }^{711}$ Hence it would seem unduly burdensome to imsist on the mvariable adoption of all the formal adjudication requirements provided for in the APA. ${ }^{712}$ A hybrid procedure, which would permit the administrative law judge (or perhaps a preliminary adjudication officer of lesser status) to make an initial, reviewable decision whether to order that the appeal be conducted on the basis of an oral, evidentiary hearing, seems appropriate. Such a "shortened" or "modified" procedure has loug been apphied at the Interstate Commerce Commission, where it appears to have successfully eliminated unnecessary formahty and expedited decisions involving siniple disputes. ${ }^{713}$ The Civil Aeronautics Board also successfully experimented with "expedited" procedures. ${ }^{714}$

Fimally, on many occasions disputes between creditors and receivers might better be resolved through alternative dispute resolution techniques (ADR). A great variety of such techniques is available, ranging from arbitration, through mediation, to conciliation, ${ }^{715}$ and many of these are already employed by federal agencies. ${ }^{716}$ Their adoption is

710. Cf. United Steelworkers v. Marshall, 647 F.2d 1189, 1210-16 (D.C. Cir.) (holding that there is no statutory basis in the APA for a separation-of-functions requirement in Occupational Safety and Health Administration rulemaking procedures, and that a staff advocate nced not isolate herself from others within her agency), cert. denied, 453 U.S. 913 (1981).

711. Interview, supra note 275.

712. See 5 U.S.C. $\$ \S 554-557$ (1982).

713. See Edles, The ICC Hearing Process: A Cost-Benefit Approach to Administrative Agency Alternative Dispute Resolution, 16 TRANSP. L.J. 99 (1987). Some consideration would have to be given to the criteria by which the preliminary decision is to be made. The "material issue of fact" criterion is not always easy to apply at the initial decision stage, but placing a threshold on appealable claims according to the amount at issue carries its own potential for arbitrariness.

714. See id. at 103. Yet another illustration of the apparently successful use of inulti-channel adjudicatory procedure is provided by recent developinents at the Commodity Futures Trading Commission, where the agency einploys three types of procedures for its reparations adjudications: voluntary, summary and formal. See Smythe, The Reparations Program of the Commodity Futures Trading Commission: Reducing Formality in Agency Adjudications, 2 ADMIN. L.J. 39, 56-60 (1988).

715. See, e.g., Harter, Points on a Continuum: Dispute Resolution Procedures and the Administrative Process, 1 ADMIN. L.J. 141, 144-45 (1987) (suggesting that full range of ADR techniques be used to address the needs of the legislative process).

716. See Riggs \& Dorminey, Federal Agencies' Use of Alternative Means of Dispute Resolution, 1 ADMIN. L.J. 125, 137 (1987). 
strongly advocated by the Administrative Conference as a means of expediting agency proceedings and reducing costs. ${ }^{717}$ The receiver's powers under section 1729(d) are quite capable of accommodating ADR.

As argued in the previous section, ${ }^{718}$ however, the receiver really holds the posture of a committed party and for ADR to work where attempts to "settle, compromise, or release" claims have already failed, it would have to be imposed by a superior authority. The adjudicator in the Adjudication Division would be well-placed to choose between arbitration or mediation, for example. ${ }^{719}$ The rules should be drafted so as to create the power to appoint an arbitrator, for example, and to order that the receiver and claimant engage in compulsory arbitration, if such is the most appropriate means of ADR.

\section{B. Efficiency and Cost.}

The main motivation for developing the Hudspeth procedures has been to save costs and expedite the determination of creditor claims. ${ }^{720}$ Not only is this made possible by the informality of the claims processing procedure, in which the receiver is able to "settle, comproinise, or release claims," 721 but the adjudicatory procedure before the Adjudication Division of the Office of General Counsel at the FHLBB is also thought to be potentially quicker and less expensive than de novo judicial proceedings. Does the Hudspeth process fulfill this promise?

1. The Receivership Level. An embarrassment to the agencies' claim that FHLBB adjudication expedites claims determination is the progress of the Hudspeth case itself since the Fifth Circuit's decision. The court of appeals issued its final opinion on May 23, 1985, redirecting Hudspeth's claims "to the administrative track." Yet almost three years later Hudspeth had not been granted a receiver's determination of his claim. ${ }^{722}$ It was only after approaching his local Congressman that Hudspeth's attorney received any formal response to Hudspeth's request for a

717. Administrative Conference of the U.S., Agencies' Use of Alternative Means of Dispute Resolution, Recommendation No. 86-3, 1 C.F.R. $\$ 305,86-3$ (1988). See generally $A$ Colloguium on Improving Dispute Resolution: Options for the Federal Government, 1 ADMIN. L.J. 399 (1987) (sponsored by the Administrative Conference).

718. See supra text accompanying notes 692-99.

719. The Director of the Adjudication Division is hospitable to the idea of using ADR. Interview, supra note 275 .

720. See supra text accompanying note 92; see also Felt, FSLIC Receivership Claims Procedure, in ALI-ABA, FAILING FinANCIAL INSTITUtions 529, 531-34 (1987) (study materials).

721. 12 U.S.C $\$ 1729$ (d) (1982).

722. See supra text accompanying notes 273-77 (discussing "receiver's determinations"). 
determination of his claim. ${ }^{723}$ This came in the form of a proposed imitial determination, dated December 24, 1987, denying his claims. Since Hudspeth's attorney has requested reconsideration, the matter has not even reached the Board, or "appellate," stage. Hudspeth's attorney estimates that the original proceedings in chancery court and any possible appeal "would surely have reached resolution long before 1988"! 724

If the Hudspeth case itself were to be taken as a guide to the speed and efficiency of the Hudspeth process, the agencies' arguments would not be cogent at all. On the other hand, the FHLBB was really only in a position freely to develop its procedures after its authority to do so was recognized in Hudspeth. Hence the case might merely be an unfortunate exception. Nevertheless, although statistical information is difficnlt to compile ${ }^{725}$ and not necessarily even available, 726 there do seem to have been some considerable delays at the receivership level, ${ }^{727}$ at least in the

723. Telephone interview, supra note 107. The details are now more fully documented in Hudspeth's amicus brief in the Coit case. See Brief Amicus Curiae of Joseph M. Hudspeth in Support of Petitioner, Coit Independence Joint Venture v. FSLIC, 108 S. Ct. 1105 (1987) (No. 87-999); see supra note 18.

724. Brief Amicus Curiae of Joseph M. Hudspeth at 4 n.2. As this article went to press, the author was advised that the FSLIC had settled Hudspeth's claim. Telephone interview with Wylene W. Dunbar, counsel for Hudspeth (Aug. 18, 1988). It should also be noted that the claims in the Morrison-Knudsen group of cases have now been settled. Telephone interview, supra note 390.

725. Statistics are not easy to compile, partly because the performance of claims processors varies from region to region, Telephone interview, supra note 202, and partly because aggregate statistics do not reflect what happens in individual cases.

726. While I have experienced generous assistance from the Adjudication Division of the Office of General Counsel, FHLBB, it appears that there is in some quarters of the agency a predilection for secrecy. For example, an attempt by one attorney to use the Frcedom of Information Act to compile statistics from information concerning the claims processed in specific receiverships was foiled because the FHLBB adopted the view that such information is not subject to disclosure under the FOIA, creditor claims being "against the receiver, not the FSLIC." Letter from Ella P. Allen to Sarah H. Comley (Apr. 8, 1988). The agencies' position in this regard sits somewhat awkwardly with the FSLIC's argument that, as receiver, it enjoys sovereign immunity. See supra note 148. Its legality is also debatable. Cf. Rocap v. Indiek, 539 F.2d 174, 175-76 (D.C. Cir. 1976) (Federal Home Loan Mortgage Corporation subject to disclosure requirements even though it is self-financing). The "governmental control" of the FSLIC, whether FSLIC Corporate or FSLIC Receiver, is surely even greater.

This refusal to disclose information concerning receiverships appears to be maintained even in the face of requests from congressioual committees. See STAFF OF House Comm. on Banking, Finance \& Urban AfFairs, 100Th Cong., 2D Sess., Federal Asset Disposition AssociaTION: Report of aN INQuiry into its Operations and Performance ch. XI (Comm. Print 1988), reprinted in 134 CONG. ReC. H2228-30 (daily ed. Apr. 21, 1988).

727. Some of the attorneys $I$ interviewed complained of indordinate delays in receiving responses from receivers. $C f$. Memorandum of Law of Third-Party Defendants at 33, FSLIC v. Greenbaum, No. L-070020-87 (N.J. Super. Ct. 1988). This memorandum of law asserts that delays in the administrative process "can be extraordinary." It then cites W-V Enters. v. FSLIC, 234 Kan. 354, 673 P.2d 1112 (1983), as a case in which the FSLIC commenced an interpleader action to enjoin enforcement of a judgment and attachment order against a thrift in receivership two years after the Kansas Supreme Court had affirmed the judgment against the FSLIC as receiver. 
processing of contentious claims. ${ }^{728}$ One probable source of this delay is the failure to subject receiver's agents, at some points in the process, to rigid time limits. ${ }^{729}$ This should be remedied. ${ }^{730}$

2. The Board Level. At the Board level it appears that the process is becoming more expeditious. As of March 23, 1988, the Adjudication Division had received 129 administrative appeals, 85 of which it had completed. ${ }^{731}$ Almost half of these were completed in four weeks or less. ${ }^{732}$ It might be reasonable to assume, therefore, that as a general rule the speed and informality of the adjudicative process, once fully implemented and staffed, would render the determination of claims less expensive and more efficient than it might be if the agencies had to rely on the courts. Agency staff imsist that this is the case. ${ }^{733}$

3. Previously Adjudicated Claims. Considerations of efficiency and cost do not, however, justify the agencies' attempts to avoid the effects of judgments already entered against thrifts prior to their being placed in receivership. ${ }^{734}$ The agencies' view that preexisting but unappealed or unexecuted judgments should be vacated is dictated by their behef that section 1464(d)(6)(C) necessarily strips the courts of jurisdiction. ${ }^{735}$ As has been argued, however, this view of section 1464(d)(6)(C) is wrong. ${ }^{736}$ In any event, the agencies' position raises very serious article III problems. ${ }^{737}$

Furthermore, the agencies' view could also place a potential hitigant in a hopeless position. For example, in Homestead Savings v. Life Sav-

728. As to overall efficiency, the Southern Region, for example, has greatly improved the speed of its claims processing: in 1985, prior to the development of the Hudspeth procedures, the average length of time for processing a claim was 494.6 days; this time had dropped, in January 1988 , to 18.1 days. Telephone interview with Jndith L. Friedınan, Associate General Connsel, FHLBB (May 6, 1988). Yet this information can tell us little about nonroutine, contentious clains.

729. Cf. supra note 277.

730. See infra text accompanying notes 764-65 (Recommendation 4); $c f$. Admin. Conference of the U.S., Time Limits on Agency Actions, reprinted in 1 C.F.R. $§ 305.78-3$ (1988).

731. Letter from June 0 . Stewart, supra note 703.

732. Id.

733. See, e.g., Felt, supra note 720, at 533.

734. See supra notes 118-20; supra text accoinpanying notes 234-35.

735. Telephone interview, supra note 390 . An incidental argument is that a creditor with an adjudicated claim should still be required to resubmit the claim for fresh determination by the receiver, because if the receiver were obliged to accept the claim as valid this inight, at least psychologically, impede the settlement and negotiation process. Interview with David A. Felt, Assistant General Counsel, FHLBB, and Mark Gabrellian, Trial Attorney, FHLBB, in IVashington, D.C. (Oct. 22, 1987).

736. See supra text accompanying notes 394-403, 422-25.

737. See supra text accompanying note 589-99. 
ings \& Loan Association ${ }^{738}$ the plaintiff had been awarded a jury verdict against the defendant thrift of more than $\$ 6.2$ million, which amount had already been paid over to the clerk of the court. But the plaimtiff then found itself im a Catch-22 situation: because the verdict effectively pushed the defendant into insolvency, the defendant was placed into receivership by the FHLBB, and the FSLIC Receiver moved that the court vacate the judgment and relinquish jurisdiction. The motion was demied. As Judge Roszkowski observed:

Accepting the FSLIC's argument [that the judgment should be vacated] would put plaintiffs like Homestead in an untenable position. With the defendant savimgs and loan in a shaky position, a verdict for the plaintiff would probably press the defendant into receivership. Of course, the plaintiff could not pursue its administrative remedy until it had actually forced the defendant into receivership. The plaintiff goimg to trial either would get a soon-to-be-invalid verdict, a receiver, and a de novo tour through administrative proceedings or the plaintiff would get a defendant's verdict that would likely remam valid and res judicata. ${ }^{739}$

Such circumstances create a potential temptation for the FHLBB to use receivership appointınents as a means of denying hitigants their just claims.

It is also difficult to understand why the receiver's ability to settle or negotiate the claim would be impeded by recogmition of previous judgments. Once the thrift is placed in receivership, section 1464(d)(6)(C) effectively prevents the creditor from executing his judgment. He has no choice but to take into account the same strategic considerations as any other creditor with a valid claim. And the appellate process, even if incomplete, is unlikely to be more time-consuming or costly than readjudication of the claim by the receiver.

\section{Judicial Review.}

The jurisprudence relating to the nondelegation doctrine, 740 article III, ${ }^{741}$ and possibly even due process, ${ }^{742}$ dictates that there should be meaningful judicial review of the adjudicator's and the FHLBB's final

738. 668 F. Supp. 1121 (N.D. I1l. 1987) (opinion vacated and renoved from bound volunie, but appears in West's advance sheets). In terms of a settlement order, see No. 86 C 20268 (Dec. 2, 1987), the FSLIC, as receiver for Life Savings and Loan Association, agreed to acquiesce in the order of the court and forgo all post-trial notions and appeals on the condition that the plaintiff stipulate to the vacating of the judge's opinion. Conscquently, West Publishnig withdrew from its final volume the original opinion issued by the court. Telephone interview with Jeffrey H. Hornstein, counsel for Honestead (May 2, 1988).

739. 668 F. Supp. at 1123.

740. See supra text accompanying note 520-37.

741. See supra text acconupanying note $538-88$.

742. See supra text accompanying note 601-37. 
decisions. In view of the ambiguity created by section $1464(d)(6)(C),{ }^{743}$ clear provision for judicial review should be made by Congress when clarifying the FHLBB's statutory powers. ${ }^{744}$

The value of judicial review, even under the "arbitrary and capricious" standard, ${ }^{745}$ will depend on the quality of the record before the court, ${ }^{746}$ so the exhortations made earher ${ }^{747}$ are relevant in this context as well. It is suggested, however, that the "substantial evidence" standard of review is inerited in the case of creditor claims. The reason is that the determination of the validity and amount of creditor claims is likely to involve "adjudicative facts," as opposed to "legislative facts,"748 inasinuch as the specific details of thrift/creditor transactions will be in issue, rather than more general questions of thrift regulatory policy. Hence it seems appropriate that the reviewing court should be able to evaluate the adjudicator's decision according to the evidence presented in the adjudication record. If proper recordkeeping procedures are observed, there is no reason why the agency could not accommodate this standard of review.

As review will take place with the benefit of a full record, jurisdiction to review should, in accordance with the recommendation of the Administrative Conference, be placed in the courts of appeals. ${ }^{749}$

\section{Procedural Rules.}

With the creation of a restructured claims adjudicatory process there arises the need for the implementation of detailed procedural rules. These are best devised by the agency, using a notice and comment rulemaking process. ${ }^{750}$ In the hight of past experience, ${ }^{751}$ the FHLBB

743. See supra text accompanying notes $394-403$.

744. See infra text accompanying note 767 (Recommendation 6).

745. See supra text accompanying notes $498-509$.

746. See, e.g., Home Box Office, Inc. v. FCC, 567 F.2d 9, 54 (D.C. Cir.), cert. denied, 434 U.S. 829 (1977) (emphasizing the importance of a coherent record, even in informal rulemaking proceedings, to meaningful judicial review); see also 1 C.F.R. § 305.77-3 (1988).

747. See supra text accompanying notes 709-10.

748. See 2 K. Davis, AdMinistrative LaW TREatise $\S 12.3$ (1979) (discussing the distinction between adjudicative and legislative facts).

749. See Admiu. Conference of the U.S., The Choice of Forum for Judicial Review of Administrative Action, reprinted in 1 C.F.R. \$ 305.75-3 (1988).

750. Because they deal with "procedure" and not substance, there may be doubt whether such rules must be published in the Federal Register in accordance with $\S 553$ (d) of the APA. See 5 U.S.C. $\S 553(\mathrm{~b})(\mathrm{A})$ (1982). Even if publication is not required by the APA, the FHLBB could justifiably be criticized if it failed to publish the rules when so many creditors are affected. Dealing with interpretive rules and statements of general policy, the Administrative Conference has recommended that agencies voluntarily publish any rules that are "likely to have substantial impact on the public." See Admin. Conference of the U.S., reprinted in 1 C.F.R. § 305.76-5 (1988). One commentator has already noted the relevance of this recommendation to the procedures adopted by the FHLBB. See 
should be particularly sensitive to the need for adequate public consultation and guidance on the administration of its adjudications.

If Congress were to create a claims adjudication process, or if the Court were in Coit to declare that the authority to do so already exists, the FHLBB should expeditiously set about the task of devising appropriate rules that incorporate the structural suggestions as well as the time and jurisdictional limitations urged in the preceding sections of this article. ${ }^{752}$ In addition, the rules would have to be considerably inore coinplex than those contained in the Interim and Supplemental Rules. ${ }^{753}$ As presently formulated, these make no provision for the consolidation of claims, joinder of third parties and counterclaims, or for ineaningful discovery and subpoenas (to give a few examples). Given the complex nature of inost of the disputes that have already arisen in the reported cases, it is hard to imagine how the FHLBB could adjudicate such claims efficiently without these devices. In any event, the requirements of procedural due process would seem to dictate the provision of at least some facilities whereby parties may adequately establish their claims and challenge adverse evidence.

\section{CONCLUSIONS}

In this article it has been argued that legislation upon which the FHLBB and the FSLIC rely for the Hudspeth scheme is very dubious, not only because of the vagueness and ambiguity of the statutory language concerned, but also because vague statutory authority is insuffcient in the face of the numerous constitutional concerns that are raised by the Hudspeth scheme as it is presently constrncted. I have also tried to show, however, that if Congress were to act unambiguously, it could establish an administrative claims adjudication scheme that would survive constitutional challenge. To achieve this objective, Congress and the FHLBB would have to institute a number of safeguards designed to provide the protections mandated by the Constitution. These safeguards are encapsulated in the following recommendations.

Pfeiler, supra note 54, at 461 n.102. In any event, to the extent that the rules might deal with such matters as the ranking of claims, see supra note 195, they would clearly have to be published in accordance with the APA's notice and comment procedures.

751. During the preparation of this article as a report for the Administrative Conference, the author encountered numerous complaints regarding the availability of, and reluctance on the part of the FHLBB to finalize, the procedural rules governing the Hudspeth claims process. The FHLBB has proven responsive to these complaints: it has published interim rules and supplemental proposed rules, and has virtually finalized its present procedures. See supra text accompanying notes 200-05.

752. The rules presently devised by the FHLBB fail to address any of the concerns expressed in the recommendations presented in this article.

753. See supra text accompanying notes $253-69$. 


\section{A. Recommendations.}

1. Acquisition of Statutory Authority for Claims Adjudication. While the FHLBB might have statutory authority under section 1464 (d)(11) to create a claims adjudication system, ${ }^{754}$ if such is the intention of Congress, it should be stated in express terms. This is necessary for two reasons. First, notwithstanding the deference ordinarily shown by courts to the construction by agencies of their statutory mandates, 755 vague statutory powers are interpreted restrictively where they infrimge on constitutional rights. ${ }^{756}$ Secondly, in accepting deviations from the article III adjudicative model, the Supreme Court has relied partly on the fact that Congress has expressed a clearly stated legislative purpose to depart from the model. 757 This rehance seems particularly apposite in the present context since, unlike the situation with receivership powers, Congress, when it has directly addressed the issue of administrative adjudication, has always prescribed fairly detailed procedural rules. ${ }^{758}$

To clarify the situation, the FHLBB should seek direct authority for an administrative claims adjudication process. While Congress need not go so far as to specify the detailed procedures, Congress should make a basic policy decision as to whether an administrative adjudication process is preferable to the regular judicial process. If Congress does reach such a conclusion, it should act to create adjudicative authority and an adjudicative process, clearly and unambiguously, and along the following lines.

2. Formalization of the Adjudicative Process. In order to meet due process and article III concerns of impartiality and fairness, ${ }^{759}$ Congress should establish a bifurcated process for adjudicating claims. Where hearings are required to resolve matters in dispute, administrative law judges should adjudicate. The necessary authority to engage administrative law judges should be granted by Congress. ${ }^{760}$ Where claims can be resolved on the basis of written documentation alone, the FHLBB should be permitted to use simplified, less formal procedures, independent of the receiver but not necessarily involving administrative law judges. ${ }^{761}$

754. See supra text accompanying notes 427-29.

755. See supra text accompanying notes $325-36$.

756. See supra text accompanying notes 129-31.

757. See supra text accompanying notes 596-98.

758. See supra text accompanying notes $393,401-03$.

759. See supra text accompanying notes 671-75.

760. See supra text accompanying note 708.

761. See supra text accompanying notes 711-14. 
The statutory scheme should make it clear that receivers do not "adjudicate" claims, and the rules should treat receivers as parties who are on equal terms with claimants. ${ }^{762}$

3. Procedures for Alternative Dispute Resolution. In order to avoid unnecessary formality and delay, administrative law judges should be empowered to order that parties (imcluding receivers) engage in Alternative Dispute Resolution where this is appropriate. ${ }^{763}$

4. Procedural Rules. Once the claims adjudications process has been authorized, the FHLBB should engage in a notice-and-comment rulemaking procedure, setting forth coinprehensive and adequate rules of practice for claims adjudication. ${ }^{764}$

A probable source of delay in receivership determinations is the failure to subject receivers to fixed time limitations. ${ }^{765}$ The FHLBB's final rules should provide for strict, albeit reasonable, time limits that are applicable not only to claimants but also to receivers and their agents.

5. Jurisdiction over Claims Already Adjudicated in Court. In order to avoid agency aggrandizement at the expense of article III courts, and in order to prevent the temptation to use receivership decisions as a strategic device to the detriment of the creditors of thrifts, the FHLBB and the FSLIC Receiver shonld not be permitted to override judgments already given by federal and state courts, whether or not these remain appealable. ${ }^{766}$ The agencies' power to determine claims should not encompass judgments in favor of creditors if such judgments have already been entered by a court of competent jurisdiction before thrifts have been placed in receivership. The FSLIC Receiver should either acquiesce in these judgments or pursue its ordinary post-trial remedies.

6. Judicial Review. Congress should make adequate provision for judicial review of claims decisions by the FHLBB. ${ }^{767}$ To this end, Congress should specify that the courts of appeals have review jurisdiction and that the "substantial evidence" standard should apply.

762. See supra text accompanying notes 692-99.

763. See supra text accompanying notes 715-19.

764. See supra text accompanying notes 750-53.

765. See supra text accompanying notes 722-30.

766. See supra text accompanying notes 734-39.

767. See supra text accompanying notes 740-49. 


\section{B. General Observations.}

It is important to conclude with a reminder of the limited scope of this article. The resolution of creditors claims in receiverships takes place within a much broader context that is itself controversial, or potentially so. No atteinpt has been made here, for example, to examine the underlying causes of thrift failure and whether the problems that have led to the adoption of the Hudspeth doctrine might be obviated altogether by a different system of thrift regulation.768

Also beyond the scope of this article is the question of the discretionary power exercised by the FHLBB and the FSLIC in determining whether to place a thrift in receivership and, once this has been done, whether to hquidate its assets or transfer the assets and liabilities to another thrift. As was noted earlier, the FHLBB and the FSLIC exercise an enormous amount of discretion, both when the FHLBB decides to appoint a receiver and when the FSLIC Receiver decides whether to engage in some form of purchase and assumption transaction or to liquidate the assets of the receivership. These agency decisions have a inajor impact on the rights of creditors. In the case of a partial purchase and assumption transaction, for example, a creditor might quite arbitrarily be omitted from the benefits of the transfer of assets and liabilities. ${ }^{769}$ These decisions are, of course, heavily laden with questions of policy, and so they are not easily susceptible to codification. ${ }^{770}$ Nevertleeless, their significance strongly suggests that thought should be given to the means by which creditors might be protected, ${ }^{771}$ whether in the courts ${ }^{772}$ or per-

768. For a discussion of suggested reform in bank regulation, see J. Macey \& G. Miller, Bank Failures, Risk Monitoring, and the Market for Bank Control (1988) (draft report to the ACUS); see also supra note 24.

769. See supra text acconupanying notes 194-95. In addition to affecting the procedural rights of creditors and their prospects of fully recovering their claims, the decision to subject creditors to the Hudspeth procedures may have a direct impact on the substantive rights themselves. For example, the rights of parties to loan agreenents may be significantly affected if these rights are determined by Hudspeth adjudicators. See Pfeiler, supra note 54, at 448-57.

770. Cf. Getty v. FSLIC, 805 F.2d 1050, 1054 (D.C. Cir. 1986). Considering pre-receivership action by the FSLIC, the Getty court said, "Congress recognized that in authorizing acquisition of distressed institutions FSLIC would need absolute discretion in sone areas, e.g., determining who is qualified to bid . . . and calculating the cost of the bids." Id.

771. Sonie atteution has been given to protecting the rights of the officers of thrifts. See, eg., Malloy, Adjudication Practices and Procedures of the Federal Bank Regulatory Agencies, in 2 ADMINISTRATIVE CONFERENCE OF THE UNITED STATES: RECOMMENDATIONS AND REPORTS 1215, 1332-34 (1987) (recommending greater publicity of adjudications to help guide the officers of thrifts); Student Project: Savings and Loan Insolvency in the '80's, 15 AKRON L. REv. 441 (1982). The position of creditors has, however, been ignored.

772. Cf. Getty, 805 F.2d at 1057-62 (applying an "arbitrary and capricious" standard in setting aside award to competing bidder); Hartigan y. FHLBB, 746 F.2d 1300, 1310 (7th Cir. 1984) (reviewing FSLIC's calculation of cost of bids to ensure consistent apphication of economic nuethodology). 
haps through the use of guidelines. ${ }^{773}$

773. The FDIC, for example, has published guidelines indicating when it will provide financial assistance to a failing bank. See Statement of Policy and Criteria on Assistance to Operating Insured Banks, 51 Fed. Reg. 44,122 (1986). As this article went to press the FHLBB published soine guidelines with a similar purpose. See supra note 151. 